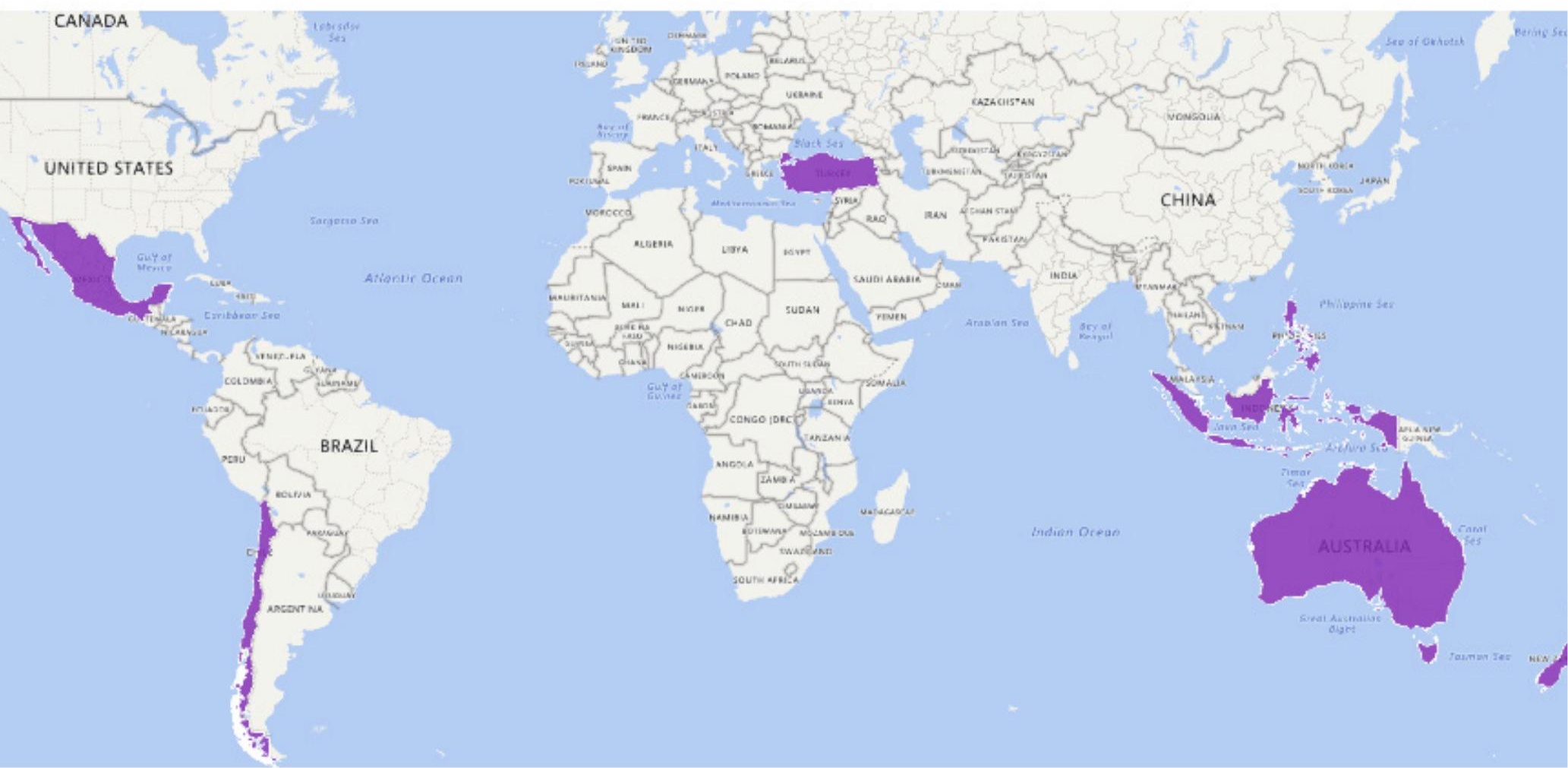

Animal welfare regulations and practices in 7 (potential) trade-agreement partners of the EU with a focus on laying hens, broilers and pigs

Mexico, Chile, Indonesia, Australia, New Zealand, Turkey and the Philippines

Marc B.M. Bracke, Herman M. Vermeer and Rick A. van Emous

REPORT 1160

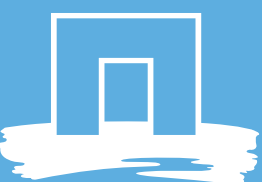

WAEENINGEN

UNIVERSITY \& RESEARᄃH 



\section{Animal welfare regulations and practices in 7 (potential) trade-agreement partners of the EU with a focus on laying hens, broilers and pigs}

Mexico, Chile, Indonesia, Australia, New Zealand, Turkey and the Philippines

Marc B.M. Bracke, Herman M. Vermeer and Rick A. van Emous

This research was conducted by Wageningen Livestock Research, commissioned and funded by the Ministry of Agriculture, Nature and Food Quality, within the framework of Policy Support Research theme 'Animal Health and Welfare' (project number BO-43-013.02-006)

Wageningen Livestock Research

Wageningen, May 2019

Report 1160 
Bracke, M.B.M., H.M. Vermeer, R.A. van Emous, 2019. Animal welfare regulations and practices in 7 (potential) trade-agreement partners of the EU with a focus on laying hens, broilers and pigs; Mexico, Chile, Indonesia, Australia, New Zealand, Turkey and the Philippines. Wageningen Livestock Research, Report 1160.

Samenvatting NL Dieren: welzijnsregelgeving en praktijken in 7 potentiële handelspartners van de EU: Mexico, Chili, Indonesië, Australië, Nieuw-Zeeland, Turkije en de Filipijnen, met nadruk op leghennen, vleeskuikens en varkens.

Summary UK Animal: welfare regulations and practices in 7 (potential) trade-agreement partners of the EU: Mexico, Chile, Indonesia, Australia, New Zealand, Turkey and the Philippines, with a focus on laying hens, broilers and pigs.

This report can be downloaded for free at https://doi.org/10.18174/475497 or at www.wur.nl/livestock-research (under Wageningen Livestock Research publications).

(C) 2019 Wageningen Livestock Research

P.O. Box 338, 6700 AH Wageningen, The Netherlands, T +31 (0)317 483953 ,

E info.livestockresearch@wur.nl, www.wur.nl/livestock-research. Wageningen Livestock Research is part of Wageningen University \& Research.

All rights reserved. No part of this publication may be reproduced and/or made public, whether by print, photocopy, microfilm or any other means, without the prior permission of the publisher or author.

Wageningen Livestock Research is NEN-EN-ISO 9001:2015 certified.

All our research commissions are in line with the Terms and Conditions of the Animal Sciences Group. These are filed with the District Court of Zwolle.

Wageningen Livestock Research Report 1160 


\section{Table of contents}

$\begin{array}{lr}\text { Abbreviations } & 7\end{array}$

1

Introduction

1.1 References

2

Across countries

11

2.1 Production and trade

2.2 Animal welfare generally

2.3 References

3.1 Introduction

3.2 Animal welfare generally

3.3 Layers

3.3.1 Production and trade 16

$\begin{array}{ll}3.3 .2 \text { Welfare regulations } & 16\end{array}$

3.3.3 Practical conditions 16

$\begin{array}{ll}3.3 .4 \text { Trends } & 17\end{array}$

$\begin{array}{lll}3.4 & \text { Broilers } & 17\end{array}$

3.4.1 Production and trade $\quad 17$

$\begin{array}{ll}3.4 .2 \text { Welfare regulations } & 17\end{array}$

3.4.3 Practical conditions 17

$\begin{array}{ll}3.4 .4 \text { Trends } & 17\end{array}$

$\begin{array}{lll}3.5 & \text { Pigs } & 17\end{array}$

3.5.1 Production and trade 17

$\begin{array}{ll}3.5 .2 \text { Welfare regulations } & 18\end{array}$

$\begin{array}{ll}3.5 .3 \text { Practical conditions } & 18\end{array}$

$\begin{array}{ll}3.5 .4 \text { Trends } & 18\end{array}$

$\begin{array}{llr}3.6 & \text { References } & 18\end{array}$

4

$\begin{array}{ll}\text { Chile } & \mathbf{2 1}\end{array}$

$\begin{array}{lll}4.1 & \text { Introduction } & 21\end{array}$

4.2 Production and trade generally $\quad 21$

$\begin{array}{lll}4.3 & \text { Animal welfare generally } & 21\end{array}$

$\begin{array}{lll}4.4 & \text { Layers } & 22\end{array}$

4.4.1 Production and trade $\quad 22$

$\begin{array}{ll}\text { 4.4.2 Welfare regulations } & 22\end{array}$

4.4.3 Practical conditions $\quad 22$

4.4.4 Trends $\quad 23$

$\begin{array}{lll}4.5 & \text { Broilers } & 23\end{array}$

4.5.1 Production and trade $\quad 23$

4.5.2 Welfare regulations 23

4.5.3 Practical conditions $\quad 23$

$\begin{array}{ll}4.5 .4 \text { Trends } & 23\end{array}$

$\begin{array}{lll}4.6 & \text { Pigs } & 23\end{array}$

4.6.1 Production and trade $\quad 23$

$\begin{array}{ll}\text { 4.6.2 Welfare regulations } & 24\end{array}$

4.6.3 Practical conditions $\quad 24$

$\begin{array}{ll}4.6 .4 \text { Trends } & 24\end{array}$ 
5.1 Introductie

$\begin{array}{lll}5.2 & \text { Production and trade generally } & 27\end{array}$

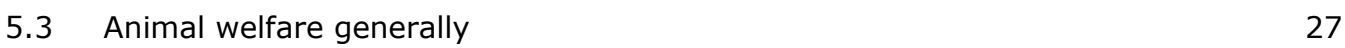

$\begin{array}{lll}5.4 & \text { Layers } & 28\end{array}$

5.4.1 Production and trade $\quad 28$

$\begin{array}{ll}5.4 .2 \text { Welfare regulations } & 29\end{array}$

5.4.3 Practical conditions $\quad 29$

5.4.4 Trends $\quad 29$

5.5 Broilers $\quad 29$

5.5.1 Production and trade 29

$\begin{array}{ll}5.5 .2 \text { Welfare regulations } & 29\end{array}$

$\begin{array}{ll}5.5 .3 \text { Practical conditions } & 30\end{array}$

5.5.4 Trends $\quad 32$

$\begin{array}{lll}5.6 & \text { Pigs } & 33\end{array}$

5.6.1 Production and trade $\quad 33$

$\begin{array}{ll}\text { 5.6.2 Welfare regulations } & 33\end{array}$

5.6.3 Practical conditions 33

$\begin{array}{ll}5.6 .4 \text { Trends } & 34\end{array}$

$\begin{array}{lll}5.7 & \text { References } & 34\end{array}$

6.1 Introduction

$\begin{array}{lll}6.2 & \text { Production and trade generally } & 38\end{array}$

$\begin{array}{lll}6.3 & \text { Animal welfare generally } & 38\end{array}$

$\begin{array}{lll}6.4 & \text { Layers } & 39\end{array}$

6.4.1 Production and trade $\quad 39$

6.4.2 Welfare regulations $\quad 40$

6.4.3 Practical conditions $\quad 40$

6.4.4 Trends $\quad 41$

$\begin{array}{lll}6.5 & \text { Broilers } & 41\end{array}$

6.5.1 Production and trade $\quad 41$

6.5.2 Welfare regulations $\quad 41$

6.5.3 Practical conditions $\quad 42$

$\begin{array}{ll}6.5 .4 \text { Trends } & 43\end{array}$

$\begin{array}{lll}6.6 & \text { Pigs } & 43\end{array}$

$\begin{array}{ll}\text { 6.6.1 Production and trade } & 43\end{array}$

$\begin{array}{ll}\text { 6.6.2 Welfare regulations } & 43\end{array}$

6.6.3 Practical conditions $\quad 44$

6.6.4 Trends $\quad 45$

$\begin{array}{lll}6.7 & \text { References } & 45\end{array}$

7.1 Introduction $\quad 49$

$\begin{array}{lll}7.2 & \text { Production and trade generally } & 49\end{array}$

$\begin{array}{lll}7.3 & \text { Animal welfare generally } & 49\end{array}$

7.4 Layers $\quad 52$

7.4.1 Production and trade $\quad 52$

7.4.2 Welfare regulations $\quad 52$

$\begin{array}{ll}7.4 .3 \text { Practical conditions } & 53\end{array}$

7.4.4 Trends $\quad 53$

$\begin{array}{lll}7.5 & \text { Broilers } & 53\end{array}$

7.5.1 Production and trade $\quad 53$

$\begin{array}{ll}\text { 7.5.2 Welfare regulations } & 53\end{array}$ 
7.6.1 Production and trade

7.6.2 Welfare regulations 55

7.6.3 Practical conditions $\quad 56$

$\begin{array}{ll}7.6 .4 \text { Trends } & 57\end{array}$

$\begin{array}{lll}7.7 & \text { References } & 57\end{array}$

8.1 Introduction

8.2 Production and trade generally

8.3 Animal welfare generally

8.4 Layers

8.4.1 Production and trade $\quad 62$

8.4.2 Welfare regulations $\quad 62$

8.4.3 Practical conditions $\quad 62$

8.4.4 Trends $\quad 62$

$\begin{array}{lll}8.5 & \text { Broilers } & 63\end{array}$

8.5.1 Production and trade 63

$\begin{array}{ll}\text { 8.5.2 Welfare regulations } & 63\end{array}$

$\begin{array}{ll}\text { 8.5.3 Practical conditions } & 63\end{array}$

$\begin{array}{ll}\text { 8.5.4 Trends } & 63\end{array}$

$\begin{array}{lll}8.6 & \text { Pigs } & 63\end{array}$

$\begin{array}{ll}\text { 8.6.1 Production and trade } & 63\end{array}$

$\begin{array}{lll}8.7 & \text { References } & 63\end{array}$

$9 \quad$ The Philippines $\quad 65$

$\begin{array}{lll}9.1 & \text { Introduction } & 65\end{array}$

9.2 Production and trade generally $\quad 65$

$\begin{array}{lll}9.3 & \text { Animal welfare generally } & 65\end{array}$

$\begin{array}{lll}9.4 & \text { Layers } & 66\end{array}$

9.4.1 Production and trade 66

9.4.2 Welfare regulations $\quad 66$

$\begin{array}{ll}9.4 .3 \text { Practical conditions } & 67\end{array}$

$\begin{array}{ll}9.4 .4 \text { Trends } & 67\end{array}$

$\begin{array}{lll}9.5 & \text { Broilers } & 68\end{array}$

9.5.1 Production and trade $\quad 68$

$\begin{array}{ll}\text { 9.5.2 Welfare regulations } & 68\end{array}$

9.5.3 Practical conditions 68

$\begin{array}{ll}9.5 .4 \text { Trends } & 68\end{array}$

$\begin{array}{lll}9.6 & \text { Pigs } & 68\end{array}$

9.6.1 Production and trade $\quad 68$

$\begin{array}{ll}\text { 9.6.2 Welfare regulations } & 69\end{array}$

$\begin{array}{ll}9.6 .3 \text { Practical conditions } & 70\end{array}$

$\begin{array}{ll}\text { 9.6.4 Trends } & 70\end{array}$

$\begin{array}{lll}9.7 & \text { References } & 70\end{array}$

$\begin{array}{lll}10.1 & \text { Invitation } & 74\end{array}$

$\begin{array}{ll}10.2 & \text { Introduction to the questionnaire }\end{array}$

$\begin{array}{ll}10.3 \text { Background information } & 75\end{array}$

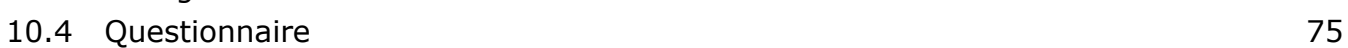




\title{
Abbreviations
}

\author{
AU: Australia \\ API: Animal Protection Index \\ CL: Chile \\ CWE: Carcass weight equivalent \\ EC: European commission \\ EU: European Union \\ FAO: Food and Agriculture Organisation \\ ID: Indonesia \\ MT: Metric tonne $(1000 \mathrm{~kg})$ \\ MX: Mexico \\ NL: The Netherlands \\ NZ: New Zealand \\ OIE: World Organisation for Animal Health (Office International des Epizooties) \\ $\mathrm{PH}$ : Philippines \\ TR: Turkey \\ VACI: Voiceless Animal Cruelty Index
}




\section{Introduction}

Trade agreements between the EU and countries outside the EU may give rise to animal welfare concerns, especially related to the import of products derived from animals with a lower welfare status in these countries compared to EU standards. In order to be able to better weigh such concerns an inventory of the animal welfare status in these countries, compared to the domestic EU situation was called for. In this respect it was considered particularly relevant to explore the welfare status of those farm animals for which the EU has adopted specific welfare regulations, namely pigs, broilers and layers, kept in those countries where trade agreements were being (re-)negotiated, i.e. Mexico (MX), Chile (CL), Indonesia (ID), Australia (AU), New Zealand (NZ), Turkey (TR) and the Philippines (PH). Previously, in 2007 and 2009, first inventories were made to describe animal welfare regulations as well as societal perceptions on a more global scale (Bracke, 2009). The current project aims to update the previous report by describing in particular the welfare status, i.e. regulations and production practices, of pigs, broilers and laying hens in the 7 aforementioned countries (see Figure 1).

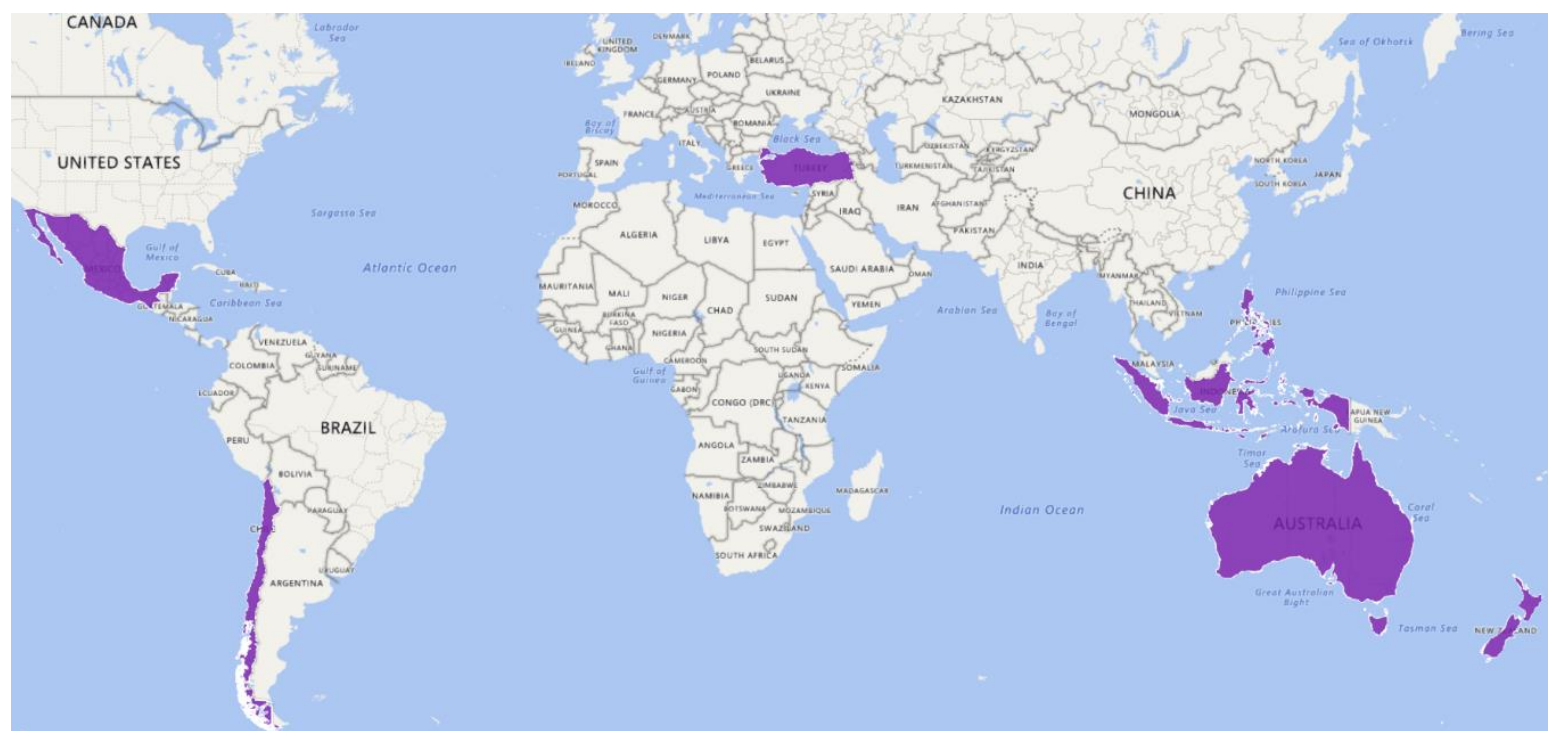

Figure 1. Geographical location of the 7 non-EU countries (Mexico (MX), Chile (CL), Indonesia (ID), Australia (AU), New Zealand (NZ), Turkey (TR) and the Philippines (PH)) for which the welfare status of esp. commercially-farmed pigs and chickens are described in this report.

The order of the countries listed represents the order in which data have been collected and the subreports were drafted. The chapter on Mexico (Chapter 3) dates largely from the end of 2017, while the other countries were screened mostly in 2018.

Information was collected from the internet (with a focus on pages in the English language) and, where possible, by contacting the Dutch Foreign Agricultural Services (DFAS) and a local expert, preferably an animal-welfare scientist, or a contact otherwise considered knowledgeable and willing to share information. Information from NGO's and industry were mainly collected by scanning websites and international pig and poultry magazines. A questionnaire was used to guide the knowledge elicitation from DFAS and expert contacts. The questionnaire (see Annex 1) focussed on regulations and practical conditions related to the welfare of intensively-farmed poultry (layers and broiler) and pigs, esp. as compared to the welfare requirements in the EU (see Annex 2 and Annex 1 - Background information), and future developments. The collection of information about the welfare of pigs has a reduced priority in the predominantly Muslim countries (Indonesia and Turkey). Most used search terms in internet searches were: poultry, chicken, layers, broilers, pigs, pork, welfare, [Country], regulations and legislation (in English). The main relevant findings have been incorporated in this report leaving original formulations largely intact, where appropriate, with the relevant reference at the end of each sub-section/paragraph. It may be noted also that much of the information in this report is derived from sources that may be disputed (e.g. from farmer magazines, farm and NGO representatives), and that it has not been possible to verify the obtained information reliability or in 
detail. To illustrate the disputability of information further we just want to refer to a recommended local university professor responding as follows to our request for information: "I think the person answering [your survey] should be not from the industry itself, nor from governmental bodies". As a consequence the main focus has been on reporting search results as they were found/encountered/presented, referenced as specifically as possible (at the end of each statement or paragraph, with a separate reference list following each chapter). We therefore also abstained from discussion and conclusion sections at report or chapter level. Two more reasons for this were that our searches would inevitably be incomplete (e.g. because we often could not search in any detail in the local languages) and that it could be counterproductive to be judging third-country welfare from an EU perspective. One DFAS contact replied to our request that welfare information may help the country make progress, but that it was also sensitive to being told what to do. Therefore it might be better to present findings more factually (as they were found/obtained) and perhaps emphasise e.g. the relationship between economic progress and animal welfare. 'A happy cow produces more milk' (DFAS, Pers. comm.). The report therefore leaves the drawing of conclusions to the readers to decide for themselves based on the information presented here 'as is' (and thus despite the fact that in some cases such as data regarding production and trade was at times divergent and that are not always easy, sometimes impossible to explain, and hence left unanswered (as may also happen in our own country; e.g. regarding the numbers of pigs, RTL, 2019)).

The remainder of this report has 8 chapters, one for each of the 7 countries preceded by a chapter presenting data that apply 'Across countries'. The country-specific chapters have sections on production and trade, animal-welfare generally, as well as sections on each of the 3 types of animals (layers, broilers, pigs). The species-specific sections commonly have a specific section for that type of animal on Production and trade, Welfare regulations, Practical conditions and Trends.

Welfare regulations, which primarily focus on welfare legislation, but also other welfare prescriptions (e.g. welfare schemes), and practical conditions were both considered relevant as these may not always be in line. We know this to be an issue even in the EU. The EU has some of the world's highest animal welfare standards, but EU actions to improve animal welfare, while successful in some areas, show delays in implementation and weaknesses that persist in certain areas related to welfare issues on the farm (notably routine tail docking of pigs), during transport (notably compliance with longdistance transport) and at slaughter (most notably concerning slaughter without stunning or with inadequate stunning; ECA, 2018). It was anticipated that such discrepancies may also exist in third countries (see for example the way pigs are being killed in China to eradicate ASF (African Swine Fever); Burgers, 2018; Roos, 2019). Discrepancies between regulations and practices may be more likely in third countries as compared to the EU where there is more public pressure, as EU citizens are increasingly concerned about the effects of farming on animal welfare, and the interrelated impact on public and animal health (ECA, 2018).

\subsection{References}

ECA (European Court of Auditors), 2018. Animal welfare in the EU: closing the gap between ambitious goals and practical implementation. Special report. European Court of Auditors. Available at https://www.eca.europa.eu/Lists/ECADocuments/SR18_31/SR_ANIMAL_WELFARE_EN.pdf. Accessed 5-12-2018.

Burgers, R., 2018. Europarlementariërs gaan vragen stellen over schokkende Chinese ruimingsvideo. [Members of the European Parliament ask questions about shocking Chinese eradication video.] Pig Business. Nov. 27, 2018. Available at https://www.pigbusiness.nl/artikel/148084europarlementariers-gaan-vragen-stellen-over-schokkende-chinese-ruimingsvideo/. Accessed 281-2019.

Roos, T., 2019. China stopt varkens levend onder de grond. [China puts pigs under the soil alive.] Reformatorisch Dagblad. Jan. 25, 2019.

RTL, 2019. Miljoenen varkens meer gefokt in Nederland dan toegestaan. [Millions of pigs more raised in the Netherlands than allowed.] RTL Nieuws. Jan. 22, 2019. Available at https://www.rtlnieuws.nl/nieuws/nederland/artikel/4582861/miljoenen-varkens-meer-gefokt-danofficieel-bekend. Accessed 28-1-2019. 


\section{Across countries}

This chapter describes relevant information of sources that allow a comparison across countries.

\section{$2.1 \quad$ Production and trade}

The tables below show production and trade data as obtained from the USDA (Tables 1 and 2), Indexmundi (Table 3) and the International Egg Commission (Table 3; Windhorst, 2018).

Table 1. Data on the production, consumption and trade of pigs in listed countries (data shown concern 2016).

\begin{tabular}{|c|c|c|c|c|c|c|c|c|}
\hline Country & $\begin{array}{l}\text { Pig numbers } \\
\text { production } \\
\text { (1000 head) }\end{array}$ & $\begin{array}{l}\text { Imports } \\
(1000 \\
\text { head) }\end{array}$ & $\begin{array}{l}\text { Exports } \\
(1000 \\
\text { head) }\end{array}$ & $\begin{array}{l}\text { Total } \\
\text { slaughter } \\
\text { (1000 } \\
\text { head) }\end{array}$ & $\begin{array}{l}\text { Pig meat } \\
\text { production } \\
(1000 \mathrm{MT} \\
\text { CWE) }\end{array}$ & $\begin{array}{l}\text { Pig meat } \\
\text { imports } \\
(1000 \\
\text { MT CWE) }\end{array}$ & $\begin{array}{l}\text { Pig meat } \\
\text { exports } \\
(1000 \mathrm{MT} \\
\text { CWE) }\end{array}$ & $\begin{array}{l}\text { Pigs Domestic } \\
\text { consumption } \\
\text { (1000 MT } \\
\text { CWE) }\end{array}$ \\
\hline Mexico & 17.700 & 20 & 0 & 16.794 & 1.211 & 1.021 & 141 & 2.091 \\
\hline Chile & & & & & 508 & 76 & 173 & 411 \\
\hline Australia & 5.028 & 0 & 0 & 5.040 & 386 & 210 & 38 & 558 \\
\hline $\begin{array}{l}\text { New } \\
\text { Zealand }\end{array}$ & & & & & 45 & 62 & 0 & 107 \\
\hline Philippines & & & & & 1.540 & 195 & 1 & 1.734 \\
\hline
\end{tabular}

Source: USDA Foreign Agricultural Service, 2018. [Query done on 8-11-2018 to retrieve production and trade data from 2016.] Available at https://apps.fas.usda.gov/psdonline/app/index.html\#/app/advQuery. Accessed 8-11-2018. MT: metric tonnes $(1000 \mathrm{~kg})$; CWE: Carcass Weight Equivalent; the Muslim countries Indonesia and Turkey are not listed.

Table 2. Data on the production, consumption and trade of broilers in listed countries (data shown concern 2016).

\begin{tabular}{|c|c|c|c|c|}
\hline Country & $\begin{array}{l}\text { Broilers mean } \\
\text { production ( } 1000\end{array}$ & $\begin{array}{l}\text { Broiler meat } \\
\text { imports ( } 1000\end{array}$ & $\begin{array}{l}\text { Broiler meat } \\
\text { exports ( } 1000\end{array}$ & $\begin{array}{l}\text { Broilers Domestic } \\
\text { consumption ( } 1000\end{array}$ \\
\hline & MT) & MT) & MT) & MT) \\
\hline Mexico & 3.275 & 791 & 5 & 4.061 \\
\hline Chile & 622 & 130 & 106 & 646 \\
\hline Indonesia & 1.640 & 0 & 0 & 1.640 \\
\hline Australia & 1.164 & 12 & 30 & 1.146 \\
\hline Turkey & 1.900 & 0 & 296 & 1.604 \\
\hline Philippines & 1.210 & 244 & 4 & 1.450 \\
\hline
\end{tabular}

Source: USDA Foreign Agricultural Service, 2018. [Query done on 8-11-2018 to retrieve production and trade data from 2016.] Available at https://apps.fas.usda.gov/psdonline/app/index.html\#/app/advQuery. Accessed 8-11-2018. Note: Chicken meat production (not shown here) is a bit higher as it involves also slaughter of laying hens. Broiler production data on New Zealand are not available from this source. 
Table 3 shows data obtained from the indexmundi.com website.

Table 3. Production and trade data for broilers and pigs in listed countries from the indexmundi.com website.

\begin{tabular}{|c|c|c|c|c|c|c|c|c|c|c|}
\hline$\frac{8}{2}$ & 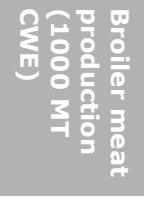 & $\frac{\text { ๑ }}{\frac{0}{\mathrm{~g}}}$ & 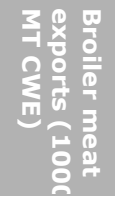 & 羿 & 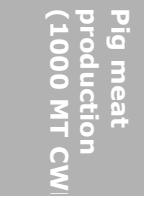 & 률 & 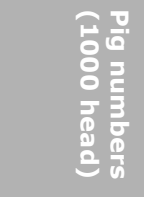 & 롤 & 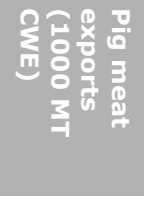 & \\
\hline $\begin{array}{l}\text { Largest in } \\
\text { the world }\end{array}$ & 19.004 & 1 (US) & 3.875 & 1 (Brazil) & 45.650 & 1 (China) & 710.000 & 1 (China) & 2.900 & $1(E U)$ \\
\hline EU-27 & 12.000 & 3 & 1.300 & 3 & 24.050 & 2 & 271.500 & 2 & 2.900 & 1 \\
\hline Mexico & 3.500 & 7 & 6 & 24 & 1.305 & 10 & 19.800 & 7 & 180 & 7 \\
\hline Chile & 655 & 22 & 100 & 12 & 500 & 15 & NA & NA & 185 & 6 \\
\hline Indonesia & 1.700 & 12 & NA & & NA & NA & NA & NA & NA & NA \\
\hline Australia & 1.190 & 18 & 40 & 14 & 420 & 16 & NA & NA & 45 & 8 \\
\hline $\begin{array}{l}\text { New } \\
\text { Zealand }\end{array}$ & NA & NA & NA & NA & 48 & 29 & NA & NA & NA & NA \\
\hline Turkey & 2.250 & 8 & 425 & 6 & NA & NA & NA & NA & NA & NA \\
\hline Philippines & 1.310 & 16 & 3 & 28 & 1.600 & 8 & NA & NA & 1 & 23 \\
\hline $\begin{array}{l}\text { Smallest } \\
\text { listed }\end{array}$ & 2 & $\begin{array}{l}46 \\
\text { (Macedon } \\
\text { ia) }\end{array}$ & 1 & $\begin{array}{l}31 \\
\text { (Macedon } \\
\text { ia) }\end{array}$ & 2 & $\begin{array}{l}41 \\
\text { (Montenegrı }\end{array}$ & 5.385 & $\begin{array}{l}11 \\
\text { (Belarus) }\end{array}$ & 1 & $\begin{array}{l}25 \\
\text { (Bosnia } \\
\& \mathrm{H} . \text { ) }\end{array}$ \\
\hline
\end{tabular}

Source: https://www.indexmundi.com/agriculture/ (accessed 31-8-2018). NA: not available (presumably <

Smallest listed). Note: Indexmundi does not have information on eggs, layers or broiler numbers.

The table below is derived from Windhorst (2018; Tables 1, 2, 4 and 7) reporting on the egg industry in APEC countries.

Table 4. Data on people, economy and egg production and trade from Windhorst (2018).

\begin{tabular}{|c|c|c|c|c|c|c|c|c|c|c|}
\hline$\frac{8}{8}$ & 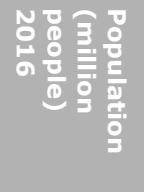 & 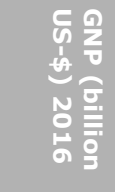 & 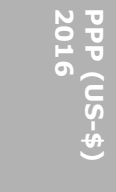 & 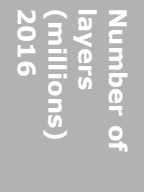 & 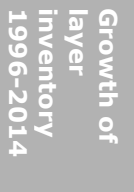 & 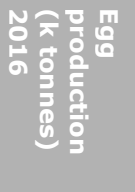 & 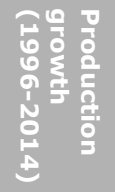 & 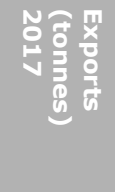 & 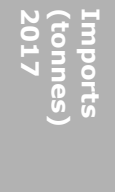 & 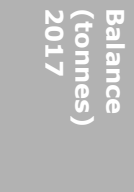 \\
\hline Mexico & 129 & 1.064 & 17.862 & 203 & $58 \%$ & 2720 & $120 \%$ & 0 & 22.226 & -22.226 \\
\hline Chile & 18 & 247 & 23.960 & 19 & $41 \%$ & 226 & $135 \%$ & NA & NA & NA \\
\hline Indonesia & 264 & 932 & 11.612 & 251 & $62 \%$ & 1428 & $127 \%$ & NA & NA & NA \\
\hline Australia & 24 & 1.205 & 46.790 & 16 & $14 \%$ & 237 & $74 \%$ & 170 & 0 & 170 \\
\hline New & 5 & 185 & 39.059 & 4 & $41 \%$ & 59 & $41 \%$ & 1.521 & 40 & 1.481 \\
\hline \multicolumn{11}{|l|}{ Zealand } \\
\hline Philippines & 105 & 305 & 7.806 & 90 & $107 \%$ & 450 & $118 \%$ & NA & NA & NA \\
\hline
\end{tabular}

Source: columns 1-3: FAO, World Bank and APEC data 2016. Last 3 columns: IEC Annual Review 2017. Middle columns: FAO (all data taken from Windhorst, 2018). GNP: Gross national product; PPP: Purchasing power parity; Turkey was not included in the report; NA: Not available.

\subsection{Animal welfare generally}

The table below shows the rankings on the API (Animal Protection Index, 2014), from A (best) to G (worst). The Animal Protection Index (API) ranks 50 countries around the world according to their commitment to protect animals and improve animal-welfare legislation. Note that both the API and the related VACI (Voiceless Animal Cruelty Index) index (see Annex 3 VACI, also for underlying scores related to national production and consumption levels based on FAO data) are disputable and inclusion in this report does not entail endorsement, merely an indication of possible differences between countries regarding animal welfare. Chile $(C L)$ has the highest overall API score in the Americas. Both the US and CA have an overall score D. Globally, the highest overall scores (A) are given to Austria 
(AT), UK, Switzerland (CH) and New Zealand (NZ). The lowest possible overall score (G) is given to Belarus, Iran and Azerbaijan. However, not all countries have been scored, e.g. in Europe Ireland and Portugal, the Baltic states, Norway and Finland have not been scored. This is also true for most countries in Africa and the Middle East.

The API was designed by a group of NGOs including World Animal Protection, RSPCA (Royal Society for the Protection of Animals in the UK), Eurogroup for Animals, IFAW (International Fund for Animal Welfare), HSI (Humane Society International) and CIWF (Compassion in World Farming), with involvement of the OIE (see https://api.worldanimalprotection.org/about, last accessed on November 4, 2011) (EC, 2017).

Table 5. Animal Protection Index (API) rankings for the different countries relevant to this report (MX: Mexico; CL: Chile; ID: Indonesia; AU: Australia; NZ: New Zealand; TR: Turkey; PH: Philippines) and several European countries for comparison (NL: The Netherlands; UK: United Kingdom; AT: Austria; $\mathrm{CH}$ : Switzerland).

\begin{tabular}{|c|c|c|c|c|c|c|c|c|c|c|c|}
\hline Topic & MX & CL* & ID & AU & NZ & TR & PH & NL & UK\# & AT\# & $\mathrm{CH} \#$ \\
\hline Overall & $\mathrm{D}$ & B & D & $\mathrm{C}$ & A & $\mathrm{E}$ & $\mathrm{C}$ & B & A & A & A \\
\hline \multicolumn{12}{|l|}{ Recognising animal protection } \\
\hline Formal recognition of animal sentience & $\mathrm{D}$ & $\mathrm{B}$ & C & C & $\mathrm{B}$ & C & B & A & A & A & A \\
\hline \multicolumn{11}{|l|}{ Animal Welfare } & A \\
\hline Laws against causing suffering & A & $\mathrm{D}$ & B & B & A & B & B & A & A & A & A \\
\hline \multicolumn{12}{|l|}{$\begin{array}{l}\text { animals used in farming (incl. } \\
\text { transport and slaughter) }\end{array}$} \\
\hline ... animals in captivity & C & $\mathrm{D}$ & D & C & A & D & D & $\mathrm{B}$ & $\mathrm{B}$ & B & B \\
\hline ... companion animals & $\mathrm{B}$ & $\mathrm{C}$ & D & $\mathrm{B}$ & A & C & $\mathrm{B}$ & A & A & A & $\mathrm{B}$ \\
\hline $\begin{array}{l}\ldots \text { animals used for draught and } \\
\text { recreation }\end{array}$ & C & B & $\mathrm{D}$ & $B$ & B & $D$ & $\mathrm{C}$ & B & B & A & B \\
\hline$\ldots$ animals used in scientific research & $\mathrm{D}$ & $\mathrm{C}$ & $E$ & A & A & C & B & A & A & A & A \\
\hline ... welfare of wild animals & $\mathrm{C}$ & $\mathrm{B}$ & $\mathrm{C}$ & C & $\mathrm{B}$ & $\mathrm{E}$ & $\mathrm{B}$ & $\mathrm{B}$ & $\mathrm{B}$ & B & $\mathrm{B}$ \\
\hline \multicolumn{12}{|l|}{ Governance } \\
\hline $\begin{array}{l}\text { Government accountability for animal } \\
\text { welfare }\end{array}$ & C & $\mathrm{B}$ & $\mathrm{D}$ & B & A & $\mathrm{F}$ & B & A & A & A & B \\
\hline \multicolumn{12}{|l|}{ Animal welfare standards } \\
\hline $\begin{array}{l}\text { Engagement with the World Organisation } \\
\text { for Animal Health (OIE) }\end{array}$ & $\mathrm{D}$ & $\mathrm{C}$ & $\mathrm{D}$ & D & $\mathrm{C}$ & $\mathrm{F}$ & C & $\mathrm{D}$ & $\mathrm{C}$ & C & C \\
\hline OIE animal welfare standards & $\mathrm{D}$ & $\mathrm{B}$ & $\mathrm{D}$ & B & A & $\mathrm{D}$ & C & A & B & A & B \\
\hline Reporting on progress & G & $\mathrm{D}$ & $\mathrm{E}$ & C & B & $E$ & C & $\mathrm{C}$ & C & A & A \\
\hline \multicolumn{12}{|l|}{ Providing humane education } \\
\hline Education on animal care and protection & D & $\mathrm{C}$ & D & $\mathrm{E}$ & D & D & D & $\mathrm{D}$ & $\mathrm{F}$ & B & C \\
\hline \multicolumn{12}{|l|}{ Promoting communication and awareness } \\
\hline Consultation with stakeholders & $\mathrm{C}$ & $\mathrm{C}$ & $\mathrm{C}$ & $B$ & $A$ & $E$ & A & $\mathrm{C}$ & A & A & A \\
\hline
\end{tabular}

Source: https://api.worldanimalprotection.org/\# (data from 2014). Scores from A (best) to G (worst). NA: not available. In bold: items on farming, i.e. most relevant for this report.

*Note: The highest-possible A grade for Chile regarding on-farm welfare legislation may be questioned when compared to the legislation existing in the EU countries (except for conditions at slaughter), i.e. Chilean legislation is not yet equivalent to the EU regarding transport and on-farm conditions (see Chapter 4 'Chile' below).

The EU has played a prominent role in raising awareness about animal welfare standards globally, including "Being a lighthouse in promoting pilot and voluntary industry initiatives, particularly in the laying hen and pig rearing sectors" (EC, 2017).

Overall, however progress (in third countries) has been slow and variable: It has been more clearly evident for animal welfare standards at slaughter, slightly less so for animal welfare standards at transport and much less so for animal-welfare standards at farm (EC, 2017). 
While there are some concerns, esp. for mature industries in structural crisis, generally EU animal welfare standards seem to have had a limited competitive impact for agricultural producers trading on the global market (EC, 2017).

Initially conceived as one of the EC's priorities in 2002, the promotion and mutual recognition of animal-welfare labels has subsequently been substantially played down and has become a residual component of the EU's international activities regarding animal welfare. At the same time, there was a growing tendency in the market towards promoting private labels and private certification schemes (EC, 2017). The main exception concerns labelling of organic products, where the EU has unilaterally recognised several third countries as having equivalent organic standards, including Australia, New Zealand and the US (EC, 2017). (Note that the US, for example, does not require outdoor access and allows the use of so-called verandas/porches, i.e. walled-in areas with a roof, hard floors and screening on one side and do not allow the birds outside, in organic poultry production; McDougal, 2018).

In some trade agreements with some countries like Chile and Mexico animal welfare may play a role in creating a market for organic products in partner countries, facilitating access to EU producers vis-àvis US competitors, and allowing Chilean exports of pasture-raised beef that could not be marketed in the EU as organic, but was to be generically sold as conventional (EC, 2017).

Between 2012 and 2015 the EU inspected 60 slaughterhouses in non-EU key exporting countries to the EU related to EU Regulation 1099/2009 on the protection of animals at the time of killing. The audits found the wide majority of bovine abattoirs to be fully compliant with EU standards, while some $15-25 \%$ of poultry slaughtering plants were found in need of additional investments. Pig abattoirs were only marginally inspected (EC, 2017).

Based on 90 stakeholder interviews, the EC found that non-EU operators were more likely than EU operators to report a higher productivity resulting from compliance with EU animal-welfare legislation, while both groups recognised that welfare compliance resulted in improved product quality (EC, 2017). If in the EU the current market of animal-welfare friendly products has a negligible size (with the exception of free-range eggs, over the study period 2004-2015), outside the EU this market is even less developed or does not exist at all (EC, 2017). However, according to an animal-welfare NGO representative not only in the EU and in the US the demand of animal-welfare friendly products is growing, but also in countries like Mexico and Brazil, especially for free-range eggs and pork (EC, 2017).

Demand for animal welfare in non-EU countries has mainly emerged in North America and Oceania, and EU animal-welfare international activities may have contributed to spread these practices also in Latin America (EC, 2017).

An issue of concern may be that the current world animal-welfare standards lack mutual trust on compliance (EC, 2017). Implementation of EU animal-welfare standards in non-EU countries, however, may result in a competitive advantage in the long run, as it seems to improve product quality and since the level of integration in those countries is usually higher compared to the EU (EC, 2017).

\subsection{References}

Bracke, M., 2009. Animal welfare in a global perspective - A survey of foreign agricultural services and case studies on poultry, aquaculture and wildlife. Report 240. Wageningen UR Livestock Research. Available at http://library.wur.nl/WebQuery/wurpubs/fulltext/49888. Accessed 14-10-2017.

EC, 2017. Study on the impact of animal welfare international activities. Brussels. Available at https://publications.europa.eu/en/publication-detail/-/publication/dc039353-ca9c-11e7-8e6901aa75ed71a1/language-en/format-PDF/source-49926262. Accessed 14-11-2018.

McDougal, T., 2018. Trump waters down US organic standards. Available at http://www.poultryworld.net/Meat/Articles/2018/3/Trump-waters-down-US-organic-standards261586E/?cmpid=NLC| worldpoultry|2018-0319|President_Trump_waters_down_US_organic_standards. Accessed 16-11-2018. Poultry World. March 19, 2018.

Poelsma, B., 2018. Varkensland Mexico is volop in beweging. July 15, 2018. De Boerderij. Available at https://www.boerderij.nl/Varkenshouderij/Achtergrond/2018/7/Varkensland-Mexico-is-volop-in- 
beweging-308761E/?cmpid=NLC\%7Cboerderij_varkenshouderij\%7C2018-07-

20\%7CVarkensland_Mexico_is_volop_in_beweging. Accessed 16-11-2018.

USDA Foreign Agricultural Service, 2018. [Query done on 8-11-2018 to retrieve production and trade data from 2016.] Available at https://apps.fas.usda.gov/psdonline/app/index.html\#/app/advQuery. Accessed 8-11-2018.

Van Horne, P., Hoste, R., Van Wagenberg, C., 2018. Production costs of the Mexican poultry and pig sector - Quick scan on the consequences for the EU poultry and pig sector after free trade with Mexico. Wageningen Economic Research, Wageningen. Available at http://edepot.wur.nl/443735. Accessed 14-11-2018.

Windhorst, H-W., 2018. Dynamics and patterns of the egg industry in APEC member countries. International Egg Commission. Available at http://1pfp2yazjqr27ku7g3h8zwwx-wpengine.netdnassl.com/wp-content/uploads/2018/07/Dynamics-and-patterns-of-the-egg-industry-in-APECmember-countries.pdf. Accessed 14-11-2018. 


\section{Mexico}

\subsection{Introduction}

To get an overview of the welfare status of pigs and poultry (layers and broilers) in Mexico, WLR collected information in November and December 2017 by local contacts and internet sources. For Mexico, but not for the other 6 third countries in this report, economic and performance data were also collected in cooperation with colleagues from Wageningen Economic Research (Van Horne et al., 2018).

\subsection{Animal welfare generally}

Mexico's overall API (Animal Protection Index) score level was low (D on a 5 point scale A to E; see Chapter 2 'Across countries' above), but its score for 'animals used in farming including transport and slaughter' was reasonably high (B). Mexico's VACI rank, which tries to take into account not just animal protection, but also farm-animal production and consumption, was in the median range, rank 26 out of 50 countries (see Annex 3, also for underlying scores related to national production and consumption levels based on FAO data).

All commercially-reared pigs and poultry are kept under intensive conditions and not limited by legislation except for some restrictions concerning transport and stunning at slaughter.

Several Latin American countries, including Mexico and Chile, participated in the Welfare Quality project (on monitoring of animal welfare) and the establishment of OIE Collaborating Centres in the region (EC, 2017).

Cockfighting is still [in 2003] a popular and mainstream sport in Southeast Asia as well as in countries like Spain, Mexico and the Philippines. Worldwide, cockfighting is a billion dollar a year industry (Hirsch, 2003).

\subsection{Layers}

\subsubsection{Production and trade}

The egg consumption is 371 per capita per year, so the 120 million Mexicans use 44.5 billion eggs each year (McDougal, 2017). The annual production is 2.7 - 2.9 million tonnes and 22-65.000 tonnes is imported, indicating a self-sufficiency of $98 \%$ (Hernandez and Parrish, 2017b; UNA, 2017). As such Mexico is one of the leading importers of eggs and egg products (EC, 2017; Windhorst, 2018).

\subsubsection{Welfare regulations}

There is no specific animal welfare legislation for layers on farm. There are only some general recommendations to provide enough space, feed and care to the animals, but these recommendations are not specified (SAGARPA, Federal law on animal health, 2007). Mexico, however, does have legislation on transport and slaughter (NN, 1998; NN, 2004).

\subsubsection{Practical conditions}

Layers are typically kept in cages with a space allowance of about $345-400 \mathrm{~cm}^{2} /$ hen (Battery cage example in Mexico, 2018). Beaks are trimmed in the first week. In 2016 a good practices manual was revised for layers. With regard to animal welfare, specific guidelines on beak trimming (first week, 4.2 $\mathrm{mm}$ shortened, hot blade), density (450 $\mathrm{cm}^{2} /$ layer) and 16 hours light of 10-20 lux are being advised (SAGARPA, 2016a). In practice forced moulting is common: hens are left without food and water for 
3-4 days or sold to other farms for forced moulting and start of another cycle of egg laying. This happens 2-3 times depending on the egg price (Miguel-Pacheco, Pers. comm.). At the slaughterhouse the birds are stunned electrically using a water bath.

\subsubsection{Trends}

Although Mexican layer farming is highly intensive, the discussion about welfare has started. In 2016 multiple Mexican restaurant chains announced a commitment to serve only cage free eggs (The Poultry Site, 2016). However, the national egg producers union is in favour of enriched cages, and until recently they were not accepting cage free production as the new standard (Miguel-Pacheco, Pers. comm.).

\subsection{Broilers}

\subsubsection{Production and trade}

The chicken consumption is $32 \mathrm{~kg}$ per capita ( 3.8 million tonnes) and for more than $80 \%$ covered by national production (3.3 million tonnes; UNA, 2017) with most of the imports coming from the USA (Hernandez and Parrish, 2017b).

\subsubsection{Welfare regulations}

There is no specific animal welfare legislation for on farm broilers. There are only some general recommendations about providing enough space, feed and care to animals, but just in general terms (Federal law on animal health, SAGARPA, 2007). Mexico, however, does have legislation on transport and slaughter (NN, 1998; NN, 2004).

\subsubsection{Practical conditions}

No quantified information about stocking density was found. However the good practices manual (SAGARPA, 2016b) mentions a maximum density of 15-19 broilers per $\mathrm{m}^{2}$ or $36-39 \mathrm{~kg}$ per $\mathrm{m}^{2}$. The light intensity should be at least 10 lux. Birds are caught manually with often 3 birds per hand and by one leg (Miguel-Pacheco, 2018). At the slaughterhouse the birds are stunned electrically using a water bath.

\subsubsection{Trends}

No formal measures to improve broiler welfare by market parties are known. Broilers are mainly produced for the internal market. The societal pressure now seen in egg and pork production could also affect broiler farming conditions. Conditions of poultry (and other farmed species, i.e. pigs, ruminants and horses) at slaughter may be an issue of concern, as was documented by an activist photographer, Aitor Garmendia, in Mexico between 2015 and 2017 (Tras los Muros, 2017).

\section{$3.5 \quad$ Pigs}

\subsubsection{Production and trade}

Mexican pig production is not self-sufficient, but growing rapidly. The 1.2 million sows produce around 1.4 million tonnes of pork, and Mexico imports another 1 million tonnes, mainly from the USA. But with NAFTA under pressure, this import is at stake and Mexico hopes to be self-sufficient within 5 years (Hernandez and Parrish, 2017a; Garcia, 2017).

It's the third largest importer of pig meat. The country has $\sim 16.7$ million pigs. Pork consumption is $18.6 \mathrm{~kg} / \mathrm{capita}$, and growing. Export amounts to 0.1 million tonnes. About $77 \%$ of pigs are kept on family farms ( $20 \mathrm{ha}$ ). The new trade agreement with the EU almost completely liberalised the pig 
meat trade between Mexico and the EU. An issue of concern is the use of ractopamine, which is still used in Mexico as a growth promotor (Poelsma, 2018).

Ractopamine and zilpateral, which also a beta-agonist, are still allowed, but little is known about their use (Miguel-Pacheco, Pers. comm.).

\subsubsection{Welfare regulations}

There is no specific animal welfare legislation for on-farm pigs. There are only some general recommendations about providing enough space, feed and care to animals, but just in general terms (Federal law on animal health, SAGARPA, 2007). However, Mexico has legislation on transport and slaughter. It is recommended to provide pigs with spray cooling on hot days to prevent heat stress during transport. The floor should offer grip to prevent slipping. Transport should not exceed 20 hours with maximum periods of 8 hours. Following a transport duration of at most 8 hours, there should be a stop in the shade of 1 hour. The space allowance for $100 \mathrm{~kg}$ pigs should be at least $0.45 \mathrm{~m}^{2}$ per pig during transport. At the slaughterhouse pigs should undergo a veterinary inspection. However, law enforcement is not very strong (Miguel-Pacheco, Pers. comm.).

The Ministry of Agriculture (SAGARPA, 2004) developed guidelines for good husbandry practices for pig farms in cooperation with the farmers' organisation (Porcimex).

\subsubsection{Practical conditions}

Pigs are kept in intensive husbandry conditions with sows individually housed in gestation stalls $(0.65$ $\mathrm{m} \times 2.20 \mathrm{~m}$ ) and farrowing crates. Tails are docked and males are castrated without anaesthesia or analgesia. Most pigs are kept on fully slatted floors and for new weaner houses $0.4 \mathrm{~m}^{2} / \mathrm{pig}$ and for growing-finishing pigs $1.0 \mathrm{~m}^{2}$ is advised as a good farming practice. However, most commerciallyfarmed pigs will be housed under more intensive conditions. Most of the pig houses have open side walls to stimulate ventilation and prevent heat stress in the mixed tropical/desert climate.

\subsubsection{Trends}

Although Mexican farming is highly intensive, the discussion about welfare has started. In 2016 a special issue of the magazine Porcicultores focused on animal welfare (see Porcicultores, 2016). In the same year a Mexican restaurant chain announced a commitment to serve only crate-free pork (The Pig Site, 2017). Conditions of pigs (and other farmed species, i.e. poultry, ruminants and horses) at slaughter may be an issue of concern, as was documented by an activist photographer, Aitor Garmendia, in Mexico between 2015 and 2017 (Tras los Muros, 2017).

\subsection{References}

Battery cage example in Mexico, 2018. Available at http://www.milenio.com/cultura/Gallinas_MILIMA20140831_0016_1.jpg. Accessed 8-2-2018.

EC, 2017. Study on the impact of animal welfare international activities. Brussels. Available at https://publications.europa.eu/en/publication-detail/-/publication/dc039353-ca9c-11e7-8e6901aa75ed71a1/language-en/format-PDF/source-49926262. Accessed 14-11-2018.

Garcia, D.A., 2017. Top Mexican pork firm plans \$550 million expansion, amid U.S. trade tension. March 24, 2017. Reuters. Available at https://www.reuters.com/article/us-usa-mexico-tradepork/top-mexican-pork-firm-plans-550-million-expansion-amid-u-s-trade-tensionidUSKBN16V02W. Accessed 20-11-2018.

Hernandez, G., Parrish, M.R., 2017a. Mexico - Livestock and Products Semi-annual - Mexico's Livestock Sector Remains Healthy. USDA. Available at https://gain.fas.usda.gov/Recent\%20GAIN\%20Publications/Livestock\%20and\%20Products\%20Se mi-annual_Mexico\%20City_Mexico_3-12-2017.pdf. Accessed 22-12-2017.

Hernandez, G., Parrish, M.R., 2017b. Mexico - Poultry and Products Annual - Poultry and Eggs are Pillars of Production. USDA. Available at https://gain.fas.usda.gov/Recent\%20GAIN\%20Publications/Poultry\%20and\%20Products\%20Annu al_Mexico\%20City_Mexico_9-20-2017.pdf. Accessed 22-12-2017. 
Hirsch, V. 2003. Detailed Discussions of Legal Protections of the Domestic Chicken in the United States and Europe. Available at https://www.animallaw.info/article/detailed-discussion-legal-protectionsdomestic-chicken-united-states-and-europe. Accessed 6-1-2019.

NN, 1998. NORMA Oficial Mexicana NOM-051-ZOO-1995, Trato humanitario en la movilización de animales. (Legislation concerning transport.) Available at http://dof.gob.mx/nota_detalle.php?codigo=4870842\&fecha=23/03/1998. Accessed 8-2-2018

NN, 2004. NORMA Oficial Mexicana NOM-194-SSA1-2004, Productos y servicios. Especificaciones sanitarias en los establecimientos dedicados al sacrificio y faenado de animales para abasto, almacenamiento, transporte y expendio. Especificaciones sanitarias de productos. (Legislation concerning stunning and slaughter.) Available at http://www.salud.gob.mx/unidades/cdi/nom/194ssa104.html. Accessed 8-2-2018.

Porcimex (Pig Farmers Organisation), 2017. http://www.porcimex.org/bienestar.htm. Accessed 22-122017.

Porcicultores, 2016. Special issue. Available at https://issuu.com/concienciaveterinaria/docs/porcicultores_109_baja. Accessed 8-2-2018.

McDougal, T., 2017. AI, fipronil and welfare issues dominate IEC (International Egg Commission) reviews. Poultry World. Sept 13, 2017. Available at https://www.poultryworld.net/Eggs/Articles/2017/9/AI-Fipronil-and-welfare-issues-dominate-IECreviews-183186E/. Accessed 16-11-2018.

SAGARPA, 2004. Manual de Buenas Prácticas de Producción en Granjas Porcícolas. Available at http://www.sagarpa.mx/ganaderia/Publicaciones/Lists/Manuales\%20de\%20Buenas\%20Prcticas/At tachments/6/manual_porcino.pdf. Accessed 22-11-2018.

SAGARPA, 2007. Ley federal de sanidad animal (Federal law on animal health). Available at https://www.gob.mx/cms/uploads/attachment/file/118761/LFSA.pdf. Accessed 22-11-2018.

SAGARPA, 2016a. Manual de buenas practices pecuarias en la producción de huevo para plato. Available at http://www.una.org.mx/images/yootheme/Documentos/Manuales/MANUALBPPHUEVOPARAPLATO. pdf. Accessed 8-2-2018.

SAGARPA, 2016b. Manual de buenas practices pecuarias en la producción de pollo en engorda. Available at http://www.una.org.mx/images/yootheme/Documentos/Manuales/MANUALBPPPOLLODEENGORDA .pdf. Accessed 8-2-2018.

The Pig Site, 2016. First Mexican Restaurant Chain Commits to Crate-Free Pork. August 11, 2016. The Pig Site. Available at http://www.thepigsite.com/swinenews/42217/first-mexican-restaurantchain-commits-to-crate-free-pork/. Accessed 8-2-2017.

The Poultry Site, 2016. Another Restaurant Chain Switches to Cage-Free Eggs in Mexico. The Poultry Site. Nov. 29, 2016. Available at http://www.thepoultrysite.com/poultrynews/37892/anotherrestaurant-chain-switches-to-cagefree-eggs-in-mexico/. Accessed 22-12-2017.

Tras los Muros, 2017. Matadero. Lo que la industria cárnica esconde. // Documental. (Slaughtershouse. What the meat industry hides. // Documentary). Available at https://www.youtube.com/watch?v=gY0vCambWRA\&feature=youtu.be\&has_verified $=1$. Accessed 19-12-2018.

UNA (Unión Nacional de Avicultores), 2017. Indicadores Económicos - Compendio de Indicadores Económicos del Sector Avícola 2017. Unión Nacional de Avicultores. Available at http://www.una.org.mx/index.php/component/content/article/2-uncategorised/19-indicadoreseconomicos. Accessed 30-1-2018.

USDA Foreign Agricultural Service, 2018. [Query done on 8-11-2018 to retrieve production and trade data from 2016.] Available at https://apps.fas.usda.gov/psdonline/app/index.html\#/app/advQuery. Accessed 8-11-2018.

Van Horne, P., Hoste, R., Van Wagenberg, C., 2018. Production costs of the Mexican poultry and pig sector - Quick scan on the consequences for the EU poultry and pig sector after free trade with Mexico. Wageningen Economic Research, Wageningen. Available at http://edepot.wur.nl/443735. Accessed 14-11-2018.

WAP (World Animal Protection), 2014. Mexico. Available at https://api.worldanimalprotection.org/country/mexico. Accessed 21-11-2018.

Windhorst, H-W., 2018. Dynamics and patterns of the egg industry in APEC member countries. International Egg Commission. Available at http://1pfp2yazjqr27ku7g3h8zwwx-wpengine.netdna- 
ssl.com/wp-content/uploads/2018/07/Dynamics-and-patterns-of-the-egg-industry-in-APECmember-countries.pdf. Accessed 14-11-2018. 


\section{$4 \quad$ Chile}

\subsection{Introduction}

To get an overview of the welfare status of layers, broilers and pigs in Chile, WLR collected information especially in February and March 2018 by local contacts and internet sources.

\subsection{Production and trade generally}

Chile has a population of 18 million people and a surface area of $756.096 \mathrm{~km}^{2}$ (Van Dooren, 2014). Chile is an exporter of poultry meat, and exports significant amounts of pig meat to the EU, but is not subjected to the implementation of the same animal welfare standards for pigs at farm (EC, 2017). In total, there are about 120 operational slaughterhouses (for the various farmed species) in Chile, of which less than $20 \%$ are certified for exports to the EU (EC, 2017).

\subsection{Animal welfare generally}

Chile has the highest API-welfare score in the America's (see Chapter 2 'Across countries' above): B on a on a 5 point scale ( $A$ to $E$ ). It received a score $A$ (best possible) for 'animals used in farming including transport and slaughter', though it may be noted that this is a score similar to the score given to most EU countries, including the Netherlands, and as shown below, it may be disputed if welfare levels for main farm animals, esp. pigs and poultry, as indeed comparable (but the welfare of extensively-reared beef cattle may be better in Chile compared to the generally more intensive beef production in the EU). Chile's VACI rank, however, which tries to take into account not just animal protection, but also farm-animal production and consumption, was also reasonably high, rank 16 out of 50 countries (see Annex 3, also for underlying scores related to national production and consumption levels based on FAO data).

Chilean producers focus on the competitive advantage of animal welfare. Animal welfare standards are defined as standards for the protection of animals in compliance with the OIE standards (Eurogroup for animals, 2013). The animal-welfare legislation in Chile is called '20.380 Protección de Animales'(11/09/2009 promulgation). This regulation identifies products for which killing and transport need to take into account animal welfare. Also, the law establishes the rules necessary to provide an adequate care to animals with the aim to avoid unnecessary distress. Finally, the law identifies needs in terms of capacity building for a department specialised in animal welfare. (Eurogroup for animals, 2013). Other welfare regulations in Chile are Decreto N 28/2013 'Regulation on the protection of animals that provide meat, fur, feathers, and other products at the moment of slaughter at industrialized establishments', Decreto N 29/2013 'Regulation on the protection of animals during breeding, commercialization, and at other places where animals are maintained', and Decreto $\mathrm{N}$ 30/2013 'Regulation on the protection of animals during transport' (Gallo and Tadich, 2018). Law 19162 (the Meat Act) regulates the meat industry, including making provisions for livestock rearing, slaughter and keeping conditions of livestock and livestock products (WAP, 2014).

Some producers go beyond the legal minimum requirements (e.g. in their company guidelines). Chile is moving towards achieving the status of equivalent at slaughter with EU animal-welfare standards (except for certification of the skills of personnel; EC, 2017).

The EU-Chile Association Agreement 2003 was the first bilateral trade agreement to mention animal welfare. Since then Chile has developed rules for the welfare of animals, mainly during transport and slaughter. Chile and Uruguay together established a regional (South America) OIE Collaborating Centre on Animal Welfare with the support of the OIE (Cabanne, 2013; EC, 2017). The animal welfare centre at the Universidad Austral de Chile organised the regional ISAE meeting for Latin America in December 2018. With over 200 attendants the 4-day meeting (http://www.bienestaranimal.cl/1216-2; 
www.congresobaisae2018.com) indicated increasing interest in animal welfare in the region, esp. on large and small ruminant welfare (e.g. the welfare of sheep transported along the coast of Chile). Relatively few presentations concerned pigs and poultry as it is more difficult to do research in collaboration with the large integrated companies involved in pig and poultry production (Anon., Pers. comm.).

Chile was involved in the Welfare Quality project (monitoring of farm-animal welfare), and in the EU training program (BTSF, Better Training for Safer Food), esp. on transport and slaughter (EC, 2017). In Chile there is little evidence of specific consumer demand for animal-welfare products. However, an increase in the consumption of organic and environmentally-friendly products (esp. free-range eggs) has been recorded in recent years (EC, 2017). A survey on consumer preferences in Latin America (incl. Chile and Mexico) conducted by WAP (World Animal Protection) indicated that 78\% of consumers would buy products with higher animal-welfare standards only if they were available at equal price (i.e. no premium price is recognised); $42 \%$ declared to be willing to pay more for certified welfarefriendly animal products, but 54\% did not trust the related labelling (EC, 2017).

Chile has a substantial salmon industry ( $~ 582.000$ tonnes in 2017), that may raise concerns. It has been affected by elevated mortality rates (e.g. ISA virus in 2008; algae bloom in 2016), and a very high use of antibiotics (1500 times as much as the Norwegian salmon industry), leading to degraded biodiversity and an adverse effect on local fisheries (Van Staalduinen, 2018).

\subsection{Layers}

\subsubsection{Production and trade}

In Chapter 2 'Across countries' above we reported that in 2016 Chile had 19 million layers, producing 226.000 tonnes of eggs (Windhorst, 2018; 3.6 billion, ODEPA, 2016; Ricke and Gast, 2017). The Chilean egg sector consists of about 131 companies/integrations but not all of them cover the full value chain (OECD, 2017). As opposed to the meat sub-sector, farm size within the poultry layer subsector is diverse (Hamilton-West et al., 2012). Around 60 farms accounted for $90 \%$ of the production (Ricke and Gast, 2017).

\subsubsection{Welfare regulations}

The legislation is very general (applying across species and generally following OIE standards, e.g. farmers must provide comfort, but it doesn't specify stocking densities, etc.). The government asked the livestock sectors to prepare their own guidelines, validated by an expert group. So far these have been prepared for dairy cattle and laying hens. The guidelines for layers (SAG, 2018) are a step in the direction of being more specific, but they still lack the required detail. For example, maximum stocking densities for layers have not been specified in the guidelines either. Farmers prefer to follow the recommendations provided by the companies/integrations. Another example concerns perches, which have been specified for cage-free housing only (as they are not present in the conventional cages, nor are other provisions like a nest, enrichment, and a dust bath). However, also for perches the minimum $\mathrm{cm} /$ bird have not been specified, and observations in practice on free-range farms have indicated that the provision of perches was insufficient (not enough perches for all birds to perch; Zapata, Pers. comm.).

\subsubsection{Practical conditions}

Most layers are kept in conventional battery cages ( $95 \%)$. About $\sim 5 \%$ is cage free (including free range and, for example, aviaries; Zapata, Pers. comm.). Farmers in Chile commonly practice beak trimming, using a hot iron blade ( $90 \%)$. One producer uses IR (infrared beak trimming) and paracetamol for 7 days after beak trimming. Something like one free-range farm is not practicing beak treatment (Zapata, Pers. comm.).

For transport generally (layers, broilers and pigs) OIE guidelines are followed in Chile (Zapata, Pers. comm.). This is also true for slaughter. 


\subsubsection{Trends}

International trade has played a role in improving animal welfare. In 2015 an initiative was started to produce free-range eggs on a fair trade basis promoting the welfare of hens (low stocking density on organic pasture) and respect for the environment (Linden, 2015). In 2016, a Chilean laying-hen farmer received the Good Egg Award, indicating commitment to improve animal welfare standards (Clements, 2016).

\subsection{Broilers}

\subsubsection{Production and trade}

As indicated above (in Chapter 2 'Across countries') the mean broiler production in Chile amounts to 622.000 MT CWE, with an import of 130.000 MT CWE and an export of 106.000 MT. The domestic consumption is 646.000 MT CWE (USDA, 2018; data from 2016).

Chile produces 285 million broilers/year, a number that has been growing steadily over the past decade (e.g. from 224 million in 2010; ODEPA, 2017a).

Poultry is the highest consumed meat (Gomez, 2016) with 37.5 kg/capita in 2013 (De los Angeles Gutiérrez, 2014).

The Chilean poultry meat sector is highly integrated, controlling the entire process from parent stock farms to slaughter. Only four companies/integrations operate in the broiler segment (OED, 2017). A small number of broilers is kept in small farms as backyard production.

\subsubsection{Welfare regulations}

Chile does not have specific welfare requirements for broilers. For transport and slaughter OIE-like standards apply.

\subsubsection{Practical conditions}

The livestock production systems in Chile are very similar to other countries with intensive production (as in the EU and the US, esp. the US; Zapata, Pers. comm.).

No information (i.e. precise data) was found about stocking densities, broken bones or footpad dermatitis of broilers in Chile. Big producers have their own guidelines, and they seem to be similar to the EU (suggesting stocking densities like $40 \mathrm{~kg} / \mathrm{m}^{2}$; not $50 \mathrm{~kg} / \mathrm{m}^{2}$ ).

Broilers generally have wood shavings (mixed with earth) as bedding on an earth floor (similar to the US).

For transport generally OIE guidelines are followed in Chile (Zapata, Pers. comm.). This is also true for slaughter.

EU animal welfare audits in four Chilean poultry slaughterhouses in 2013 showed recurrent deficiencies related to animal welfare, but Chile is moving towards achieving the status of equivalent at slaughter with EU animal-welfare standards, but for poultry differences remain (EC, 2017).

\subsubsection{Trends}

No information was found on this subject.

\subsection{Pigs}

\subsubsection{Production and trade}

As indicated above (in Chapter 2 'Across countries') the mean pig production in Chile amounts to 508.000 MT CWE; 76.000 MT CWE imports and 173.000 MT CWE exports. The domestic consumption is 411.000 MT CWE (USDA, 2018; data from 2016); about 16 kg/capita, (Martínez Herráez, 2016). 
Chile produces (a fairly steady number of) 4.9 million pigs/year (ODEPA, 2017b). Chile is the $6^{\text {th }}$ biggest pig meat exporter worldwide. Its pork industry has grown substantially in the past decades (Martínez Herráez, 2016). Chile is the leading foreign supplier of pig meat to the EU, and has replaced the US (though EU imports of pig meat from both these countries have reduced and remain negligible; EC, 2017).

Compared to e.g. Mexico, Chile has a very intensive and professional pig production sector, which is rather inaccessible, due to its high and increasing level of integration (Anon., Pers. Comm.; Van Dooren, 2014; EC, 2017). 220.000 sows are owned by 40 companies; 5 companies are in the lead. Agrosuper has 120.000 sows and many large farms with several thousands of sows and their finishers. Piglet production is on average 27-28 slaughter pigs/sow/year. The sector is paying relatively low wages and is putting little restrictions on using antibiotics (but is using less than e.g. Mexico and Brazil). The growth promotor ractopamine is not allowed in Chile (Van Dooren, 2014).

A notable incident occurred in 2012 when residents of the town of Freirina successfully protested against the unpleasant smell of a 500.000 large pig production site and slaughterhouse owned by Agrosuper. In response, the government closed the plant, leading to the death of pigs due to starvation and lack of water. Eventually the site was closed permanently (Van Dooren, 2014).

\subsubsection{Welfare regulations}

To our knowledge, Chile does not have specific welfare requirements for pigs on-farm. For transport and slaughter, however, the Chilean regulations are in accordance with the OIE standards, and for slaughter they are on a level playing field with the EU (EC, 2017).

\subsubsection{Practical conditions}

The livestock production systems are generally very similar to other countries with intensive production (Zapata, Pers. comm.). The main type of floor is fully slatted or partial slatted concrete floors. Weaners are kept on flat decks. Very few pigs are kept on straw.

Most pregnant sows are kept in individual crates/stalls (not tethered) (EC, 2017; Zapata, Pers. comm.). The recommendation is $2 \mathrm{~m} \times 60 \mathrm{~cm}$. (Note that this is similar to the standard US gestation crate measuring $6.6 \mathrm{ft} \times 2.0 \mathrm{ft}$; (https://en.wikipedia.org/wiki/Gestation_crate), which is small compared to the EU requirement of $2.25 \mathrm{~m}^{2}$ for an adult sow in group housing.) Similar dimensions apply to the farrowing crates. There is no requirement for providing enrichment. (Virtually) all pigs are tail docked. Surgical castration is done without anaesthesia or analgesia (see also Grandin, 2014). Immunological castration (IMPROVAC $($ ) is increasingly implemented and one company has explored using environmental enrichment. Castration and tail docking are common practice (EC, 2017). Chile has, mainly, a production system in multiple sites, though some producers still have mono-site or farrow-to-finish systems. About 27 piglets are weaned per sow per year. The ADG (average daily weight gain) during fattening is (a respectable) 893 grams/pig/day. Chile has a high health status, supported by natural barriers (Pacific ocean and Andes mountains; Cubillos, 2012). Chile is free from the major diseases and in the process of eradicating PRRS (Porcine Reproductive and Respiratory Syndrome; Martínez Herráez, 2016).

Most of the herds are concentrated in a small number of large operations, and numerous small establishments exist alongside. Many pig farmers are relatively aged and have a low level of education (OECD, 2017).

Slaughterhouses for pigs (and poultry, cattle and sheep) have made welfare adjustments such as improved holding pens and stunning. This has resulted in conditions similar to those applying in the EU (except for poultry, where differences with OIE standards remain; EC, 2017).

\subsubsection{Trends}

The World Animal Protection campaign in Chile calls for group housing (with room for sows to move, and enrichment to alleviate boredom), the end of mutilations on piglets (including the cutting of teeth, ears and tails without anaesthesia), and more space for growing pigs kept in sheds (to avoid fighting and the spread of disease; WAP, 2017). 
Cabanne, C., 2013. The EU-Chile association agreement: A booster for animal welfare. BIORES, 7. Available at https://www.ictsd.org/bridges-news/biores/news/the-eu-chile-association-agreementa-booster-for-animal-welfare. Accessed 22-11-2018.

Clements, M., 2016. Global appetite for poultry welfare rewarded. WattAgNet, July 20, 2016. Available at https://www.wattagnet.com/articles/27554-global-appetite-for-poultry-welfare-rewarded. Accessed 23-11-2018.

Cubillos, R., 2012. Description of the Chilean pig sector. 14 May 2012. Available at \#ch3 https://www.pig333.com/articles/description-of-the-chilean-pig-sector_5742/. Pig333.com. Accessed 24-11-2018.

De los Angeles Gutiérrez, M., 2014. Poultry meat consumption in Chile on the rise. Poultry World, Sept. 19, 2014. Available at https://www.poultryworld.net/Meat/Articles/2014/9/Poultry-meatconsumption-in-Chile-on-the-rise-1603134W/. Accessed 21-11-2018.

EC, 2017. Study on the impact of animal welfare international activities. Brussels. Available at https://publications.europa.eu/en/publication-detail/-/publication/dc039353-ca9c-11e7-8e6901aa75ed71a1/language-en/format-PDF/source-49926262. Accessed 14-11-2018.

Eurogroup for Animals, 2013. The EU-Chile Free Trade Agreement-a Boost for Animal Welfare. Available at http://trade.ec.europa.eu/doclib/docs/2013/december/tradoc_151962.pdf. Accessed 21-11-2018.

Gallo, C.S, Tadich, T.G., 2018. Perspective from Latin America. In: Advances in Agricultural Animal Welfare: 188-218. Available at https://www-sciencedirectcom.ezproxy.library.wur.nl/science/article/pii/B9780081012154000110. Accessed 21-11-2018.

Gomez, B., 2016. Developing World Antitrust - Developing countries pose unique challenges to antitrust law - The chain reaction of the poultry cartel in Chile. Jan. 18, 2016. Available at https://developingworldantitrust.com/2016/01/18/the-chain-reaction-of-the-poultry-cartel-inchile/. Accessed 21-11-2018.

Grandin, T., 2014. Livestock Handling and Transport, 4th Edition: Theories and Applications. CABI, Wallingford, UK.

Hamilton-West, C., Rojas, H., Pinto, J., Orozco, J., Hervé-Claude, L.P., Urcelay, S., 2012. Characterization of backyard poultry production systems and disease risk in the central zone of Chile. Research in Veterinary Science 93 (1): 121-124. Available at http://dx.doi.org/https://doi.org/10.1016/j.rvsc.2011.06.015. Accessed 21-11-2018.

Linden, J., 2015: Chile puts fair trade poultry to the test. WattAgNet, Nov 24, 2015. Available at https://www.wattagnet.com/articles/25072-chile-puts-fair-trade-poultry-to-the-test. Accessed 2111-2018.

Martínez Herráez, N., 2016. Chilean Pork Industry has grown $800 \%$ in last 30 years. The Pig Site, June 29, 2016. Available at http://www.thepigsite.com/swinenews/41974/chilean-pork-industry-hasgrown-800-in-last-30-years/. Accessed 21-11-2018.

ODEPA (Ministerio de Agricultura), 2016. [Number of eggs produced]. Available at http://www.odepa.gob.cl/wp-content/uploads/2017/01/Producción-de-huevos.xls. Accessed 2211-2018.

ODEPA (Ministerio de Agricultura), 2017a. [Numbers of broilers slaughtered]. Available at http://www.odepa.gob.cl/informe-con-detalle-regional-y-mensual-pecuario . Accessed 22-112018.

ODEPA (Ministerio de Agricultura), 2017b. [Number of pigs slaughtered]. Available at http://www.odepa.gob.cl/informe-con-detalle-regional-y-mensual-pecuario. Accessed 22-11-2018.

OECD (Organisation for Economic Co-operation and Development, Trade and Agriculture Directorate, Committee for Agriculture), 2017. Producer incentives in livestock disease management. Chile case study. TAD/CA/APM/WP(2017)2/FINAL. Available at http://www.oecd.org/officialdocuments/publicdisplaydocumentpdf/?cote=TAD/CA/APM/WP(2017)2 /FINAL\&docLanguage=En. Accessed 21-11-2018

Ricke, S.C., Gast, R.K. (eds), 2017. Producing Safe Eggs: Microbial Ecology of Salmonella. Academic press. Available at https://books.google. $\mathrm{nl} /$ books? id=xBUoCgAAQBAJ\&pg=PA96\&lpg=PA96\&dq=chile+layer+eggs\&so urce $=$ bl\&ots $=$ GhCidJgqf\&sig=sKc2RbRIwm_NMm3JIarI8hs95rk\&hl=nI\&sa=X\&ved=0ahUKEwj_waO- 
g6jZAhXSjqQKHY6bAg04ChDoAQhSMAU\#v=onepage\&q=chile\%20layer\%20eggs\&f=false .

Accessed 21-11-2018.

SAG, 2018. Guía de buenas prácticas sobre bienestar animal en los diferentes sistemas de producción de huevos. Servicio Agrícola y Ganadero. Available at http://www.sag.cl/sites/default/files/bienestar_animal.pdf. Accessed 21-11-2018.

The Poultry Site, 2016. Chile Increases Broiler Meat Production by Over 5 Per Cent. April 13, 2016. Available at http://www.thepoultrysite.com/poultrynews/36867/chile-increases-broiler-meatproduction-by-over-5-per-cent/. Accessed 21-11-2018.

USDA Foreign Agricultural Service, 2018. [Query done on 8-11-2018 to retrieve production and trade data from 2016.] Available at https://apps.fas.usda.gov/psdonline/app/index.html\#/app/advQuery. Accessed 8-11-2018.

Van Dooren, K., 2014. Chile's pork engine is slowing down. Pig Progress, Dec. 19, 2014. Available at https://www.pigprogress.net/World-of-Pigs1/World-of-Pigs/Country-

focus1/?cmpid=ILC|Tool|C3_contentmarketing|in-article|in-article|countryfocus. Accessed 22-112018.

Van Staalduinen, R., 2018. Sectoroverzicht: de Chileense zalmindustrie. Report. Available at https://www.agroberichtenbuitenland.nl/documenten/verslagen/2018/09/29/de-chileensezalmindustrie. Accessed 23-11-2018.

WAP (World Animal Protection), 2014. Chile. Available at https://api.worldanimalprotection.org/country/chile. Accessed 21-11-2018.

WAP (World Animal Protection), 2017. Millions of pigs in China set to have better lives, while support grows in Brazil and Chile. Available at https://www.worldanimalprotection.org/news/millions-pigschina-set-have-better-lives-while-support-grows-brazil-and-chile Accessed 21-11-2018. 


\section{$5 \quad$ Indonesia}

\section{$5.1 \quad$ Introductie}

This chapter is largely based on information from one of the co-authors of this report, Rick van Emous, as collected in his report in preparation (Van Emous, 2018). Several other anonymous contacts provided supplementary information, and internet sources were consulted.

\subsection{Production and trade generally}

Indonesia is the largest economy in South East Asia and the $4^{\text {th }}$ most populated country. It has $\sim 266$ million inhabitants, estimated to increase to 320 million in 2015 (www.worldometers.info), of which $87 \%$ is Muslim (Van Emous, 2018).

Indonesia imports poultry genetics, but it does not import or export chicken meat. Indonesia banned day-old chick imports (but not SPF (Specified Pathogen Free) and hatching eggs) from the USA in 2015, following high-pathogen AI outbreaks (Wright and Darmawan, 2017). Avian Influenza (AI) is endemic in Indonesia.

Food security and food safety are top priorities in Indonesia (Jabbar, 2015). Animal welfare is much less relevant. About 5\% of people are living below the poverty line, which amounts to $\sim 20$ million people. The poultry industry involves many small scale farmers ( $70 \%$ is contract farming), and it employs more than $80 \%$ of the workforce in the livestock industry, hence it is an important economic driver for rural areas in Indonesia (Premier, 2014).

Indonesia may (potentially) produce chicken meat and eggs at a price comparable to Thailand (currently a main exporting country; Wahyono and Utami, 2018).

\subsection{Animal welfare generally}

Indonesia's overall API (Animal Protection Index) score level was rather low ( $D$ on a 5 point scale; see Chapter 2 'Across countries' above; score $C$ for 'animals used in farming including transport and slaughter'). Its VACI rank, however, which tries to take into account not just animal protection, but also farm-animal production and consumption, was relatively high, rank 9 out of 50 countries (see Annex 3, also for underlying scores related to national production and consumption levels based on FAO data).

Maltreatment of animals is banned (Indonesian Penal Code/Criminal Code, Chapter XIV - Crimes against decency, Article 302). Animal housing, care, transport and slaughter is to be regulated (Law No. 6 of 1967 Concerning Basic Provisions on Husbandry and Animal Health, Article 22 - Animal Welfare). This seems to have been done only in general terms in Law No. 18 of 2009 Concerning Husbandry and Animal Health, Article 66-67 - Animal Welfare. It recognises, for example, that all vertebrates and some invertebrates have the capacity to feel pain. Thus, from a legal perspective, Indonesia cares for its animals. In Law No. 18/2009, the capacity to feel pain is deemed a prerequisite obligating ethical treatment of animals. Article 66 of the Law recognises the 5 freedoms in husbandry and animal health, and Article 67 indicates that the Indonesian public seems to have a responsibility in enforcing animal-welfare laws. Public participation is crucial because currently law enforcement concerning animal welfare in Indonesia is still poor and has yet to achieve its goals. However, another constraint is the society's low awareness and lack of concern towards animal welfare (DFAS, Pers. comm. 2016). Government Regulation number 95 of 2012 concerning veterinary public health and animal welfare specifies animal welfare in accordance with what was stated above.

The anti-cruelty provisions of the Criminal Code apply to farm and laboratory animals, but there is no legislation specifically regulating animal testing (WAP, 2014). Testing cosmetics on animals is legal in 
Indonesia (Wikipedia, 2018). Livestock transportation and slaughter are to be conducted so that animals are free from fear, pressure, and torture.

New regulations (such as Regulation No. 26/Permentan/PK.230/5/2016 on live broilers) seem to have been issued with the interests of the industry in mind (DBS, 2017). In addition, there is concern about compliance regarding chicken slaughter (fraudulence; chicken carcasses entering the market from illegal poultry slaughterhouses with doubtful hygiene and halal qualifications; Apriantini and Adhi, 2017). Indonesia is implementing very strict halal legislation. This may, perhaps, also adversely affect the welfare of farm animals (esp. poultry and beef) at the time of slaughter (Whitehead, 2018). Existing provisions on farming are not detailed. There is a lack of knowledge and education about humane treatment of animals. There is a lack of recognition of animal sentience by society at large, and significant financial barriers. The government has established a sub-directorate within the ministry of Agriculture with responsibility for animal welfare (WAP, 2014).

The University of Queensland (Australia) developed poultry (layers, broilers and ducks) welfare guidelines for ASEAN (the voluntary Association of South East Asian Nations, incl. Indonesia and the Philippines), covering cruelty, welfare, biosecurity, product quality and the environment (Phillips, 2016). The ASEAN Good Animal Husbandry Practices (GAHP) for Layers and Broilers Food Safety Module serve as a standard for countries with existing GAHP in Asia (such as Indonesia and the Philippines) to start a harmonisation process (Premier, 2014; Jabbar, 2015). Policies and regulations are mainly implemented by the Directorate General Livestock and Animal Health Service and supported by the National Centre Research and Development for Animal Husbandry and the National Veterinary Research Institute. A National GAHP (Good Animal Husbandry Practices) program has started, supported by ministerial regulations (Premier, 2014).

The ASEAN GAHP for layers and broilers on food safety is also dealing with basic animal welfare requirements such as to avoid suffering and providing adequate food, water and space, and e.g. to transport animals "at the coldest time of the day in order to avoid heat stress" (Premier, R, No date). There is also an ASEAN GAHP specifically about animal welfare and environmental sustainability for layers and broilers, building (again) on OIE standards (Australian Aid, No date).

Mutilations such as de-beaking, de-toeing, tail-docking, tooth pulling, castration, and dehorning of livestock without anaesthetic are legal, as is confinement in gestation crates and battery cages (WAP, 2014).

Sheep may be kept in narrow, wooden crates (kept a bit like veal calves; Van Emous, Pers. observation.).

Organised dog fighting is illegal (Articles 170, 241, 302 and 406 Criminal Code). Nevertheless dog fighting events remain popular in the country. Another concern is the welfare of captive wild and zoo animals (WAP, 2014), indicating a general lack of concern in society for animal welfare generally (Bale, 2017). Animal rights activism or opposition to animal agriculture is rare (Wikipedia, 2018). Indonesia's animal welfare organizations include the Bali Street Dog Foundation, the Jakarta Animal Aid Network (JAAN), the Bali Animal Welfare Association (Wikipedia, 2018) and the Indonesia Society for Animal Welfare (ISAW, No date).

There are about 500.000 stray dogs on Bali. The government advises people to kill stray dogs rather than place them in a shelter. The most common method of killing strays is strychnine poisoning, which is painful (Cochrane, 2015). More than 100.000 dogs are eaten in Indonesia at present (NOS, 2018). Other animals sold in the "pet meat" trade include cats, rabbits, bats, rats, pigs, and snakes. Footage of pet meat markets shows dogs being clubbed to death or burned alive with blow torches (Akbar, 2015). Local animal rights groups and JAAN have campaigned for the last few years to end the dog meat trade in Indonesia (JAAN, No date; cited from Wikipedia, 2018). Indonesia is preparing a regulation to ban the trade of meat derived from pets and exotic animals, aiming to promote animal welfare and rein in rabies. The decision was cheered by the NGOs, but it is not known when it would take effect (The Straight Times, 2018).

\subsection{Layers}

\subsubsection{Production and trade}

In Chapter 2 'Across countries' above we reported that in 2016 Indonesia had 251 million layers, producing 1.4 million tonnes of eggs (Windhorst, 2018). 


\subsubsection{Welfare regulations}

We did not find specific (i.e. quantified) welfare requirements for laying hens comparable to the requirements in the EU.

\subsubsection{Practical conditions}

The majority of layers is kept in traditional battery cages. Beak trimming is common, as is forced moulting (but depending on the egg price; Van Emous, Pers. comm., via local contact).

The stocking density is probably $\sim 600 \mathrm{~cm}^{2}$ (for caged layers). A common light schedule is $16 \mathrm{hL}$ or so (traditional, much light; Van Emous, Pers. comm.).

\subsubsection{Trends}

The market (e.g. retailer and food service like Sodexo) appears to be (interested in) moving towards cage-free eggs (The Poultry Site, 2018; HSI, 2018; McDougal, 2018).

\section{$5.5 \quad$ Broilers}

\subsubsection{Production and trade}

As indicated above (in Chapter 2 'Across countries') the mean broiler production in Indonesia amounts to 1.6 million MT CWE, with no import or export of any significance (USDA, 2018; data from 2016; Wright and Darmawan, 2017; Van Emous, 2018). The domestic consumption is 1.6 million MT CWE (USDA, 2018; data from 2016).

Indonesia is a major producer of chicken meat, with the second-largest chicken flock in the world (behind China) at 5.1 billion chickens (broilers and layers) in 2016 (Anon., 2018). The total broiler production accounted for $66 \%$ of the national meat supply in 2016 (Wahyono and Utami, 2018). Poultry production increased significantly since the early 1980 s ( $\sim 10 \%$ per year in recent years). Estimates of the commercial poultry sector in 2015 indicate a total of 3.5 billion broilers, 200 million layers and 25 million breeders (Wright and Darmawan, 2017).

Most broilers are produced in Java $(\sim 72 \%)$ esp. West Java $(33.3 \%)$, which is more densely populated. Poultry meat consumption has increased in recent years, but it is still relatively low (approx. $7 \mathrm{~kg}$ per capita in 2011; USAID, 2013; approx. $15 \mathrm{~kg}$ in 2017; Wright and Darmawan, 2017), but expected to increase with 53\% by 2023 (Rabobank 2014, cited from Van Emous, 2018).

Poultry meat accounts for about $87 \%$ of total Indonesian meat consumption, due to its greater affordability and dietary restrictions on pig meat for religious reasons (Santoso, 2016).

The commercial broiler-breeding sector in Indonesia relies on the supply of grandparent stock imported from the US and Europe (FeedTechIndonesia, 2014).

Contract-type (also called 'plasma') farms produce some $70 \%$ of the broilers on a large number of farms ( $>20.000)$. In this system, the contractor provides day-old chicks, feed and medication, and intermediate agents provide the link between contractor and farmer (Van Emous, 2018; Pers. comm.). Grown broilers are collected from farms for delivery to company-owned slaughterhouses (processing $10-15 \%$ of the broilers) or are collected by agents and enter the wet market system. About 10 large companies/integrations control $70 \%$ of broiler production. They are, however, investing heavily in building up their own farms. The main companies are Charoen Pokphand and Japfa Comfeed, which account for 40 and $26 \%$ of the day-old-chick production respectively (Van Emous, 2018).

\subsubsection{Welfare regulations}

We did not find specific (i.e. quantified) welfare requirements for broilers comparable to the requirements in the EU. 


\subsubsection{Practical conditions}

Broilers are mainly kept in so-called open houses, but also in closed and semi-closed houses (FoodTechIndonesia, 2014).

Open houses account for 95\% of farms (FoodTechIndonesia, 2014). These are open sided buildings with bamboo slats; they mostly have an open water system, manual feeding, some larger houses have recirculation fans for cooling; they are, heated by coal fires or small gas heaters; waste falls to the ground; they may have a pond with live fish to process wet waste; 6-100.000 birds/farm in 2-5 buildings; 3-20.000 birds/building; $8-10$ birds $/ \mathrm{m}^{2}$; raising broilers to a body weight of $1.4-1.7 \mathrm{~kg} / \mathrm{bird}$; 5-10.000 birds/employee; the FCR (Food Conversion Ratio) is $1.55-1.6$ and mortality levels are $5-8 \%$ (FoodTechIndonesia, 2014).

Small-scale broiler farmers (with open houses and $2.000-10.000$ birds/farmer) account for $>90 \%$ of Indonesia's broiler farms (Brienen, 2018).

Closed houses: $2 \%$ of farms; steel construction, plastic sides which can be rolled up in the event of an electricity blackout; insulated; fully automated (feed, water, climate: cooling and heating); some have a plastic sheet to collect waste; typically 20-200.000 birds per farm in 1-2 buildings (but may also have 400.000 birds on a farm); 20-100.000 birds/building; $15-20$ birds $/ \mathrm{m}^{2} ; 1.8-2.0 \mathrm{~kg} / \mathrm{bird} ; 30-$ 50.000 birds/employee; FCR: 1.4-1.5; mortality <3\% (FoodTechIndonesia, 2014).

Semi-closed houses: $3 \%$ of farms, wood \& steel construction with plastic sides which can be opened; insulated; automated, closed water system, some have automatic feeding, fan cooled, heated by electric lamps; waste: manually cleaned after a cycle; 20-100.000 birds/farm in 1-2 buildings; 2050.000 birds/building; $12-14$ birds/m²; $1.8-2.0 \mathrm{~kg} / \mathrm{bird} ; 25-40.000$ birds/employee; FCR: 1.4-1.5; mortality 2-4\% (FoodTechIndonesia, 2014).

Open houses have a high roof and natural ventilation, whereas closed houses have a low ceiling and mechanical tunnel ventilation, automatic feeding and watering, and (semi) closed side walls (with plastic curtains) and closed floors with litter (Van Emous, 2018; see figures 2 and 3).

Most birds are farmed in small open houses containing 3.000-20.000 birds, which have high mortality rates (up to $8 \%$; even 20\%; Brockotter, 2018) due to disease (low biosecurity; poor quality drinking water) and high temperatures (heat stress; Larive, 2017).
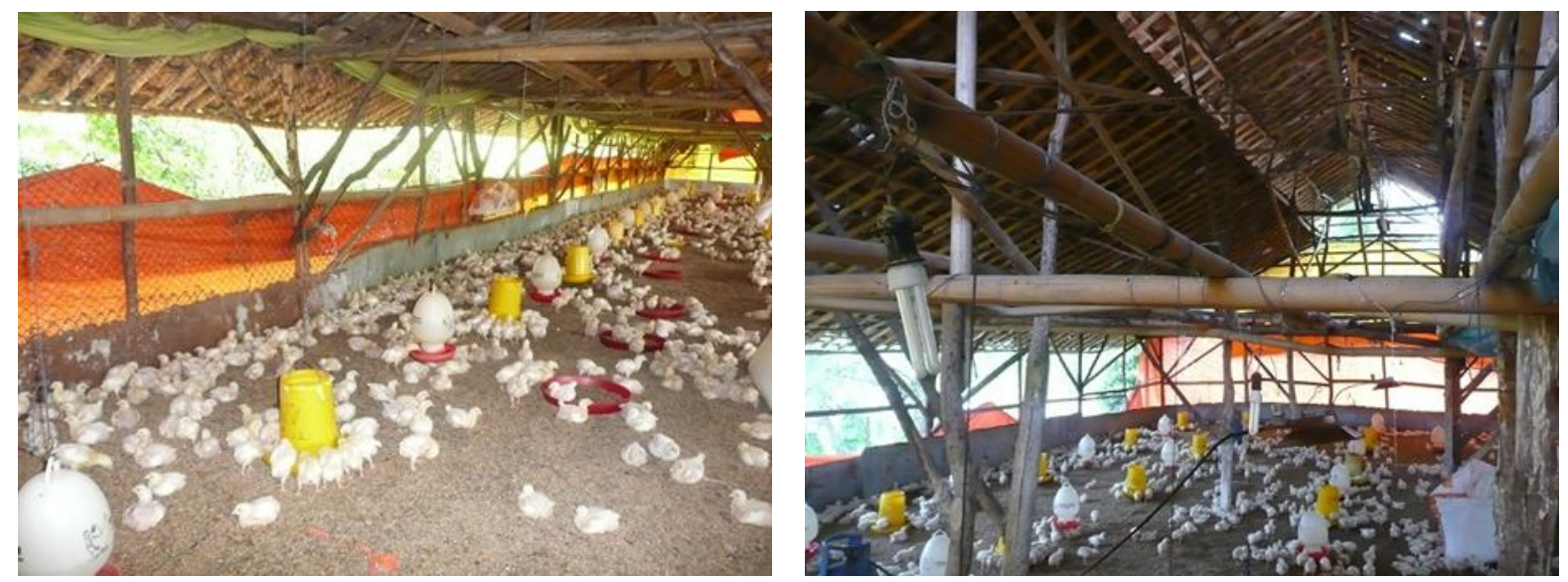

Figure 2. Traditional open broiler house with a high roof, natural ventilation, open side walls and manual feeding (From Van Emous, 2018). 

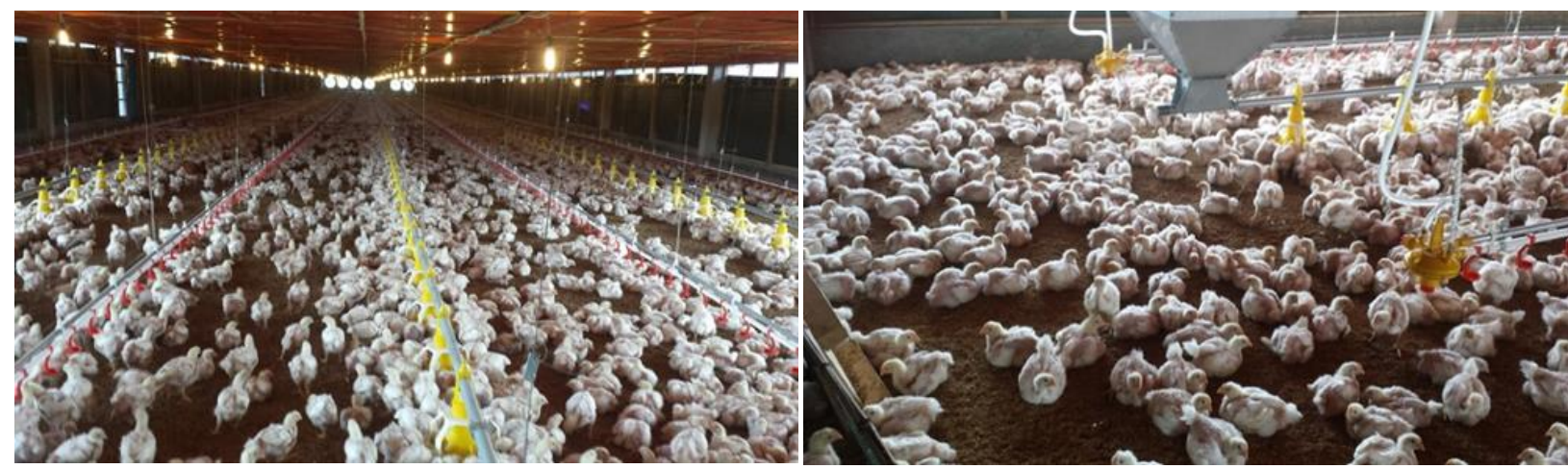

Figure 3. Closed broiler house with 2 floors with a low ceiling, tunnel ventilation, (semi) closed side walls (with plastic curtains) and automatic feeding (From Van Emous, 2018).

Using open houses for broilers is a low-cost (and low-output) solution. The last decade a gradual shift is observed from intensive, open-housed systems to semi or totally-closed houses with automated ventilation (Van Emous, 2018).

For bedding often a relatively thick layer of rice hulls is used. Few or no food pad lesions are seen (Van Emous, Pers. obs.). Thermoregulation is a welfare concern, esp. in open houses. This is true both at a young age (when the night-time temperature may be around $20{ }^{\circ} \mathrm{C}$ and poor quality gas heaters are used to raise the environmental temperature for the chicks), and esp. also at the second part of the production phase during hot and humid conditions (Van Emous, Pers. comm.).

Sick and weak broilers (e.g. lame birds) are not always euthanized. They may be sold locally, and this presents both a disease and welfare risk (Van Emous, Pers. comm.).

An inventory (carried out by Van Emous et al.) in 2017 at 15 commercial broiler farms showed, on average, a daily dosage of antibiotics per animal year (DD/Y) of 133 . (In the Netherlands it is 10.5 $D D / Y$ ). Surprisingly, the average daily dosage for semi-closed houses was higher (160 vs. 116) than for open broiler houses, despite improved biosecurity and ventilation (less heat stress). The higher use of antibiotics in the semi-closed systems was probably caused by the routine use of antibiotics (out of convenience and/or as an 'insurance') in the daily management of the farms (Van Emous, 2018). Antibiotic Growth Promotors (AGP) have been banned as of January 2018 in Indonesia (as indicated by a 2017 Rabobank report, cited in Koeleman, 2017). Antibiotics use for therapeutic purposes is still allowed for up to 7 days under veterinary supervision (Koeleman, 2017), and there may be concern if and when this regulation may be enforced (see also above).

The majority of chicken slaughter takes place in backyard facilities (76\%; FoodTechIndonesia, 2014). Only $24 \%$ are slaughtered in abattoirs, and only 34 abattoirs hold a veterinary certificate which allows them to sell to supermarkets, fast food restaurants, and hotels (Brienen et al., 2014). Backyard slaughtering (with poor hygiene and safety) is officially illegal, but the law is hardly enforced. About $95 \%$ of all chickens are sold fresh; only $5 \%$ is processed. The remaining part is slaughtered in semiautomated slaughtering facilities with intermediate capacity and a few automated slaughtering lines with high capacity. The transition towards industrial slaughter is a slow process (Van Emous, 2018). During catching, which can stretch over a period of more than a week, several small trucks enter the farm facility. Besides movement and stress for the birds (from catching, being carried upside-down, weighing and transport itself), the overall cleanliness of the vehicles and crates are far from ideal (Brockotter, 2018; Van Emous, Pers. comm.). Figure 4 shows examples of poultry transport and electrical stunning in Indonesia. 

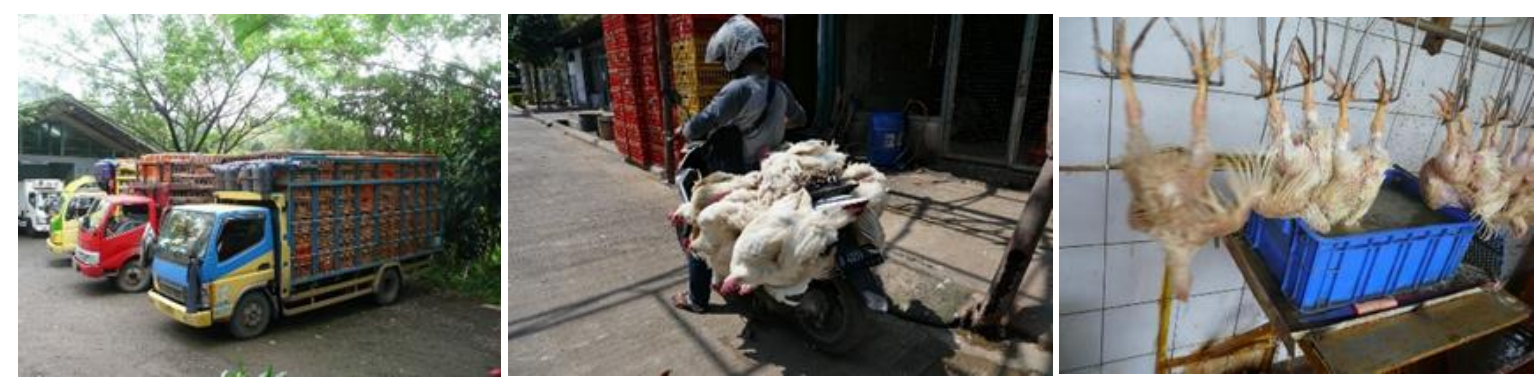

Figure 4. Examples of poultry transport and electrical stunning in a local slaughterhouse in Indonesia.

Most transport is over relatively short distances (most poultry farms are near cities) and occurs usually at night as there are many traffic jams in the daytime and it is cooler at night. Small trucks usually carry 1.5-2.000 birds in crates. When transported by scooter and in small trucks, birds may be made wet for cooling. The quality of the roads and infrastructure is often poor (Van Emous, Pers. comm.).

Slaughter is also an issue of concern, esp. also related to the quality of the water bath stunning (probably resulting in a relatively high percentage of ineffective stuns; see Figure 4 which, it should be noted, is not representative of conditions in commercial slaughterhouses licenced for export to the EU) and hygiene (Reimert, Pers. comm.).

Other welfare issues related to stunning include the requirement of Halal slaughter, and inadequate shackle sizes being used for smaller sized birds (FoodTechIndonesia, 2014).

The welfare of birds transported on the back of scooters is likely to be low, and the crates on the trucks could, for example, be spaced more apart for better cooling to reduce heat stress (Reimert, Pers. comm.).

Backyard production accounts for a substantial part of the poultry meat consumption (about 20\%; Directorate General of Livestock Services, 2001). It typically involves rearing the so-called Ayam Kampung chicken to a body weight of $1-1.5 \mathrm{~kg}$ in 4-5 months (Engku Azahan, 1994). The chickens scavenge for feed which includes kitchen waste, insects, worms, grasses and vegetables. The scavenging local chicken could play a role in pest control in rice and corn production (Nataamijaya et al., 1996). Local chickens are preferred by most consumers and its meat is more expensive than the broiler meat. However, the productivity of the local chicken is low. Productivity of Kampung chicken, one of the main local breeds, appears to be extremely low, presumably due to poor nutrition and disease. The mortality rate up to the age of 6 weeks is very high (50-56\%). Kampung chicken can lay between 45 and 56 eggs per year (Mansjoer, 1989). Chicks remain with their mothers for a period of 2-3 months, after which period the hen will start the next egg-laying period. Kampung chicken perform well in intensive systems where the average number of eggs laid is 3 times higher, but when reared intensively for meat production they were inefficient and had higher feed conversion ratios than commercial breeds (Mansjoer, 1989). The majority of local farmers in the villages cannot afford to maintain imported layers and broilers mainly due to a low education level and the high investment required.

\subsubsection{Trends}

The Netherlands and Indonesia work together to strengthen the Indonesian poultry sector (Larive, 2017). A slow but irreversible transformation is taking place in the Indonesian poultry meat production sector, from traditional to more modern housing systems. Wageningen Economic Research did a case study into the economics of closed versus open broiler houses in West Java. Better production performance leads to $11 \%$ lower production costs per $\mathrm{kg}$ final live weight. Part of the collaboration also relates to the Modern Broiler Learning Centre. The test centre used $15 \mathrm{birds} / \mathrm{m}^{2}$, but good production will inevitably lead to increased stocking densities (Brockotter, 2018).

Another innovation that may take place in Indonesia is the use of the BroMaxx cage system for broilers (made by Jansen Poultry Equipment, JPE, No date). This is a broiler housing system that promises improved climate control, hygiene and animal health, and therefore better growth and a more uniform broiler flock with premium meat quality. The system is designed for high bird density (up to $50 \mathrm{~kg} / \mathrm{m}^{2}$ ) and smart harvesting methods result in significant labour savings. Antibiotic use is expected to diminish in this system, leading to improved food safety and human health. The BroMaxx 
system is a modern kind of battery cage for housing multiple (3) layers/levels of broilers kept in colony-group cages (of 60 birds per cage) on a flexible (nylon) floor (Van Emous, 2018). Following the implementation of this system in the Philippines, a training centre (the MBLC centre in West Java) will be equipped with this system, thus facilitating the transition from traditional open houses to modern broiler farming with increased production efficiency (Van Emous, 2018).

When given a choice broilers lie on the plastic wire floor more often than on litter. In the Netherlands broilers can only sit on litter, which is mixed with manure. As of an early age ( $\sim 17$ days of age) (sham) dustbathing may be observed in broilers, e.g. near the feeder on the wire floor. There is no problem with foot pad lesions when broilers are kept in cages. In the BroMaxx system the nylon floor segments can be pulled out to drop the broilers on the conveyer belt and transport them out of the broiler house, resulting in less handling and fewer broken bones. Above all, however, the BroMaxx system has improved air quality due to high-quality ventilation (where air is directed to the animals) in a well-insulated building where manure is removed out of the bird house using the conveyor belt under the wire floors (Van Emous, Pers. comm.). By contrast, the EU legislation could be improved regarding cooling. The sum of the temperature and the relative humidity $(\mathrm{RH})$ is a good measure of heat stress ( $>100$ implies heat stress; 95 is comfortable). This is very important when it is hot $\left(>30^{\circ}\right.$ C) (Van Emous, Pers. comm.). Note: Annex II of Council Directive 2007/43/EC specifies that, when the outside temperature measured in the shade exceeds $30^{\circ} \mathrm{C}$, the inside temperature does not exceed this outside temperature by more than $3^{\circ} \mathrm{C}(\mathrm{EC}, 2007)$.

\subsection{Pigs}

Indonesia is a predominantly Muslim country ( $~ 87 \%$ of the population is Muslim). It was, therefore, considered unlikely to develop a strong pig sector producing pig meat for the (inter-)national/EU market. Hence, we limited our exploration of pig welfare conditions in Indonesia to a broad internet search.

\subsubsection{Production and trade}

The pork production in 2013 was 743.000 tonnes (up 78\% compared to 2001) (FAO data, cited from Jabbar, 2015). More than 50\% of national pork production is in East Indonesia (Budaarsa, 2017). Indonesia has gained market shares in exporting live swine (EC, 2017). It exported live pigs worth USD 30.25 million to Singapore in the first half of 2016. In Central Java there are around 0.8 million pigs reared intensively. If guided and provided with good processing facilities, pig farmers in this region could meet export requirements (UkrAgroConsult, 2017). Indonesia has a substantial nonMuslim minority ( 25 million) and many Western tourists who can eat pork (Lumb, 2013). However, feed prices are high and this may limit the capacity to export pork (Van Emous, Pers. comm.).

\subsubsection{Welfare regulations}

We did not find specific (i.e. quantified) welfare requirements for pigs comparable to the requirements in the EU.

\subsubsection{Practical conditions}

One article (Lumb, 2014) describes 3 farm visits.

One 400-sow farrow-to-finish facility had buildings with very high roofs to allow air circulation. Most pens had solid floors and were washed down frequently, with the manure seemingly ending up in a nearby river. The farm had 27 staff, a high number by Western standards; nothing was mechanised. The farrowing crates were elevated about $1 \mathrm{~m}$. above ground level and had metal slats. The gestating sows were housed in stalls. Old hessian bags on the floor prevented new born piglets' legs getting between the metal slats. Piglets had their incisors cut, their tails docked (using a thin string being tied around the tail rather than being cut off) and male piglets were castrated. Weaning was late by European standards ( 5 weeks) and sows produced $\sim 16$ piglets/sow/year. Sows were served twice naturally using boars. The farm manager was Muslim who did not eat pork but had no problem working with pigs. Some of the weaner pens had fully slatted floors made of steel (Lubm, 2014). 
Pigs were slaughtered at around $110 \mathrm{~kg}$ using a remarkable handling procedure. Each pig was fixed in a sausage - shaped wire cage, closed at both ends. A pole was then slid through the cage to carry the pig by 2 employees. However, there was no struggling or squealing.

Pigs were then weighed individually, loaded on to a large truck, and hosed down with water (for cooling). The pigs were slaughtered in Jakarta after a 10-hour journey, which must have a negative impact on the killing out percentage (cited from Lumb, 2014).

A second farm fed the pigs in the evenings when it was cooler. The farm had 345 small crates which housed finishing pigs, which were fed individually. The same concept was also popular in East Yorkshire (UK) - but back in the 1970s. All the pigs were ear notched (Lumb, 2014).

A third pig farmer was using AI (artificial insemination) and produced 21 pigs/sow/year. The farmer also stated that ractopamine was allowed in Indonesia, along with beta-agonists (Lumb, 2014). Backyard pig farming is a common practice in eastern Indonesia. The mean number of pigs per herd is 5. Many farmers ( $83 \%)$ own at least one sow. Most pigs $(74 \%)$ are housed in a kandang (small bamboo pen) and $25 \%$ are tethered. The majority of farmers have little or no knowledge about biosecurity. Most farmers (65\%) have never seen a veterinarian or animal health worker visit their village. Backyard slaughter is common practice (55\%; Leslie et al., 2015). Backyard production varies from (very) small pens and tethering to free-roaming (e.g. on Papua; Siagiaan, 2014).

\subsubsection{Trends}

There are various ceremonies with roasted pig. The ceremony called bakar batu in Papua also uses pigs: the head of tribe shoots the pig with bow and arrow from close range, while the pig is restrained (Budaarsa, 2017).

Budaarsa (2017) concludes that "Based on the potential of natural and human resources, associated with the program of Nawa Cita of the current government, East Indonesia is very likely to become the centre of pork livestock. The production is not only to satisfy the food need in the country but also for export target. Investors of pork livestock (need to) obtain legal protection, that they can feel comfortable and safe in doing their business".

\subsection{References}

Akbar, J., 2015. Knocked out with a club and blowtorched ALIVE: How 'hundreds of thousands' of dogs and cats are being cruelly slaughtered for meat in Indonesian markets. Sept. 23, 2015. Available at https://www.dailymail.co.uk/news/article-3243481/Knocked-club-blowtorched-ALIVE-hundredsthousands-dogs-cats-cruelly-slaughtered-meat-Indonesian-markets.html. Accessed 3-12-2018.

Apriantini, A., Adhi, A. K., 2017. Regulatory Framework for Poultry Slaughterhouses: Case Study in Debotabek Area, Indonesia. Jurnal Ilmu Produksi dan Teknologi Hasil Peternakan 5. Available at \#45 http://journal.ipb.ac.id/index.php/ipthp/article/view/19622. Accessed 24-11-2018.

Anon. 2018. Number of chickens worldwide in 2016, by country (in million animals). Available at https://www.statista.com/statistics/263961/top-countries-worldwide-by-chicken-stock-2007/. Accessed 24-11-2018.

Australian Aid, No date. ASEAN Good Animal Husbandry Practices (GAHP) - Animal Welfare and Environmental Sustainability Module for Layers, Broilers and Ducks. Australian Aid. Available at http://aadcp2.org/asean-good-animal-husbandry-practices-gahp-animal-welfare-environmentalsustainability-module-layers-broilers-ducks/. Accessed 25-11-2018.

Bale, R., 2017. Cheap Thrills, Poor Conditions Plague Indonesia's Zoos. National Geographic, Feb. 3, 2017. Available at \#59 https://news.nationalgeographic.com/2017/02/wildlife-watch-indonesiazoos-animal-welfare/. Accessed 25-11-2018.

Brienen, M., Cavenagh, B., van Vliet, W., Copier, M., 2014. Meeting the challenge of Indonesia's growing demand for poultry. WattAgNet, June 20, 2014. Available at https://www.wattagnet.com/articles/19161-meeting-the-challenge-of-indonesia-s-growingdemand-for-poultry. Accessed 24-11-2018.

Brienen, M., 2018. FoodTechIndonesia offers training to poultry farm managers in South Sulawesi. DFAS. May 30, 2018. Available at https://www.agroberichtenbuitenland.nl/actueel/nieuws/2018/05/30/foodtechindonesia-offerstraining-to-poultry-farm-managers-in-south-sulawesi. Accessed 26-11-2018. 
Brockotter, F., 2018. Ventilation in the poultry house makes a world of difference. Aug .19, 2017. Poultry World. Available at https://www.poultryworld.net/Meat/Articles/2017/8/Ventilation-in-thepoultry-house-makes-a-world-of-difference-173187E/. Accessed 26-11-2018.

Budaarsa, K., 2017. East Indonesia as the Center of Pig Production. International Journal of Agriculture Innovations and Research 6, 2319-1473. Available at https://simdos.unud.ac.id/uploads/file_penelitian_1_dir/368902bd60b5c694fed44d4b3d8b2ae4.pd f. Accessed 3-12-2018.

Cochrane, J. 2015. 'If you see a stray dog, just kill it': Bali's canine debate heats up after 10-year-old girl bitten on the beach. The New York Times, March 5, 2015. Available at http://www.nationalpost.com/m/search/blog.html?b=news.nationalpost.com/2015/03/05/balistray-dog-problem/\&q=stray dog kill it. Accessed 3-12-2018.

DBS, 2017. New Broiler Regulations: Limited Impact. DBS Bank, Jan. 9, 2017. Available at https://www.dbs.com/aics/templatedata/article/generic/data/en/GR/012017/170109_insights_ne w_broiler_regulations_limited_impact.xml. Accessed 24-11-2018.

DFAS, Pers. comm. 2016. See also 'Regulations concerning animal welfare in Indonesia'. ISAW (Indonesian Society for Animal Welfare). Available at https://www.isaw.or.id/samplepage/regulations-concerning-animal-welfare-in-indonesia/ . Accessed 24-11-2018.

Directorate General of Livestock Services. 2001. Statistical Book on Livestock. Direktorat Jenderal Bina Produksi Peternakan, Ministry of Agriculture, Jakarta. Cited from

http://agtr.ilri.cgiar.org/index.php?option=com_content\&task=view\&id=91\&Itemid=108. Accessed 30-11-2018.

EC, 2007. Council Directive 2007/43/EC of 28 June 2007 laying down minimum rules for the protection of chickens kept for meat production. Available at https://eurlex.europa.eu/LexUriServ/LexUriServ.do?uri=OJ:L:2007:182:0019:0028:EN:PDF. Accessed 17-42019.

EC, 2017. Study on the impact of animal welfare international activities. Brussels. Available at https://publications.europa.eu/en/publication-detail/-/publication/dc039353-ca9c-11e7-8e6901aa75ed71a1/language-en/format-PDF/source-49926262. Accessed 14-11-2018.

Engku Azahan, E.A., 1994. The red and black-red native chickens of Malaysia [Ayam kampung Malaysia jenis merah dan hitam-merah]. Archived 3 September 2014 at the Wayback Machine. Malaysian Agricultural Research and Development Institute (MARDI) Research journal 22 (1): 7378. Cited from https://en.wikipedia.org/wiki/Ayam_Kampong. Accessed 30-8-2018.

FoodTechIndonesia, 2014. Adding value to the Indonesian poultry sector. Larive international. March $13,2014$.

HSI, 2018. Asian food industry leaders put animal welfare on their agenda. Humane Society International. April 5, 2018. Available at http://www.hsi.org/news/press_releases/2018/04/indonesia-roundtable-farm-welfare040518.html. Accessed 25-11-2018.

ISAW, No date. Indonesia Society for Animal Welfare. Available at https://www.isaw.or.id/?lang=en. Accessed 3-12-2018.

JAAN, No date. Dogs are not food. Jakarta Animal Aid Network. Available at www.jakartaanimalaid.com/domesticcampaigns/dogs-are-not-food/. Accessed 3-12-2018. Cited from Wikipedia (2018).

Jabbar, M.A., 2015. ASEAN Strategic Plan of Action for the Livestock Sub-Sector 2016-20. Available at https://www.researchgate.net/publication/296831882_ASEAN_Strategic_Plan_of_Action_for_the_ Livestock_Sub-Sector_2016-20. Accessed 25-11-2018.

JPE, No date. The BroMaxx broiler housing system (BroMaxx vleeskuiken huisvestingssysteem). Available at https://www.jpe.org/producten/vleeskuikensector/bromaxx/bromaxx-vleeskuikenhuisvestingssysteem/. Accessed 30-11-2018.

Koeleman, E., 2017. Outlook - Indonesian protein market. AllAboutFeed.net. Nov. 8, 2017. Available at https://www.allaboutfeed.net/Compound-Feed/Articles/2017/11/Outlook---Indonesian-proteinmarket-208804E/. Accessed 26-11-2018.

Larive, 2017. Dutch experts train Indonesian poultry farmers. Larive. April 7, 2017. Available at \#20 https://www.larive.com/indonesian-poultry/ . Accessed 26-11-2018.

Leslie, E.E., Geong, M., Abdurrahman, M., Ward, M. P., Toribio, J.A., 2015. A description of smallholder pig production systems in eastern Indonesia. Preventive Veterinary Medicine 118: 319-27. Available at \# 7 https://www.ncbi.nlm.nih.gov/pubmed/25572130. Accessed 3-12-2018. 
Lumb, S., 2014. Pig Farming, Javanese-style. The Pig Site, Oct. 31, 2014. Available at http://www.thepigsite.com/swinenews/39122/survey-of-indonesian-pig-farmers-reveals-need-fortraining/. Accessed 3-12-2018.

Mansjoer, S.S., 1989. Genetics characters and performance of Indonesian native chickens. Research Report. Faculty of animal Science, Bogor Agricultural University, Bogor, Indonesia. Cited from http://agtr.ilri.cgiar.org/index.php?option=com_content\&task=view\&id=91\&Itemid=108. Accessed 30-11-2018.

McDougal, T., 2018. SEA: Growing interest in cage free egg production. Poultry World. Oct 10, 2018. Available at https://www.poultryworld.net/Eggs/Articles/2018/10/SEA-Growing-interest-in-cagefree-egg-production-344557E/?cmpid=NLC|worldpoultry|2018-1010|SEA:_Growing_interest_in_cage_free_egg_production. Accessed 25-11-2018.

Nataamijaya, A.G., Abubakar, Saefudin, Y., Haryono, 1996. Selection for increasing of local chicken in Villages, Research Report. Research Institute for Animal Production In Indonesia. Cited from http://agtr.ilri.cgiar.org/index.php?option=com_content\&task=view\&id=91\&Itemid=108. Accessed 30-11-2018.

Phillips, C., 2016. UQ develops ASEAN poultry welfare standards - Good animal husbandry practices are gaining recognition. UQ (University of Queensland), June 29, 2016. Available at https://www.uq.edu.au/news/article/2016/06/uq-develops-asean-poultry-welfare-standards. Accessed 5-12-2018.

Premier, R., 2014. ASEAN-Australia Development Cooperation Program Phase II - ASEAN Good Animal Husbandry Practices For Layers and Broilers - Strategic Plan 2014-2016. Australian Aid. Available at http://www.asean.org/storage/images/Community/AEC/AMAF/OtherDocuments/ASEAN\%20Strate gic\%20Plan\%20GAHP\%20for\%20Layers\%20and\%20Broilers\%202014-2016.pdf. Accessed 25-112018.

Santoso, B., 2016. Indonesia's Growing Appetite for Animal Protein. Available at https://www.dbs.com/id/treasures-

id/aics/pdfController.page?pdfpath=/content/article/pdf/AIO/160307_insights_growing_appetite_f or_animal_protein.pdf . Accessed 24-11-2018.

Siagiaan, P.H., 2014. Pig production in Indonesia. Available at http://www.angrin.tlri.gov.tw/English/2014Swine/p175-186.pdf. Accessed 3-12-2018.

The Poultry Site, 2018. Asian food industry leaders put animal welfare on their agenda. The Poultry Site. April 23, 2018. Available at http://www.thepoultrysite.com/poultrynews/40008/asian-foodindustry-leaders-put-animal-welfare-on-their-agenda/ . Accessed 25-11-2018.

The Straight Times, 2018. Indonesia works to ban trade of dog meat, The Straight Times, Aug 7, 2018. Available at https://www.straitstimes.com/asia/se-asia/indonesia-works-to-ban-trade-ofmeat-from-pets-exotic-animals. Accessed 3-12-2018.

UkrAgroConsult, 2017. Indonesia should grow more pig, pork exporters. Blackseagrain, Sept. 25, 2017. Available at http://www.blackseagrain.net/novosti/indonesia-should-grow-more-pig-porkexporters. Accessed 3-12-2018.

USDA Foreign Agricultural Service, 2018. [Query done on 8-11-2018 to retrieve production and trade data from 2016.] Available at https://apps.fas.usda.gov/psdonline/app/index.html\#/app/advQuery. Accessed 8-11-2018.

USAID, 2013. Indonesia's Poultry Value Chain - Costs, Margins, Prices, and Other Issues. Nathan Associates Inc. for USAID. Available at https://pdf.usaid.gov/pdf_docs/pbaaa047.pdf. Accessed 25-11-2018.

Van Emous, R. 2018 [Poultry sector in Indonesia]. Unpublished report. Wageningen Livestock Research.

Wahyono, N.D., Utami M.M.D., 2018. A review of poultry meat production industry for food safety in Indonesia. J. Phys.: Conf. Ser. 953 012125. Available at http://iopscience.iop.org/article/10.1088/1742-6596/953/1/012125/pdf. Accessed 24-11-2018.

WAP (World Animal Protection), 2014. Indonesia. Available at http://api.worldanimalprotection.org/country/indonesia. Accessed 21-11-2018.

Whitehead, R., 2018. Halal Industry - After almost 30 years' wait, is Indonesia's halal law coming too soon? Salaam - Global Islamic Economic Gateway. Feb. 13, 2018. Available at https://www.salaamgateway.com/en/story/after_almost_30_years_wait_is_indonesias_halal_law_ coming_too_soon-SALAAM13022018123903/. Accessed 24-11-2018. 
Wikipedia, 2018. Animal welfare and animal rights in Indonesia. Available at https://en.wikipedia.org/wiki/Animal_welfare_and_rights_in_Indonesia . Accessed 1-7-2018. Wright, T., Darmawan, B., 2017. Voluntary Poultry Report. USDA. Available at https://gain.fas.usda.gov/Recent\%20GAIN\%20Publications/Voluntary\%20Poultry\%20Report_Jaka rta_Indonesia_1-13-2017.pdf. Accessed 24-11-2018. 


\section{Australia}

\subsection{Introduction}

We requested participation of several contacts, but failed to get anyone willing to provide information other than referring to informative websites of the ministry and the various sectors: Australian Egg Corporation Limited (AECL, https://www.australianeggs.org.au/), Australian Chicken Meat Federation (ACMF, https://www.chicken.org.au/) and Australian Pork Limited (APL, www.australianpork.com.au). Australia does not have a DFAS (Dutch Foreign Agricultural Service). A previous version of this chapter was reviewed by an anonymous NGO contact.

\subsection{Production and trade generally}

Australia recorded an impressive growth in exported volumes of beef between 2004 and 2015 with substantial gains on the EU market. Beef exports are an important part of the total country's trade (EC, 2107). Australia is a large country $\left(7.7\right.$ million $\mathrm{km}^{2}$ ) that is not heavily populated (24 million inhabitants; Strak, 2015a). It is one of the least populated countries in the world (Strak, 2015b).

\subsection{Animal welfare generally}

Australia's overall API (Animal Protection Index) score level was moderate (C on a 5 point scale; see Chapter 2 'Across countries' above; score $\mathrm{C}$ also for 'animals used in farming including transport and slaughter'). Its VACI rank, however, which tries to take into account not just animal protection, but also farm-animal production and consumption, was in the lower range, rank 44 out of 50 countries (see Annex 3, also for underlying scores related to national production and consumption levels based on FAO data).

Australia has no national law applying to animal welfare, but each state and territory has legislation that prohibits animal cruelty in their jurisdiction (links provided at RSPCA, No date-b). These welfare regulations, though broadly implementing OIE standards, to which Australia is an active participant and contributor (WAP, 2014), vary in the level of implementation and details. Fish and cephalopods, for example, are included in some, but excluded in other parts of Australia (WAP, 2014). (Note, however, that decapod crustaceans, such as crayfish, crabs, lobsters, prawns and shrimp, have a variable legal protection across the world, ranging from strong in Norway and New Zealand, through circumstantial in Australia and Italy, to non-existent in many other countries; Rowe, 2018). States and territories also differ regarding e.g. beak trimming and confinement such as battery cages and sow gestation stalls (WAP, 2014; Anon., Pers. comm.). Hence, standardisation of animal welfare at a national level has been called for (RSPCA, No date-c, No date-d; WAP, 2014).

With regard to the development of national legislation (see DAWR, No date), the current Model Codes of Practice (MCOP, e.g. concerning poultry, PISC, 2002a), which are essentially largely treated as guidelines, are being/to be updated and developed into national standards and guidelines (e.g. concerning cattle, see AAWSG, 2018a). The standards will be legally enforceable, while the guidelines will not be (but provide guidance on how to meet the standards). The poultry standards and guidelines are currently under development (AHA, 2017; AAWSG, 2018b; Bray, 2018). The pig standards have not yet started development, but are due to be started later this year (Anon., Pers. comm.). are currently under development (AHA, 2017; AAWSG, 2018b; Bray, 2018). The pig standards have not yet started development, but are due to be started later this year (Anon., Pers. comm.). Currently, Model Codes of Practice (MCOP) for the Welfare of Animals are available (nationally) for, among others, pigs (PISC, 2008), poultry (PISC, 2002a), slaughter (PISC, 2002b) and land transport of poultry (PISC, 2006). A criticism has been that these guidelines essentially document existing management practices, and that compliance is generally voluntary. The MCOP may thus effectively 
provide legislative immunity for the practices described therein (Goodfellow, 2015). Law enforcement regarding animal welfare is done by the RSPCA and state/territory government officers (WAP, 2014). Australia did not subscribe to the universal declaration of animal welfare due to trade interests (WAP, 2014). There have been significant welfare problems with the live export of cattle and sheep from Australia intended for slaughter in other countries (WAP, 2014), and it remains an issue of concern (e.g. Animal Australia, No date; Hameleers, 2018). Australia is a major exporter of sheep and goat meat to the EU, and one of the leading exporters of live animals in the world. As such, it has been particularly affected by animal-welfare standards on long distance transport including its own regulations on the subject and the introduction of a supply-chain responsibility scheme for exporters (EC, 2017). Australia led a project, funded by the EU, to raise awareness of standards for slaughter and transport in South and South East Asia (EC, 2017). Also, the University of Queensland (Australia) developed poultry (layers, broilers and ducks) welfare guidelines for ASEAN (the voluntary Association of South East Asian Nations, incl. Indonesia and the Philippines), covering cruelty, welfare, biosecurity, product quality and the environment (Phillips, 2016).

Australia is one of the few countries outside the EU with CAS (Controlled Atmosphere Stunning) systems (EC, 2017). EU audits showed that compliance with EU standards on cattle welfare at the time of slaughter was generally in line with the requirements of Regulation (EC) No 1099/2009 (EC, 2017).

Inhumane methods of culling of (wild) animals are still in use in the country, including poisoned baits (e.g. using 1080 poison) and some forms of traps (WAP, 2014). In particular, the killing of kangaroos for (meat) export (and local consumption) is an Australian animal-welfare issue that has recently raised international concern, e.g. about how the joeys are killed (Zembla, 2018a, 2018b).

In Australia, the attention towards animal welfare grew in the last years also through the activities carried out by the RSPCA, which started its Approved Farming Scheme about twenty years ago, to promote animal welfare on farms. It is now the leading independent accreditation scheme dedicated to improving farm animal welfare in the country (RSPCA, 2016; RSPCA, No date-a). On the retail side, Aldi Australia, the third largest retailer in Australia after Woolworths and Coles, committed to an animal-welfare certification system, only selecting certified suppliers for beef, lamb and pork (EC, 2017). Coles and Woolworths are included in welfare benchmarking (Amos and Sullivan, 2018) and McDonald's Australia committed to only serve free-range whole eggs in their restaurants (Clements, 2016), as have many other companies to date (RSPCA, No date-e).

The Dutch city of The Hague did not allow the presentation of the Australian animal-rights-type documentary Dominion on a large screen in a shopping area, because it would show 'shocking images' of Australia's farming practices (of pigs, layers, broilers, turkeys, ducks, cattle, sheep, goats, fish, rabbits, mink, foxes, dogs (puppy farms), horses and camels) being presented as representative of intensive farming practices across the world, while farmers strongly reject this latter claim (Hoedeman, 2018; Mitchell, 2018; for the documentary itself see Aussie Farms, 2018).

\subsection{Layers}

\subsubsection{Production and trade}

In Chapter 2 'Across countries' above we reported that in 2016 the country had 16 million layers, producing 237.000 tonnes of eggs, of which 170.000 tonnes were exported (Windhorst, 2018; see also IBISWorld, 2018).

In Australia, the chicken layer industry, or egg industry, is an important intensive production sector. The egg industry has displayed strong growth over the past decade due to rising per capita consumption of eggs (a little over 200 eggs per year/person; Poultry Hub, No date-b).

The egg producers' website states that Australian egg farmers produce 16.9 million eggs every day to feed the nation, which is 6.2 billion eggs each year, produced by about 20 million hens (AECL, No date-a). Previously (until the 1980's), Australia had hen quotas, but now egg production operates as a free market. This means that larger producers are generally favoured because they can usually produce eggs at a lower cost (Poultry Hub, No date-b). 


\subsubsection{Welfare regulations}

Australia's MCOP are available for poultry (PISC, 2002a), slaughter (PISC, 2002b) and land transport of poultry (PISC, 2006).

The current welfare codes for poultry (PISC, 2002a) addresses items like trough space ( $>=10 \mathrm{~cm}$ per bird), nipple drinkers ( $>=2$ ), perches ( $>=15 \mathrm{~cm} /$ bird), light, blinkers/spectacles (to prevent feather pecking; allowed on veterinary advice) and space allowances (e.g. $550 \mathrm{~cm}^{2} /$ bird for caged layers up to $2.4 \mathrm{~kg}$ (vs $750 \mathrm{~cm}^{2}$ in the $\mathrm{EU}$ ), and $40 \mathrm{~kg} / \mathrm{m}^{2}$ for broilers (if mechanical ventilation is present). The welfare code on land transport of poultry (PISC, 2006) is intended as a guide. It, for example, recommends avoiding $>24 \mathrm{~h}$ deprivation periods (except for day-old chicks), a contingency plan and space allowances (for birds 1.6-2.2kg: $36 \mathrm{birds} / \mathrm{m}^{2}$, i.e. $\sim 126.3-173.6 \mathrm{~cm}^{2} / \mathrm{kg} ; 2.2-3 \mathrm{~kg}: 28 \mathrm{birds} / \mathrm{m}^{2}$, i.e. $\sim 119-162 \mathrm{~cm}^{2} / \mathrm{kg} ; 3-5 \mathrm{~kg}$ max 20 birds $/ \mathrm{m}^{2}$, i.e. $\sim 100-166 \mathrm{~cm}^{2} / \mathrm{kg}$ ), which are more or less similar to the EU requirements.

In the newly proposed MCOP, to be called standards and guidelines, for poultry, which is currently under review, beak trimming would still be allowed but not more than one-third of the upper and lower beaks may be removed (AHA, 2017). Battery cages would also be allowed (at $550 \mathrm{~cm}^{2} / \mathrm{bird}$ if < $2.4 \mathrm{~kg} ; \mathrm{AHA}, 2017)$, and types of cage (conventional, furnished, colony cages) are being discussed (PS\&GDG, 2016). The public consultation on the welfare codes for poultry received about 170.000 responses, indicating considerable public interest in poultry welfare in Australia (Bray, 2018). Topics of concern include the use of conventional/battery cages, mutilations (esp. beak trimming), moulting, stocking densities, light (esp. providing 10 rather than 5 lux and raising the dark period from 4 to 8 hours for broilers) and killing. Many submissions rejected battery cages (Anon., Pers. comm.) but the egg sector tended to support the continued use of cages for laying hens, citing decreased mortality and better health in cages. There was limited support for enriched/furnished cages. A key tension concerns the issue of whether poultry in current production systems have a 'life worth living' in Australia. An opinion poll of the Australian Veterinary Poultry Association (AVPA) indicated that $48 \%$ of respondents did not support phasing out conventional cages, and 26\% did (Bray, 2018). An RSPCA survey indicated that $80 \%$ of Australians would support a ban on cages (Bray, 2018). Over $50 \%$ of the eggs sold in Australian supermarkets are labelled as non-cage, and 50\% of Australians choose to buy cage eggs (Bray, 2018), but most processed eggs are still derived from hens in battery cages (Anon., Pers. comm.).

RSPCA Australia's standards require nests, perches, dry litter floor covering, more space to move for layers, and improved rearing of pullets. While they do not allow battery cages, the RSPCA standards do not require access to the outdoor or the use of veranda's/porches (RSPCA, No date-a; 2015). The scheme is voluntary and currently does not yet cover transport and slaughter (RSPCA, 2015).

\subsubsection{Practical conditions}

Most layers kept in Australia are kept in battery cages (Anon., Pers. comm.; RSPCA, 2016: 11 million out of 18 million layer hens), and these must meet some welfare provisions. For example, as of 2001 all new layer cages must provide $550 \mathrm{~cm}^{2}$ per hen (Hellström, 2012; PISC, 2002a). Layers in cages are housed in small groups - typically 5 or 6 per cage (AECL, No date-a).

Australia doesn't have layers in furnished/enriched cages (Anon., Pers. comm.).

Three main alternative production systems are free range, organic and barn systems (Poultry Hub, No date-a). Free range is most actively supported by welfare groups for egg production. The maximum stocking density for (using the label) free range is 10.000 birds per hectare of outdoor range (ACCC, 2018). (Note that this information standard is separate from the MCOP, which states $1500 \mathrm{birds} / \mathrm{ha}$, but is not obligatory.) Beak trimming is allowed in free range, but not (routinely) at day old and only under veterinary guidance (and when other treatments for feather pecking have been exhausted). About $10-15 \%$ of chicken produced is free range. Organic is less than $1 \%$ of total production (Poultry Hub, No date-a).

In addition to cage, free-range, barn-laid and organic egg production, backyard egg production is also common in Australia. Over the past 5 years, there has been increasing demand for free-range eggs due to welfare issues in cages (Poultry Hub, No date-b), following significant NGO lobbying and cagefree commitments by the two main retailers (Anon., pers. comm.). The industry is gradually moving from cages to free-range egg production (Poultry Hub, No date-b). 
Intensive production, which may include free-range in Australia, means large numbers of hens are kept in a small area. Today some farms have up to 500.000 hens in multiple level sheds (Poultry Hub, No date-b). The sheds for barn-laid hens have multi-tiered structures (AECL, No date-a). As with freerange sheds, barn hens have nest boxes where the eggs role out onto a conveyor, and the barn has automatic manure belts (AECL, No date-a).

\subsubsection{Trends}

The AECL (Australian Egg Corporation Limited) has a 3-step quality assurance system, called Egg Corp Assured (ECA: basic, core, comprehensive compliance; $A E C L$, No date-c).

The scheme addresses issues including food safety, quarantine and biosecurity, hen health and welfare, egg labelling and environmental sustainability. A farm accredited under ECA must be audited by an accredited third party auditor. ECA also requires that caged sheds are in accordance with the welfare code (PS\&GDG, 2016).

The Australian egg sector is investing in hen welfare R\&D, aiming for objective measurement of welfare outcomes and sound science (AECL, No date-b). For example, it produced a recent handbook on feather pecking (with involvement of Wageningen Livestock Research; Glatz and Runge, 2018). Since the 1990s there have been a number of government and market-led initiatives to improve the welfare of layer hens. The focus of these regulatory and market initiatives has been a shift away from the dominant battery-cage system to barn/aviary and free-range production systems. While government regulations have played an important role in some countries (e.g. the EU and some US states), this has been much less the case in Australia (Scrinis et al., 2017; for more information about the controversy over free-range eggs in Australia as described by Scrinis et al., 2017, see Annex 4). The MCOP for poultry (PISC, 2002a) specifies an outdoor stocking density of 1500 birds per hectare for free-range layers, but it also contains a loophole (of higher stocking densities allowed with mobile housing) that was used by commercial farmers to apply stocking densities of up to 30.000 birds/ha (Scrinis et al., 2017). In 2018 the controversy probably came to an end by a ruling setting the freerange limit at 10.000 birds/ha (ACCC, 2018). The government has also given green light to the certification of the Pasture Raised On Open Fields (PROOF) scheme, involving well-managed pastures, mobile housing and stocking densities generally below 2.500 birds/ha (McDougal, 2017a).

\section{$6.5 \quad$ Broilers}

\subsubsection{Production and trade}

As indicated above (in Chapter 2 'Across countries') the mean broiler production in Australia amounts to 1.1 million MT CWE, with an import of 12.000 MT CWE and an export of $30.000 \mathrm{MT}$. The domestic consumption is 1.1 million MT CWE (USDA, 2018; data from 2016).

The broiler industry is represented by the Australian Chicken Meat Federation (ACMF, No date-a). ACMF has a role in setting standards for animal welfare and provides information about the industry (ACMF, No date $b$, No date-c).

In 2016-2017 653 million chickens were slaughtered (1.2 million tonnes of chicken meat).

The chicken meat industry is mostly vertically integrated. The two largest integrations - Baiada Poultry and Inghams Enterprises - supply more than 70\% of Australia's meat chickens. Approximately 700 chicken farmers produce about $80 \%$ of Australia 's meat chickens under contract with one of the major integrations (ACMF, No date-c).

Exports amounted to 35.4 million tonnes (volume). The chicken meat consumption in 2016/17 was $48.8 \mathrm{~kg}$ per capita (and $27.7 \mathrm{~kg}$ pig meat, $8.7 \mathrm{~kg}$ sheep and 25.4 beef \& veal; ACMF, No date-b). The feed conversion ratio ( $\mathrm{kg}$ feed/kg live weight produced) was 1.8 in 2018 (showing a declining trend from 2.5 in 1975 and e.g. 2.02 in 2000; ACMF, No date-b).

\subsubsection{Welfare regulations}

The newly proposed Code for poultry, which is currently under review, allows a stocking density of up to $40 \mathrm{~kg} / \mathrm{m}^{2}$ (AHA, 2017). 
RSPCA Australia has made a welfare scheme, which encourages broilers to be active (RSPCA, No date). Over $63 \%$ of broiler production is RSPCA approved, which is more than 397 million chickens every year (RSPCA, 2016). The RSPCA scheme for broilers (RSPCA, 2013) requires, among other things, compliance to the Model Code (PISC, 2002a), a maximum stocking density of 34 birds $/ \mathrm{m}^{2}$ (for mechanically ventilated buildings, and 28 birds $/ \mathrm{m}^{2}$ for natural ventilation), $2.7 \mathrm{~m}$ of perches per 1000 birds, and a maximum of 4 birds in 1 hand during catching (in addition to other (generally less quantified) requirements related to e.g. enrichment, lighting and litter quality, Anon., pers. comm.). It does not require using slower growing breeds, nor outdoor access, and it specifies only few quantified conditions during transport and slaughter (other than provided for in the MCOP), e.g. it specifies a maximum food deprivation time of 18 hours prior to slaughter and a maximum suspension time before stunning of $60 \mathrm{sec}$., but it does not specify a maximum stocking density during transport or minimum electrical stunning settings during slaughter. Notably, it recommends CAS and also requires a functional Closed Circuit Television (CCTV) system.

\subsubsection{Practical conditions}

The Australian conventional systems for rearing broilers may be a bit more similar to the EU system than the systems used in the US, but, unlike the EU, concrete floors are rare/absent and broilers are grown larger in Australia (Anon., Pers. comm.).

ACMF describes a 'typical' conventional farm comprising 6 sheds housing up to 240.000 meat chickens at any one time and producing a total of 1.3 million birds a year across an average of 5.5 batches (ACMF, No date-c). Most used breeds are Ross (Aviagen) and Cobb, the same as are used right around the world. Most farms are intensive and highly mechanised. Commercial meat chickens are grown on the floor of large poultry barns. The floor of the barn is covered in an absorbent bedding material, such as wood shaving or rice hulls, which is referred to as "litter". The main production systems are generally referred to as conventional (barn), free-range and organic. A meat chicken farm will comprise several (2-12 or more) barns, each separated by a distance of between 12-15 metres. Barn sizes vary, but a typical new barn might be 150 metres long and 15 metres wide. Mechanical (e.g. tunnel) ventilation is used to control the indoor climate. Feed and water lines run the length of the barn. Low light levels are used to keep the flock calm and reduce injury. The mortality rate is about 4\% (see also Poultry Hub, No date-c). 'Thinning out' (multiple pick-up) is common in Australia. It may be done up to 5 times (between day 30 and 65). Birds are often harvested by 'pick-up' crews at night as it is cooler. Full cleanout of the barn is done after every flock or after every second or third flock. The floor bases are usually rammed earth or cement (ACMF, No date-c).

In free-range production systems, in addition to their barn, the chickens are able to access an outdoors area (or 'range') during daylight hours after they are old enough to deal with the outside temperatures and predation. This happens from about 21 days of age onwards. They also often have lower stocking densities inside the barn. The main certifier of free range chicken meat in Australia is Free Range Egg and Poultry Australia Ltd (FREPA). The standards are published on the website at www.frepa.com.au (ACMF, No date-c).

Organic broiler farming aims at avoiding the use of synthetic chemicals such as synthetic pesticides, herbicides, fertilisers and antibiotics. In addition to having access to an outdoors area, organic broilers have mostly organic feed ingredients, and cannot be given antibiotics or routine vaccinations (unless e.g. required by law or disease). In Australia chicken meat can be described as 'organic' without being certified by an organic association (ACMF, No date-c).

The RSPCA Approved Farming Scheme has many requirements, that partly reach beyond the current legal requirements, but the main differences include a lower maximum stocking density, perches and other enrichments (pecking objects), lighting, bedding management, and regular on-farm assessment to ensure compliance. Outdoor access is not necessary (ACMF, No date-c).

Currently, between $65-70 \%$ of Australia's meat chickens are RSPCA Approved; $18-20 \%$ is Free Range Egg and Poultry; about $78 \%$ is accredited to one or both of the above schemes; less than $1 \%$ is certified organic. The remainder (about $22 \%$ ) is not accredited under any of these schemes (ACMF, No date-c).

The maximum stocking density (inside the barns) is $28-40 \mathrm{~kg} / \mathrm{m}^{2}$ for conventional broilers, depending on the standard of the ventilation provided in barns; $28-30 \mathrm{~kg} / \mathrm{m}^{2}$ for free range, depending on the standard of the ventilation provided in barns for FREPA accredited barns; $28-34 \mathrm{~kg} / \mathrm{m}^{2}$ for RSPCA Approved broilers, depending on the standard of the ventilation provided in barns; and $25 \mathrm{~kg} / \mathrm{m}^{2}$ for 
organic broilers. Broilers are not beak/toe trimmed. Only RSPCA approved and organic broilers have perches (free range doesn't require it). The age at harvest is $35-65$ days, except for organic (where it is 65 - 80 days). The MCOP on Domestic Poultry and Land Transport Standards apply to all types of broiler production (ACMF, No date-c).

Poultry slaughterhouses are very large and highly mechanised operations. Australia's largest poultry processing establishment processes 104 million chickens per year (2 million chickens per week; ACMF, No date-c). All chickens are stunned and rendered insensible to pain prior to slaughter (ACMF, No date-e).

The Australian chicken meat industry has relatively low and improved levels of AMR (antimicrobial resistance). Since 2007 antibiotics are only used therapeutically and not for growth promotion (ACMF, No date-e).

The industry has developed a model welfare audit program containing provisions from the MCOP for poultry (PISC, 2002a) and transport (PISC, 2006) (ACMF, No date-e). Background information is also available, including e.g. an Animal Welfare Manual for Meat Chicken Farming (Barnett et al., 2008) and an explanation of how breeding has improved broiler welfare over the past decades (e.g. improved leg health and less ascites; ACMF, No date-e).

\subsubsection{Trends}

No notable trends were found.

\subsection{Pigs}

\subsubsection{Production and trade}

As indicated above (in Chapter 2 'Across countries') the mean pig production in Australia amounts to 5 million pigs (386.000 MT CWE production; 210.000 MT CWE imports and 38.000 MT CWE exports). The domestic consumption is 558.000 MT CWE (USDA, 2018; data from 2016).

Australia has very strict biosecurity rules, resulting in a 'super' animal health status. Pig semen, for example, cannot be imported from any country, and the import of grain is difficult (Strak, 2015b). Australia has around 1.500 pig farms and a sow herd of 255.000 animals, producing around (a modest) 20 pigs per sow per year (US: 24; EU 26-27 pigs/sow/year; Denmark: 30). While biosecurity may protect the industry from disease, it also seems to have limited progress in pig genetics (Strak, 2015b).

Australia has less than 50 abattoirs and 7 of these are export accredited. These (larger) plants slaughter and process $80 \%$ of all the pigs, with an average throughput of around 11.000 pigs per week (Strak, 2015b).

Australians annually consume around $23.5 \mathrm{~kg}$ of pork per person (Strak, 2015b).

Fresh pork ( $10 \%$ of total fresh meat retail consumption) is produced locally, but $2 / 3$ of processed pork is imported (Strak, 2015b; RSPCA, 2016: over 70\% of processed pork is imported, esp. from the US, Canada and Denmark, Strak, 2015b; EC, 2017).

The Australian pork industry is represented by Australian Pork Limited (APL). APL is a producer-run company that receives additional research funds from the government (Strak, 2015b).

\subsubsection{Welfare regulations}

Australia's Model Codes of Practice (MCOP) for the Welfare of Animals are available for pigs (PISC, 2008) and slaughter (PISC, 2002b). The codes for pigs are expected to be reviewed later this year (Anon., Pers. comm.).

A contact of the pig sector (APL; Kerr, Pers. comm.) stated "that producers comply with the Model Code, and have in many instances, implemented higher standards of animal welfare. Notably, is our voluntary gestation stall phase out, where sows are housed in groups from 5 days after mating until one week before farrowing. Today around $75 \%$ of sows are housing in groups according to this definition". However, there are many different practices, and APL is (only) confident that the APIQ $\vee($ accredited producers are compliant with the MCOP as they are independently audited once a year. APIQ $\vee \circledast$ (Australian Pork Industry Quality) is APL's quality assurance scheme which covers around 
$90 \%$ of production. (Kerr, Pers. comm.; APL, No date-a). As stated earlier, the MCOPs are not regulations but each state and territory uses these to frame their regulation. In some cases states and territories may choose to implement legislation that goes beyond the MCOP. This was the case for Tasmania and the ACT (Australian Capital Territory) when they chose to ban sow stalls a decade ago (Kerr, Pers. comm.).

The current MCOP for pigs (PISC, 2008), for example, 'requires' (i.e. recommends) that sow stalls must allow animals not to touch both opposite sides at the same time, and that stalls are no longer allowed other than for a maximum of 6 weeks into gestation after 10 years (i.e. as of 2018; Hellström, 2010 ; it is 4 weeks in the EU). Examples of space allowances: New sow stalls should be $0.6 \times 2.2 \mathrm{~m}$. Farrowing crates: $0.5 \times 2 \mathrm{~m}$. Sows in groups: $1.4 \mathrm{~m}^{2}$ (compared to $2.25 \mathrm{~m}^{2}$ in the EU). Pigs at $25 \mathrm{~kg}$ : $0.26 \mathrm{~m}^{2}$; at $120 \mathrm{~kg} 0.74 \mathrm{~m}^{2}$ (compared to $1.00 \mathrm{~m}^{2}$ in the EU). Castration beyond 21 days must be done by a veterinarian (compared to 7 days in the EU). A light level of 20 lux is recommended (40 lux is required in the EU).

Pigs on RSPCA Approved farms have the space to move, forage, socialise and explore. Sow stalls and traditional farrowing crates are not allowed, but outdoor access is not required (RSPCA, No date, 2011).

The RSPCA scheme (RSPCA, 2011) requires compliance with the pig welfare code (PISC, 2008), the code for land transport (PISC, 2006), and the slaughter code (PISC, 2002b). Castration, tail docking and routine teeth clipping are not allowed; $8 \mathrm{hrs}$ of light and $6 \mathrm{hrs}$ of continuous darkness must be provided, as is litter/bedding and a stocking density of $1.03 \mathrm{~m}^{2}$ for a pig weighing $100 \mathrm{~kg}\left(0.46 \mathrm{~m}^{2}\right.$ for a pig weighing $30 \mathrm{~kg}$ ), allowing lateral recumbency (RSPCA, 2011).

\subsubsection{Practical conditions}

The Australian pork industry (APL) has spent millions of dollars on research into how best to house pigs at various stages of growth (APL, No date-b). Three types of system are the indoor system, outdoor bred and free range. These systems are outlined in APIQ $\vee($. Around $90 \%$ of Australian pigs are housed indoors. In free range (about $5 \%$ of all sows in Australia) all pigs are kept outdoors all the time with access to shelter and bedding. Paddocks must be rotated with a crop-forage pasture phase before pigs can be returned to the paddock. Around 5\% of pigs are 'Outdoor Bred: Raised Indoors on Straw', i.e. the piglets are born in outdoor conditions (huts), and as weaners they are moved to large barns with deep-litter bedding such as straw or rice hulls (APL, No date-b).

Australia is one of the few countries that does not routinely castrate all male pigs (APL, No date-b). Many male pigs are immuno-castrated (EFSA, 2004). Ear notching is commonly used for the identification of pigs. Teeth clipping is also practiced (APL, No date-b).

The housing of sows has been controversial. The Australian pork industry has taken a world-leading position by voluntarily committing to phasing out sow stalls, meaning that sows will not be confined in stalls from 5 days after they are last mated until one week before farrowing, when they are moved into farrowing accommodation. A sow stall is roughly the length and width of a fully grown sow (a female breeding pig), and does not allow the sow to turn around or leave. The sow is traditionally housed in a stall for some or all of her pregnancy, which lasts for approximately 115 days. Up until recently, sow stalls were in wide use in the Australian pork industry, and had been for many years. The Australian pork industry has committed to voluntarily phasing out sow stalls (now around 75-91\% (see below), though it was supposed to be done by 2017; APL, No date-b). As stated above, today around $75 \%$ of sows are housed in groups according to this definition (Kerr, Pers. comm.). Farrowing crates are routinely used in the Australian pork industry (and internationally). While the industry has invested a significant amount of money in research looking at alternatives to the farrowing crate over many years, this research has not revealed a viable alternative ( $A P L$, No date-b).

APIQ $\vee \circledast$ certification requires that the welfare codes (PISC, 2007) as well as relevant state and federal legislation and the requirements of good agricultural practice are met (APL, 2017). APIQ $\mathbb{R}$ standards are outcome-focused and supported by performance indicators (APL, 2017). The scheme is based on input from a wide range of stakeholders (producers, scientists, QA and audit experts,

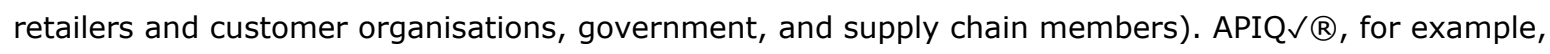
allows farmers to perform surgical castration until 21 days of age, and tail docking should not be done routinely (i.e. unless deemed necessary by a veterinarian and performed before 7 days of age by a vet or a trained person; APL, 2017). 
The Aussie Pig Farmers website (www.aussiepigfarmers.com.au), which is another website of the Australian pig sector, contains various disputable statements. For example, that 'a pig's tail does not have nerves for most of its length, so farmers only dock the tail where there are no nerves'. The website also notes that $80 \%$ of sows are housed in groups, and that 'there is now a $91 \%$ probability that sows will not be housed in sow stalls at any point in time between 5 days after mating and one week before farrowing' (a figure of $75 \%$ was communicated by Kerr, Pers. comm.).

\subsubsection{Trends}

No notable trends regarding pig welfare were found.

\subsection{References}

AAWSG (Australian Animal Welfare Standards and Guidelines), 2018a. Cattle - The Australian Animal Welfare Standards and Guidelines for Cattle. AAWSG. Last updated Aug. 10, 2018. Available at http://www.animalwelfarestandards.net.au/cattle/. Accessed 21-1-2019.

AAWSG (Australian Animal Welfare Standards and Guidelines), 2018b. Poultry. AAWSG. Last updated Dec. 18, 2018. Available at http://www.animalwelfarestandards.net.au/cattle/. Accessed 21-12019.

ACCC (Australian Competition \& Consumer Commission), 2018. ACCC releases guidance on free range egg standard. ACCC. Feb. 6, 2018. Available at https://www.accc.gov.au/media-release/acccreleases-guidance-on-free-range-egg-standard. Accessed 24-1-2019.

ACMF (Australian Chicken Meat Federation), No date-a. Australian Chicken Meat Federation. Available at https://www.chicken.org.au/. Accessed 8-12-2018.

ACMF (Australian Chicken Meat Federation), No date-b. Australian Industry Facts \& Figures. Australian Chicken Meat Federation. Available at https://www.chicken.org.au/facts-and-figures/. Accessed 812-2018.

ACMF (Australian Chicken Meat Federation), No date-c. Structure of the industry. Australian Chicken Meat Federation. Available at https://www.chicken.org.au/structure-of-the-industry/. Accessed 812-2018.

ACMF (Australian Chicken Meat Federation), No date-d. Chicken meat production. Australian Chicken Meat Federation. Available at https://www.chicken.org.au/chicken-meat-production/. Accessed 10-12-2018.

ACMF (Australian Chicken Meat Federation), No date-e. Chicken health and welfare. Australian Chicken Meat Federation. Available at https://www.chicken.org.au/chicken-health-welfare/. Accessed 1012-18.

AECL (Australian Egg Corporation Limited), No date-a. Learn About Egg Farming. Australian Egg Corporation Limited. Available at https://www.australianeggs.org.au/learn-about-egg-farming/. Accessed 6-12-2018.

AECL (Australian Egg Corporation Limited), No date-b. Animal welfare. Australian Egg Corporation Limited. Available at https://www.australianeggs.org.au/what-we-do/leadingresearch/category/animal-welfare. Accessed 6-12-2018.

AECL (Australian Egg Corporation Limited), No date-c. Egg Standards of Australia. Australian Egg Corporation Limited. Available at https://www.australianeggs.org.au/for-farmers/egg-qualitystandards/. Accessed 6-12-2108.

AHA (Animal Health Australia), 2017. Australian Animal Welfare Standards and Guidelines - Public consultation papers [for Poultry]. Available at http://www.animalwelfarestandards.net.au/poultry/poultry-public-consultation/. Accessed 8-122018.

Amon, N, Sullivan, R., 2018. The Business Benchmark on farm animal welfare - 2017 report. BBFAW (Business Benchmark on Farm Animal Welfare). Available at https://www.bbfaw.com/media/1506/bbfaw-report-interactive-amended-21st.pdf. Accessed 23-12019.

Animals Australia, No date. Animals don't belong here. Available at https://secure.animalsaustralia.org/take_action/live-export-shipboard-cruelty/. Accessed 8-122018. 
APL (Australian Pork Industry Limited), No date-a. Quality assurance. Australian Pork Industry Limited. Available at http://australianpork.com.au/industry-focus/product-integrity/qualityassurance/. Accessed 14-12-2018.

APL (Australian Pork Industry Limited), No date-b. Types of farming. Australian Pork Industry Limited. Available at http://australianpork.com.au/industry-focus/types-of-farming/. Accessed 14-12-2018.

APL (Australian Pork Industry Limited), 2017. APIQ (Australian Pork Industry Quality) standards manual. Australian Pork Industry Limited. Available at https://www.apiq.com.au/images/stories/2017_updates/apiq_standards_manual_version_4.3_7_2 017.pdf. Accessed 16-12-2018.

Aussie Farms, 2018. Dominion (2018) - full documentary [Official]. Directed by Delforce, C. Dominionmovement.com. Aussie Farms Repository. Oct. 10, 2018. Available at https://www.dominionmovement.com/watch. Also available at https://www.youtube.com/watch?v=LQRAfJyEsko. Accessed 23-1-2019.

Barnett, J.L., Edge, M.E., Thomson, L., Mackenzie, M., Sansom, G. Kite, V., 2008. National animal welfare standards for the chicken meat industry - Manual for Meat Chicken Farming. Available at https://chicken.org.au/wp-content/uploads/2017/09/ME-074-Chicken-Standards-Farming-Manual2.pdf . Accessed 10-12-1018.

Bray, H., 2018. Australian Animal Welfare Standards and Guidelines - Poultry. Independent Public Consultation Report. University of Adelaide. Available at http://www.animalwelfarestandards.net.au/files/2015/07/Public-consultation-report-final09072018.pdf. Accessed 4-12-2018.

Clements, M., 2016. Global appetite for poultry welfare rewarded. WattAgNet, July 20, 2016. Available at https://www.wattagnet.com/articles/27554-global-appetite-for-poultry-welfare-rewarded. Accessed 5-12-2018.

DAWR (Department of Agriculture and Water Resources), No date. Review of the Animal Welfare Standards and Guidelines Development Process. DAWR, Australian Government. Available at http://www.agriculture.gov.au/animal/welfare/standards-guidelines/review-animal-welfarestandards-and-guidelines-development-process. Accessed 20-1-2019.

EC, 2017. Study on the impact of animal welfare international activities. Brussels. Available at https://publications.europa.eu/en/publication-detail/-/publication/dc039353-ca9c-11e7-8e6901aa75ed71a1/language-en/format-PDF/source-49926262. Accessed 14-11-2018.

EFSA, 2004. Opinion of the Scientific Panel on Animal Health and Welfare on a request from the Commission related to welfare aspects of the castration of piglets. The EFSA Journal (2004) 91, 118. July 12 and 13,2004 . Available at https://efsa.onlinelibrary.wiley.com/doi/pdf/10.2903/j.efsa.2004.91. Accessed 24-1-2019.

Glatz, P., Runge, G., 2018. Australian Eggs Limited, North Sydney. Managing Fowl Behaviour handbook - A best practice guide to help manage feather pecking and cannibalism in pullet, layer and breeder flocks. Available at https://www.australianeggs.org.au/for-farmers/animal-carewelfare/. Accessed 6-12-2018.

Goodfellow, J., 2015. Animal welfare regulation in the Australian agricultural sector: A legitimacy maximising analysis. PhD. Macquarie University, Sydney, Australia. Available at https://www.researchonline.mq.edu.au/vital/access/manager/Repository/mq:45113. Accessed 191-2019.

Hameleers, R., 2018. Tweet]. Twitter. Available at https://twitter.com/reinekeeg4a/status/983228093262385152?s=11. Accessed 8-12-2018.

Hellström, J., 2010. Animal welfare (pigs) code of welfare 2010 report. National Animal Welfare Advisory Committee. Oct. 20, 2010. Available at https://www.mpi.govt.nz/protection-andresponse/animal-welfare/codes-of-welfare/. Accessed 14-11-2018.

Hellström, J., 2012. Animal welfare (layer hens) code of welfare report. National Animal Welfare Advisory Committee. Available at https://www.mpi.govt.nz/protection-and-response/animalwelfare/codes-of-welfare/. Accessed 5-12-2018.

Hoedeman, J., 2018. Den Haag neemt winkelend publiek in bescherming tegen 'schokkende dierenfilm' op megascherm. AD. Dec. 17, 2018. Available at https://www.ad.nl/binnenland/denhaag-wil-te-schokkende-bio-industriefilm-niet-op-megascherm-br a3a6027e/. Accessed 20-122018. 
IBISWorld, 2018. Egg Farming - Australia Market Research Report. May, 2018. IBISWorld.com. Available at https://www.ibisworld.com.au/industry-trends/market-research-reports/agricultureforestry-fishing/agriculture/egg-farming.html. Accessed 23-1-2019.

McDougal, T., 2017a. Australia leads the way for pastured egg producers. Poultry World. Dec. 1, 2017. Available at http://www.poultryworld.net/Eggs/Articles/2017/12/Australia-leads-the-way-forpastured-egg-producers-219365E/?cmpid=NLC|worldpoultry|2017-12-

01|Australia_leads_the_way_for_pastured_egg_producers. Accessed 5-12-2018.

McDougal, T., 2017b. Australian egg company faces record fine. Poultry World. July 26, 2017. Available at https://www.poultryworld.net/Eggs/Articles/2017/7/Australian-egg-company-facesrecord-fine-163594E/. Accessed 30-12-2018.

McDougal, T., 2018. Australian regulator defines free range egg standard. Poultry World. Feb. 12, 2018. Available at https://www.poultryworld.net/Eggs/Articles/2018/2/Australian-regulatordefines-free-range-egg-standard-247225E/?cmpid=NLC|worldpoultry|2018-02$12 \mid$ Australian_regulator_defines_free-range_egg_standard. Accessed 5-12-2018.

Mitchell, J., 2018 Dominion 'animal cruelty' documentary angers farmers - Video. FarmOnline National. April 5, 2018. Available at https://www.farmonline.com.au/story/5324513/industry-braces-fordocumentary-backlash-video/. Accessed 23-1-2019.

Phillips, C., 2016. UQ develops ASEAN poultry welfare standards - Good animal husbandry practices are gaining recognition. UQ (University of Queensland), June 29, 2016. Available at https://www.uq.edu.au/news/article/2016/06/uq-develops-asean-poultry-welfare-standards. Accessed 5-12-2018.

PISC (Primary Industries Standing Committee), 2008. Model Code of Practice for the Welfare of Animals: Pigs. PISC report 92. CSIRO Publishing, Collingwood, Australia. Available at http://www.publish.csiro.au/ebook/download/pdf/5698. Accessed 4-12-2018.

PISC (Primary Industries Standing Committee), 2002a. Model Code of Practice for the Welfare of Animals: Domestic Poultry. SCARM Report 83. CSIRO Publishing, Collingwood, Australia. Available at https://www.publish.csiro.au/book/3451/. . Accessed 4-12-2018.

PISC (Primary Industries Standing Committee), 2002b. Model Code of Practice for the Welfare of Animals: Livestock at Slaughtering Establishments. CSIRO Publishing, Collingwood, Australia. SCARM Report 79. Available at http://www.publish.csiro.au/ebook/download/pdf/2975. Accessed 4-12-2018.

PISC (Primary Industries Standing Committee), 2006. Model Code of Practice for the Welfare of Animals: Land transport of poultry. Second Ed. PISC report 91. CSIRO Publishing, Collingwood, Australia. Available at https://www.agric.wa.gov.au/sites/gateway/files/Model\%20Code\%20of\%20Practice\%20for\%20th e\%20Welfare\%20of\%20Animals\%20Land\%20Transport\%20of\%20Poultry\%20\%282nd\%20Edition \%29_0.pdf. Accessed 4-12-2018.

Poultry Hub, No date-a. Alternative poultry production systems. Available at http://www.poultryhub.org/production/industry-structure-and-organisations/alternative-poultryproduction-systems/. Accessed 5-12-2018.

Poultry Hub, No date-b. Chicken egg (layer) industry. Available at http://www.poultryhub.org/production/industry-structure-and-organisations/egg-industry/ . Accessed 5-12-2018.

Poultry Hub, No date-c. Meat chicken (broiler) industry. Available at http://www.poultryhub.org/production/industry-structure-and-organisations/chicken-meat/. Accessed 10-12-2018.

PS\&GDG (Poultry Standards and Guidelines Drafting Group), 2016. Poultry welfare standards and guidelines - Layer hen cages - Supporting paper public consultation version. Oct. 2016. Available at http://www.animalwelfarestandards.net.au/files/2015/07/Public-Cons-Version-Poultry-Layerhen-cage-support-paper-Oct-16.pdf. Accessed 8-12-2018.

Rowe, A., 2018. Should Scientific Research Involving Decapod Crustaceans Require Ethical Review? Journal of Agricultural and Environmental Ethics 31: 625-634. Available at https://link.springer.com/article/10.1007/s10806-018-9750-

7?wt_mc=alerts.TOCjournals\&utm_source =toc\&utm_medium =email\&utm_campaign=toc_10806_ 31_5. Accessed 28-12-2018.

RSPCA, No date-a. RSPCA Standards. RSPCA. Available at https://rspcaapproved.org.au/join/\#standards. Accessed 5-12-2018. 
RSPCA, No date-b. What is the Australian legislation governing animal welfare? RSPCA. Available at https://kb.rspca.org.au/what-is-the-australian-legislation-governing-animal-welfare_264.html. Accessed 20-1-2019.

RSPCA, No date-c. How can our animal welfare laws be improved? RSPCA. Available at https://kb.rspca.org.au/how-can-our-animal-welfare-laws-be-improved_503.html. Accessed 20-12019.

RSPCA, No Date-d. Should Australia have a national body to oversee animal welfare? RSPCA. Available at https://kb.rspca.org.au/should-australia-have-a-national-body-to-oversee-animalwelfare_708.html. Accessed 20-1-2019.

RSPCA, No Date-e. Cage free \& proud. RSPCA. Available at https://www.rspca.org.au/campaigns/layer-hen-welfare/cage-free-proud\#letter-n. Accessed 20-12019.

RSPCA, 2011. Pigs - RSPCA approved farming scheme standards. RSPCA Australia. Aug. 2011. Available at https://rspcaapproved.org.au/wp-content/uploads/2017/02/RSPCAPigsStandards.pdf.

RSPCA, 2013. Meat chickens - RSPCA approved farming scheme standards. RSPCA Australia. Available at https://rspcaapproved.org.au/wpcontent/uploads/2017/02/RSPCAMeatChickenStandards_May2013.pdf. Accessed 5-12-2018.

RSPCA, 2015. Layer hens - RSPCA approved farming scheme standards. RSPCA Australia. Available at https://rspcaapproved.org.au/wp-content/uploads/2017/02/RSPCALayerhensStandards.pdf. Accessed 5-12-2018.

RSPCA, 2016. RSPCA Approved Farming Scheme - Impact report 2016. RSPCA. Available at https://www.rspca.org.au/sites/default/files/2016-10-RSPCA-AFS-Impact-Report-web.pdf. Accessed 21-1-2019.

Scrinis, G., Parker, C., Carey, R., 2017. The Caged Chicken or the Free-Range Egg? The Regulatory and Market Dynamics of Layer-Hen Welfare in the UK, Australia and the USA. Journal of Agricultural and Environmental Ethics 30:783-808. Available at https://link.springer.com/article/10.1007/s10806-017-9699-y?no-access=true. Accessed 6-122018.

Strak, J., 2015a. Australia. Available at https://www.pigprogress.net/World-of-Pigs1/World-ofPigs/Country-focus1/?cmpid=ILC|Tool|C3_contentmarketing|in-article|in-article|countryfocus. Accessed 13-12-2018.

Strak, J., 2015b. Australia: Big in size but not in pigs. Pig Progress. June 21, 2016 (last update). Available at https://www.pigprogress.net/Finishers/Articles/2015/12/Australia-Big-in-size-but-notin-pigs-2737530W/. Accessed 13-12-2018.

USDA Foreign Agricultural Service, 2018. [Query done on 8-11-2018 to retrieve production and trade data from 2016.] Available at https://apps.fas.usda.gov/psdonline/app/index.html\#/app/advQuery. Accessed 8-11-2018.

WAP (World Animal Protection), 2014. Australia. Available at https://api.worldanimalprotection.org/country/australia. Accessed 21-11-2018.

Windhorst, H-W., 2018. Dynamics and patterns of the egg industry in APEC member countries. International Egg Commission. Available at http://1pfp2yazjqr27ku7g3h8zwwx-wpengine.netdnassl.com/wp-content/uploads/2018/07/Dynamics-and-patterns-of-the-egg-industry-in-APECmember-countries.pdf. Accessed 14-11-2018.

Zembla, 2018a. De jacht op de kangoeroe (Documentary). BNN Vara. Aug. 30, 2018 https://zembla.bnnvara.nl/nieuws/de-jacht-op-de-kangoeroe. Accessed 20-12-2018.

Zembla, 2018b. Waarom boycot Nederland geen kangoeroeproducten? BNN Vara. Sept. 5, 2018. https://zembla.bnnvara.nl/nieuws/waarom-boycot-nederland-geen-kangoeroeproducten. Accessed 20-12-2018. 


\section{$7 \quad$ New Zealand}

\subsection{Introduction}

We requested participation of several contacts in New Zealand, but failed to get anyone willing to provide information other than referring to (valuable) websites of the ministry. New Zealand does not have a DFAS. A previous version of this chapter was reviewed by an anonymous NGO contact. New Zealand has a population of 4.5 million people and consists of two main islands and some smaller islands. The country has a temperate climate in the South Island and a subtropical climate in the North Island. About $43 \%$ of the country's $269.000 \mathrm{~km}^{2}$ is used for agriculture, which employs roughly $32 \%$ of the country's population (Strak, 2017).

\subsection{Production and trade generally}

New Zealand is a firm supporter of free and open trade. It has one of the most open market economies in the world (Strak, 2017).

The dairy industry is of paramount importance for New Zealand's economy. It's also the only significant foreign supplier of dairy products to the EU, and a large exporter of beef and sheep and goat meat to the EU (EC, 2017; Hirsch, 2003).

New Zealand's geographical isolation provides protection to its livestock industry (e.g. resulting in a relatively high farm-animal health status and higher costs of importing fresh products), but it also makes it more difficult to export products, esp. fresh products (Hellström, 2012; Strak, 2017).

\subsection{Animal welfare generally}

Globally, the highest overall API (Animal Protection Index) score level (A) was given to New Zealand and several European countries (Austria, the UK and Switzerland; see Chapter 2 'Across countries' above). New Zealand's VACI rank, however, which tries to take into account not just animal protection, but also farm-animal production and consumption, was much less impressive, only rank 30 out of 50 countries (see Annex 3, also for underlying scores related to national production and consumption levels based on FAO data).

In New Zealand intensive farming is prevalent, particularly with poultry and pig production, but the use of sow stalls has been banned, and battery cages are phased out (VACI, no date-a; Strak, 2017; MPI, 2018f; PS\&GDG, 2016; MPI, 2018b).

Animal welfare is an area of key interest of New Zealand, perhaps even more so than it is in the EC (EC, 2017). In contrast to the EU, New Zealand has developed animal-welfare standards for dairy cattle (among other species) in their domestic legislation (EC, 2017; MPI, No date-a; No date-b). In 2015, explicit recognition was established that all animals are sentient (WAP, 2013; The Animal Welfare Amendment Act (No 2) 2015; MPI, 2016d). This is also reflected in concern for decapod crustaceans, which have 5 pairs of legs, an external skeleton and multiple nerve centres (ganglia) rather than a single brain (as in vertebrates). They include common seafood species such as crayfish, crabs, lobsters, prawns and shrimp. These characteristics make them difficult to empathise with and consequently legal protection of decapods ranges from strong (Norway and New Zealand), through to circumstantial (Australia and Italy) to non-existent (in many other countries; Rowe, 2018).

The Animal Welfare Act 1999 (MPI, 1999) and Animal Welfare (Care and Procedures) Regulations 2018 (MPI, 2018a) are supported by various Codes of Welfare that encourage compliance with standards above the minimum requirements. The Act establishes the fundamental obligations relating to the care of animals. Codes of Welfare expand on the basic obligations of the Act by setting minimum standards, and recommending best practices for the care and management of animals. Failure to meet a minimum standard in the Codes may be used as evidence to support a prosecution for an offence 
under the Act (Code of Welfare, 2018). The legislation formally recognises an independent National Animal Welfare Advisory Committee (NAWC) and a National Animal Ethics Advisory Committee (NAEAC; WAP, 2014). The New-Zealand Codes of Welfare (all recently updated in 2018) can be found on/via the website of the Ministry of Primary Industries (MPI, No date-a; no date-b). Codes of Welfare on slaughter, for example, state that priority should be given for slaughter of dairy-cattle calves, milk lambs and heavily lactating or pregnant animals (WAP, 2014).

The Customs Exports Prohibition (Livestock for Slaughter) Order explicitly prohibits all exports of livestock for slaughter unless approval is obtained. No application to export for slaughter has been made since the Prohibition Order has been in place (WAP, 2014).

Requirements on the stocking density of live bovine transported by sea are stricter in New Zealand compared to the EU (0.1-0.2 $\left.\mathrm{m}^{2}\right)$. The EU does not prohibit live exports to non-EU countries as does New Zealand (EC, 2017). The handling and stunning of the animals observed by the EU audit team was adequate in the slaughterhouses visited in New Zealand. New Zealand was the first Country recognised as fully equivalent at slaughter with EU standards within the framework of a cooperation forum on animal welfare (EC, 2017).

In the last decade, civil society has been a (if not the) major driver of progress in the field of animal welfare in New Zealand. A number of animal-welfare NGOs operate in the country. SAFE is the oldest animal-welfare NGO. It campaigns against factory farming, as well as against live animal exports. The New Zealand Society for the Prevention of Cruelty on Animals (SPCA NZ) has assumed an increasingly important role in supporting the government's activities in the enforcement of animal-welfare provisions. SPCA NZ has also had a key role in the development of private sector-led animal welfare standards and labelling, launching the SPCA Blue Tick $®$ standard (covering laying hens, pigs and broilers). Another NGO, the Bobby Calf Action Group, has been campaigning to ensure best practice handling and management of bobby calves (EC, 2017).

New Zealand is a very active OIE member, promoting animal welfare worldwide. The country also has a sustained interest in the development of private animal-welfare standards and labelling schemes (EC, 2017).

New Zealand's Animal Welfare Act (1999) includes in its definition of "animal" not only mammals, birds, and reptiles, but also amphibians, fish, crabs, crayfish, squid and octopus, and the Act specifies Codes of Welfare for circuses, rodeos, sheep and beef cattle, pigs, ostriches and emus, dairy cattle, laying hens, meat chickens, cats, dogs, horses and donkeys, llamas and alpacas, painful husbandry procedures and deer, slaughter of animals, temporary housing of companion animals, transport, and zoos (Hirsch, 2003; MPI, No date-b (2018)).

In the Welfare Code for domestic transport (MPI, 2018g) it has been specified, for example, that animals must not be transported with bleeding antlers or horn stumps, or within 7 days of being disbudded, dehorned, castrated, tail docked or having antler velvet removed, except yearling deer with approved rings. Also, stocking densities must be sufficient to allow animals to adopt a natural posture during the journey without injuring their heads or backs when standing, and to allow animals to rest, if this is necessary during the journey (but stocking densities do not seem to have been specified further).

A 2009 report on slaughter discusses the issue of bobby calves (MPI, 2009), and suggests, for example, that bobby calves be slaughtered within 28 hours of being loaded (and 30 hours since the last feed; and regulations of bobby calves too have recently been updated (MPI, 2018h). Another issue concerns whether horned cattle can be accepted for slaughter (due to the risk of injuries), and it is recommended that these animals be disbudded as calves. Another issue is the killing of farmed species without prior stunning. The report also discusses less conventional welfare issues such as the handling of foetuses in the case of slaughter of pregnant animals, the desliming of eels and stunning of crustaceans (MPI, 2009). Furthermore, 'clear' statements are made, e.g. that the welfare committee is "totally opposed on animal welfare grounds to the development of a Kosher export meat trade" (MPI, 2009).

The slaughter code applies to farmed mammals, birds, finfish, wild mammals and birds, finfish, crabs, lobsters and crayfish, and is consistent with the World Organisation for Animal Health (OIE) Guidelines for the slaughter of animals for human consumption.

The Welfare Code on painful husbandry procedures specifies that farmers may dock the tails of pigs until 7 days of age. Castration is not allow unless done by a veterinarian using pain relief. Dehorning of cattle is allowed only under local anaesthesia by a vet. Mulesing of sheep is prohibited (MPI, 2018d). 
A major reason to revise the codes and issue recent regulations (MPI, 2018) is to have a tool to address low to medium animal-welfare offences, thus filling the gap between the Codes and the Animal Welfare Act (1999). The new regulations are more specific than the Act, directly enforceable (unlike the Codes) and they specify penalties for low to medium offences (MPI, 2018e; see also Dymond, 2018).

A former colleague of the author at Wageningen Livestock Research lived in New Zealand for several years from 2010. Around that time negative publicity about sow stalls led to a self-ban by the sector. Biosecurity is an issue of major concern (e.g. fear of importing PRRS in pigs and various diseases in poultry, including Avian Influenza and Newcastle's Disease, and the eradication of tuberculosis in cattle). New Zealand has small pig and poultry sectors (the broiler sector is growing and there is some export; the pig sector is small and much pork is imported). The whole focus in New Zealand seems to be on dairy, and that is a vulnerability. Some years ago there was a scandal in China regarding NewZealand dairy and that had a big impact on the sector. A major problem are the bobby calves. Like Ireland, Chile and Australia (but unlike most other countries, Hutching, 2015), New Zealand has spring calving due to lack of arable land (resulting in a relative shortage of concentrate feed). This leads to a peak in labour requirements resulting e.g. in health issues and inadequate care. The peak of several million calves in spring implies that there is no constant production of calves. This makes it impossible to set up a viable veal industry. As a result, bobby calves are slaughtered and (some even) processed as 'waste' in the pet food industry. The bobby calves, therefore, seem to indicate a potential system error (Anon., Pers. comm.).

There are areas of concern in New Zealand where the climate is not ideal during certain seasons (stand-off pads for cattle and break feeding, Brennan, 2017). The South Island has a problem of cattle standing in mud and being fed kale (brassica leaves) in winter. Formerly, the hills were used for beef and lambs, but now, due to profitability, also to some extent for dairy. This leads to larger walking distances and problems associated with climate change (e.g. a dry summer resulting in the import of PKE, Palm Kernel Expeller, from Indonesia). Some parts of New Zealand often have drought problems ( 2 in the last 3 years) and do not have sufficient grass (Hutching, 2015). The system does not seem to be sustainable (Anon., Pers. comm.).

SAFE is one of the NGOs that has been campaigning to improve bobby-calf welfare (Safe, No date). They state that there are around two million calves killed soon after birth every year in New Zealand (Safe, No date). As cattle raised for meat and milk are different breeds from cattle raised for beef, there is not a high demand for the meat from dairy calves, so many go straight to slaughter. These calves are known as 'bobby calves' (SAFE, No date). There is little money in bobby calves, some are sold to pet food manufacturers, perhaps sometimes for as little as one dollar (SAFE, No date). Bobby calves must be at least 4 days old and in good condition before being sent to slaughter (SAFE, No date; MPI, 2018i; 2018j).

Biosecurity concerns may sometimes aggravate the bobby-calf issue, e.g. to reduce the spread of Mycoplasma bovis (Galloway, 2018). In an attempt to eradicate the disease, New Zealand is estimated to be killing about 152.000 cattle (McCullough, 2018).

In recent years the number of bobby calves sent to slaughter has declined to about 1.7 million in 2017 (Hutching, 2017; Galloway, 2018). Each year the number of calves born varies between 4.5 and 5 million (Hutching, 2017). Of those, about $40 \%$ are bobby calves, $30 \%$ are replacement calves and $30 \%$ are reared for beef. A small number - 31.000 in 2016 - are used for pet food (Hutching, 2017; Hutching, 2015). The drop in bobby-calf numbers was probably related to high beef prices, reduced herd size and public controversy (Hutching, 2017).

A recent survey commissioned by SAFE showed $60 \%$ of New Zealanders thought early slaughter of bobby calves was unacceptable, and $47 \%$ did not trust the dairy industry to treat bobby calves humanely (Hutching, 2017). SAFE also previously published footage of the ill treatment of bobby calves (Hutching, 2015).

The safeguard to ensure there is no ill treatment of calves is the national Animal Welfare Act that covers the welfare of all animals. Under that Act there are Codes of Welfare for on-farm, transport and processing. Veterinarians working for MPI (the Ministry for Primary Industries) oversee and audit the whole supply chain (Hutching, 2015). This includes an On Farm Verification (OFV) audit programme by veterinarians working for MPI (EC, 2017). MPI, however, was recently criticized by SAFE for having only 23 inspectors for animal welfare, and unable to respond to a cow left in hoisted clamps unattended for perhaps as long as 2 hours (Star, 2018). 


\section{$7.4 \quad$ Layers}

\subsubsection{Production and trade}

In Chapter 2 'Across countries' above we reported that New Zealand had 4 million layers, producing 59.000 tonnes of eggs (in 2016), and that 1.521 tonnes were exported and 40 tonnes were imported (in 2017) (Windhorst, 2018).

In 2016, there were 151 layer farms (of which 34 were using cage systems). The total flock size was 3.6 million birds, of which 2.4 million hens were kept in cages (Guthrie, 2016). Total production and consumption is about 1 billion eggs in 2010 (EPF, 2012 cited in Hellström, 2012; EPF, No date-c). Over $85 \%$ of eggs were sold as table eggs within the domestic market, with the remainder used in the baking and catering industries. Total egg production has slowly increased over the past decade (up to 2012), with an increase in per capita consumption to around 230 eggs per person annually (Hellström, 2012). Egg consumption in New Zealand is high by international standards. Eggs are seen as an important part of New Zealanders' diets, particularly in lower income families, as they are a relatively cheap source of high-quality protein (Hellström, 2012).

Conventional cages account for $44.7 \%$ of egg production (December 2018), but cages are to be replaced by 2022. Currently, the remaining eggs are being farmed in colony cage systems $(24.7 \%)$, barns and free-range (30.6\%). Organic eggs make up around $1 \%$ (EPF, No date-a).

New Zealand maintains a high avian health status with most of the major avian diseases being absent. New Zealand therefore has strict biosecurity controls with regard to importation of poultry and poultry products and is self-sufficient with regard to egg production and no table eggs were imported in 2012 (Hellström, 2012). Windhorst (2018), however, reported a small import volume of 40 tonnes in 2017 (see above).

\subsubsection{Welfare regulations}

Formerly, in 2003, two Codes of Welfare specifically addressed chickens: the "Code of Recommendations and Minimum Standards for the Welfare of Layer Hens" and the "Broiler Chicken Code of Welfare" (Hirsch, 2003). At that time, although the Act still permitted battery cages for hens at a density no longer allowed in Europe (450 $\mathrm{cm}^{2}$ per hen), the Animal Welfare Advisory Committee admitted to being "particularly concerned" about the use of battery cages, and suggested that alternative practices be implemented at the "earliest opportunity." Even so, New Zealand's minimum area per hen exceeded the common minimum used in the United States (Hirsch, 2003). Similarly, the Code at that time (in 2003) allowed debeaking and forced moulting, but also placed limits on the practices. For example, adult birds could not be debeaked, and no bird could go completely without food or water for more than 48 hours (Hirsch, 2003).

New Zealand's next layer-hen welfare code (of 2012) was phasing out conventional cages by the end of 2022. Cages had to provide at least $550 \mathrm{~cm}^{2}$ per hen for all cages from 1 January 2014, and colony cages had to provide at least $750 \mathrm{~cm}^{2}$ per hen or 13 hens per $\mathrm{m}^{2}$ (PS\&GDG, 2016).

Most recently, the revised codes were published (October 1, 2018; MPI, 2018b).

The code prescribes minimum standards (e.g. to have knowledgeable personnel) which are accompanied by example indicators (e.g. documentary evidence of staff training), recommended best practices and general (background) information. Examples of quantified minimum requirements include that newborn layer chicks should have access to food and water within 48 hours; that food must not be withheld for more than 12 hours before depopulation; 20 lux of light for layers; ammonia levels above 20 ppm require immediate action to be taken; every hen should be inspected at least once a day; beak tipping (removing $<2 \mathrm{~mm}$ of the beak using an infrared beam) is allowed until 3 days of age (unless done by a vet). The Code also recognises that chickens have a strong need to perform 'ancestral behaviours' including nesting, perching, scratching, dustbathing and wing flapping (MPI, 2018b).

Conventional battery cages (without perches or nextboxes) are still allowed (with minimum space allowances of 500-550 $\mathrm{cm}^{2}$ per hen depending on the building date of the cage system), but being phased out (between Oct. 2018 and Jan. 2023), after which dates enriched cages will be the new minimum standard (with e.g. a secluded nest area, at least $15 \mathrm{~cm}$ for perching per hen, and a minimum floor surface of $750 \mathrm{~cm}^{2}$ per hen or 13 hens per $\mathrm{m}^{2}$ ). Induced moulting is also banned (MPI, 2018b). The codes are the implementation of a 2012 report by NAWAC (Hellström, 2012). NAWAC did 
not believe that a compulsory transition to currently available barn or free-range systems would result in an increase in the overall welfare of layer hens. In NAWAC's assessment the, enriched, colony cages provide equivalent or superior overall welfare when compared with these other systems (Hellström, 2012).

\subsubsection{Practical conditions}

For several years the Egg Producers Federation (EPF) have been reporting on the transition away from conventional battery cages (e.g. Guthrie, 2016). At present (December 2018), conventional cages account for $44.7 \%$ of egg production, but cages are to be replaced by 2022 . The remaining eggs are being farmed in colony cage systems (24.7\%), barns and free-range $(30.6 \%)$ (see EPF, No date-b and No date-c, for videos of these systems). Organic eggs make up around $1 \%$ (EPF, No date-a). Colony cages have $750 \mathrm{~cm}^{2} /$ hen (rather than 550); 20-60 birds/colony (cage; max: 60 birds); nests, perches, scratching pads and a manure belt to remove droppings (EPF, No date-c). About $3 \%$ are barn eggs ( 7 hens/ $\mathrm{m}^{2}$; EPF, No date-d). Free-range has a maximum outdoor stocking density of 2.500 hens/ha and 9 hens $/ \mathrm{m}^{2}$ indoors (same as layers in the EU; EPF, No date-3).

\subsubsection{Trends}

The importance of poultry (meat and egg) welfare is increasingly recognised, not just in New Zealand, but across the world, e.g. McDonald's operations in New Zealand and Australia committed to only serve free-range whole eggs in their restaurants (Clements, 2016).

\subsection{Broilers}

\subsubsection{Production and trade}

The New Zealand broiler (meat chicken) industry is vertically integrated, with poultry processing companies often owning hatcheries and feed companies. There were a dozen poultry processing companies that contract poultry farmers to raise meat chickens (now probably less, Anon., Pers. comm.), and about 160 poultry farmers in 2008 (Poultry Industry Association of New Zealand (PIANZ), 2008, cited in Hellström, 2010).

In 2009 chicken meat consumption per capita averaged $30.4 \mathrm{~kg}$, with consumption of a total of 136.728 tonnes of chicken meat (around 80 million birds). Chicken meat consumption constitutes the highest percentage of meat consumed in New Zealand (36\%; Hellström, 2011). The Poultry Industry Association estimates 120 million chickens will be raised in New Zealand in 2019 (Hutching, 2018).

\subsubsection{Welfare regulations}

Most recently, the revised Codes were published (October 1, 2018; MPI, 2018c).

The Code prescribes minimum standards (e.g. to have knowledgeable personnel) which are accompanied by example indicators (e.g. documentation and staff training), recommended best practices and general (background) information. Examples of quantified minimum requirements include dark periods of at least 3 hours ( 4 hours in case of only 1 dark period in 24 hours); ammonia levels above 20 ppm require immediate action to be taken; stocking densities should remain below 38 $\mathrm{kg} / \mathrm{m}^{2}$; food must not be withheld from chickens for more than 12 hours prior to arrival at the processing plant; maximum stocking density during transport is $65 \mathrm{~kg} / \mathrm{m}^{2}$; if more than $1 \%$ mortality occurs within 24 hours, immediate action is required (MPI, 2018c). Note: light is not prescribed in lux levels though 20 lux is mentioned as an example indicator of the minimum standard (after the first 4 days of placement), and 50 lux is mentioned as a best practice (MPI, 2018c). Broilers must also have the opportunity to express their normal behaviours, including feeding, drinking, sleeping, preening, walking, scratching, ground pecking, leg stretching and vocalising (MPI, 2018c). 


\subsubsection{Practical conditions}

Two types of meat-chicken farming systems are used in New Zealand: Barn and Free-Range. In Barn systems, chickens are raised in large, open-plan poultry houses called "sheds", "houses" or "units". Sheds can be up to 150 metres long and 15 metres wide and hold up to 40.000 adult chickens. Sheds are equipped with automated temperature and ventilation controls and feed and watering systems and have litter (wood shavings) floors so they remain dry underfoot. Careful attention is given to the regulations relating to stocking densities in the Code of Welfare for meat chickens (according to PIANZ, the Poultry Industry Association of New Zealand; PIANZ, No Date-a).

A survey of New Zealand's commercial meat chicken farms by Bagshaw et al. (2006, cited in Hellström, 2011) showed that overall mortality of meat chickens was lower than the levels commonly observed in other countries and that the proportion of birds with severe leg weakness was about a quarter of that reported in several European countries. Overall, leg health of broilers in New Zealand was better than in Europe, indicating that good litter quality and good environmental control were being achieved (Bagshaw et al., 2006, cited in Hellström, 2011).

In New Zealand industry practice is for the catcher to kneel or stoop close to the ground when catching the chickens. This allows the chickens to be bunched in one hand whilst they are resting on their breasts on the litter. In addition, if a chicken starts flapping its wings while being carried to the transport crates, it is recommended that the bird be brought under control by either resting against the catcher's leg or by resting the bird on the ground (Hellström, 2011). Free-range broilers raised under the Blue Tick ${ }^{\circledR}$ programme have a maximum stocking density of $15 \mathrm{birds} / \mathrm{m}^{2}$ indoors, and at least 1.5 times the indoor-size outdoors (according to the farmer in the video 'Free-Range chicken farming in New Zealand, PIANZ, No date-a).

\subsubsection{Trends}

We found no information on this topic, but there is a lot of international pressure on meat chicken welfare (Anon., Pers. comm.). The broiler industry has two video's on its webpage related to health and welfare, both aiming to do myth-busting about the sector (no cages, no hormones, using antibiotics only therapeutically on a vet's prescription, no beak brimming; PIANZ, No date-b).

\subsection{Pigs}

\subsubsection{Production and trade}

As indicated above (in Chapter 2 'Across countries') the mean pig production in New Zealand amounts to 45.000 MT CWE, with an import of 62.000 MT CWE and no export. The domestic consumption is 107.000 MT CWE (USDA, 2018; data from 2016).

Pig farming is a small sector that has been a key area of development for New Zealand (2004-2015; EC, 2017).

As in other intensive agricultural sectors, in recent years pig farming in New Zealand has become more concentrated, moving from a structure typified by small businesses to an industry with fewer, larger participants who have made substantial capital investments (Hellström, 2010).

About $75 \%$ of the processed pig meat eaten in NZ is imported (Hellström, 2010).

New Zealand's imports of pig meat have increased, especially from the EU. A high proportion of imported pig meat is produced in countries that have far more intensive systems than New Zealand's standards. For example, in New Zealand, from December 2013 gestation stalls are not used at all during pregnancy. This is the whole pregnancy including the first 4 weeks. New Zealand, however, does not consider animal-welfare standards in setting trading conditions for imports (EC, 2017). New Zealand's pig industry has around 100 commercial pig farms. The sow herd is about 28.800 animals and these are divided roughly 50:50 between outdoor and indoor breeding units (Strak, 2017).

Sow productivity has increased over the last few years, to 13.1 liveborn piglets per sow in 2017 . The annual pig kill was about 662.000 animals with an average carcass weight of $71 \mathrm{~kg}$ (Strak, 2017). According to a recent benchmarking survey the output from indoor sows is 26.2 weaners/sow/year and 23 for outdoor herds. New Zealand's indoor sows have been group housed since December 2015. 
Around 13.000 sows are farmed outdoors and this reflects the emphasis on and interest in animal welfare (Strak, 2017).

The New Zealand producers' organisation, NZPork, is acutely aware that lower priced pork imports do not have to meet the same welfare standards as domestic producers and that this is a strategic threat to local producers. In 2010, NZPork implemented a welfare audit of the entire industry called 'PigCare ${ }^{T M}$ ', which is a requirement to allow locally-produced pork to be labelled as, '100\% NZ Pork, Ham or Bacon'. The 2010 Pigs Welfare Code required that after December 2015 pregnant animals must not be confined in stalls during gestation. The use of mating stalls for service was still allowed but for no more than one week (Strak, 2017).

The domestic pig kill over the period 2001-2017 has been fairly stable (at about 40-50.000 tonnes CWE), while imports have shown as steady increase (from 20.000 to $>65.000$ tonnes CWE in 2017; Strak, 2017).

Per capita consumption of pork is around $24 \mathrm{~kg}$ (Strak, 2017). Most of the imports are frozen pork and biosecurity concerns and geographical isolation have supported the survival of the domestic pig industry (Strak, 2017).

There are two major pig breeding companies operating in New Zealand, namely PIC NZ and Waratah Farms. Both companies import genetic material from overseas (USA or Norway; Strak, 2017). Pigs were not known in New Zealand until the European settlers brought them with them.

Nevertheless, New Zealand does have a native breed of pig, known as Kunekune, a small breed that descends from traders from Asia. It is often kept as a pet; in Maori language, 'kunekune' means 'fat and round' (Strak, 2017).

Pigs are, apparently, produced under animal welfare rules that are similar or equivalent to the European rules, and welfare is identified as being a possibly unique selling point for local producers (Strak, 2017).

New Zealand's large cattle herds and sheep flocks mean that the competitive position between pork, lamb and beef is a relevant consideration. Price comparisons between meat species tend to be unfavourable to pork - especially high-cost imported fresh pork. Thus, New Zealand's pig farmers may benefit from the presence of beef and sheep farmers (Strak, 2017).

\subsubsection{Welfare regulations}

Recently, the revised Codes of Welfare for pigs were published (October 1, 2018; MPI, 2018f). The Code prescribes minimum standards (e.g. to have competent personnel) which are accompanied by example indicators (e.g. evidence of training/competence), recommended best practices and general (background) information. Examples of quantified minimum requirements include that tail docking of pigs that are under 7 days of age must be carried out in a way that creates a clean cut and does not tear the tissue; tail docking of pigs that are 7 days of age or over and castration must be carried out by a veterinarian or a veterinary student under the direct supervision of a veterinarian throughout the procedure, and the pig must be given pain relief at the time of the procedure; clipping or grinding of needle teeth must be carried out before 5 days of age; the minimum unobstructed lying space allowance for grower pigs must be in accordance with the following formula: Area $\left(\mathrm{m}^{2}\right)$ per pig $=0.03$ $x$ liveweight ${ }^{0.67}(\mathrm{~kg})$ (this is e.g. $0.66 \mathrm{~m}^{2}$ for a pig of $100 \mathrm{~kg}$ body weight); immediate and appropriate action must be taken to reduce ammonia levels if they exceed $25 \mathrm{ppm}$ at pig level; pigs (i.e. sows) must not be confined to stalls unless - i) the confinement is for the purpose of mating; and ii) the confinement is for no more than 7 days per reproductive cycle; and iii) the pigs are released from the stalls as soon as practicable after mating; if individually confined in a pen, sows and gilts must have sufficient space so that they can stand up, turn around without touching the walls, and lie comfortably in a natural position, and must be provided with separate dunging, lying and eating areas; pigs must not be restrained by tethering; pigs, including piglets, must not be picked up or suspended by one front leg, ears or tail; pigs must not be struck or prodded with a goad in the udder, anus, genitals, or eyes; pigs must not be prodded in sensitive areas; electric prodders are allowed only for loading and unloading for transport or stunning pen when pigs are over $150 \mathrm{~kg}$; whipping of pigs is not allowed; pigs should be checked at least once daily; pigs should have sufficient light (e.g. 20 lux) for at least 9 hours each day (MPI, 2018f).

Above $21^{\circ} \mathrm{C}$, pigs require more space to be able to lose heat and maintain their body temperature. Therefore, the formula for pigs to be able to lie fully recumbent (Area $\left(\mathrm{m}^{2}\right)$ per pig $=0.047 \mathrm{x}$ liveweight ${ }^{0.67}(\mathrm{~kg})$ has been included as a recommended best practice (Hellström, 2010). 
With regard to behaviour the Code of Welfare states "Pigs must be managed in a manner that provides them sufficient opportunities to express and satisfy their normal behaviours. These include, but are not limited to, feeding, drinking, sleeping, dunging and urination, vocalisation, thermoregulation, and social contact." Note that it does not explicitly mention rooting or wallowing as 'normal behaviours' for pigs. As example indicators the Code states that less than $15 \%$ of pigs have skin lesions, bites and scratches from fighting at any one time, and as a best practice "rooting material such as straw, or other material that can be manipulated, should be provided for all pigs", and that "pigs with serious ear, vulva or tail bite wounds should be immediately separated from pen mates, where practicable, and treated if necessary" (thus note that this is only a 'best practice' and, in addition, formulated such that it would be difficult to enforce even if it were a minimum requirement (as farmers can often easily argue that it was not practicable or that they thought it was not necessary to separate the injured pig; MPI, 2018f).

NAWAC considered the issue of import substitution within the context of societal concerns about the use of stalls and of the welfare standards for pigs in New Zealand. NAWAC came to the majority view that, in spite of the risk of further import substitution, it could not ethically support the on-going use of dry sow stalls in New Zealand. NAWAC recognised there will be some loss of the welfare gain through import substitution and would like to minimise that, but has no relevant authority and its primary ethical and legislated concerns are about ensuring the welfare of New Zealand pigs. NAWAC has also changed the recommended minimum weaning age to 21 days and 28 days as a recommended best practice (Hellström, 2010).

Even though New Zealand's pork production is sold domestically only (and around 58\% of pig meat consumed by New Zealanders is imported), an animal-based welfare assessment programme PigCare $^{T M}$ has been operational since 2010. PigCare ${ }^{T M}$ is an on-farm accreditation programme (in addition to an assessment of the minimum standards in the Code of Welfare for pigs) set up with input from a number of stakeholders including farmers, veterinarians, government representatives, university personnel and NZPork (the farmer-funded industry body). This programme covers the whole commercial industry and applies across all types of production systems, both fully housed systems and farms practising outdoor breeding. Following concerted commitment from NZPork, it is now supported by all the major wholesalers and covers New Zealand's commercial production of an annual kill of 625.000 pigs (2015-2016). Besides, there are also some niche brands differentiated by particular production systems. For example, SPCA Blue Tick has an animal-welfare accreditation programme for free-range pigs and pigs raised in open sheds on straw or sawdust bedding (free farmed), which is licensed on a commercial basis. Free range pork comprises about $1.5 \%$ of the weekly kill (EC, 2017). NAWAC recognised the advantages of providing manipulatory material, such as straw. NAWAC would prefer to see advances made toward systems where straw can be provided to increase the welfare of pigs. However, a large number of housing systems used within New Zealand cannot currently cater for the presence of straw and other manipulable material due to the inability of the drainage systems to cope with this material. Hence, the provision of manipulable material has not been included as a minimum standard within the Code except for farrowing sows. However, provision of material that will enable pigs to perform rooting and exploration behaviours is important to ensure their good welfare and so this has been included as a recommended best practice (Hellström, 2010). NAWAC has recommended that manipulable material must be provided in any new farrowing systems and promotes as best practice that nest building material is provided for all sows (Hellström, 2010). NAWAC re-affirmed that the use of farrowing crates should be phased out eventually, but only when key criteria can be met, e.g. that alternatives allow New Zealand producers to remain competitive (Hellström, 2010). The New Zealand Pork Industry Board stated that the use of sow stalls is current good practice (Hellström, 2010). PigCare ${ }^{T M}$ is a 'world-leading welfare assurance programme for farmed pigs in New Zealand' (PigCare ${ }^{T M}$, No date). It requires compliance with the Code and specifies mostly open norms ("Pigs are cared for by a sufficient number of personnel..., etc.; PigCare ${ }^{\mathrm{TM}}$, No date).

\subsubsection{Practical conditions}

The market share of animal welfare-friendly products such as free-range eggs and crate-free pork in New Zealand is less than 5\% (Hellström, 2010).

Growing pigs are usually kept in the same group from weaning through to finishing, and during that time will have one or two shifts to larger pens (Hellström, 2010). 
The predominant form of housing for the farrowing/lactating sow is the farrowing crate. In New Zealand, $76 \%$ of sows were farrowing in crates, but only $68 \%$ were held in crates until weaning (Gregory and Devine, 1999, cited in Hellström, 2010). An estimated $41 \%$ of sows in New Zealand were housed outdoors (McIvor pers. comm. 2010, cited in Hellström, 2010). However, some outdoor sows may also farrow in crates (Hellström, 2010).

Surveys examining sow housing showed that larger producers tend to use dry sow stalls more than smaller producers (Gregory and Devine, 1999 cited in Hellström, 2010).

The Code of Welfare for pigs allows sows to be held in farrowing crates for 4 weeks postpartum and for up to 5 days prior to farrowing (MPI, 2016c).

Outdoor farrowing huts provide the best sow welfare but the worst piglet welfare (MPI, 2016c). Older (farrowing) crates are often too small to accommodate today's large sows (MPI, 2016c).

The (previous, i.e. 2010) Code of Welfare allowed for up to $5 \%$ of sows to be retained in crates for a further week (following the 4 week maximum in crates post-farrowing) as nurse sows (MPI, 2016c). It has been noted that industry does not accept or comply with this requirement and some producers are exceeding both the maximum $5 \%$ of sows allowed to be retained for this purpose and the amount of time that they are being retained (i.e. greater than the one week maximum as stated in the code; MPI, 2016c).

The (previous) Code also required that sows must be provided with material that can be manipulated until farrowing. It has been noted by NAWAC during the review that industry disagreed with this requirement and did not comply with this minimum standard (MPI, 2016c). It was anticipated that MPI would take compliance action to monitor these two aspects of the code during their upcoming inspection of all New Zealand's production pig farms (MPI, 2016c).

\subsubsection{Trends}

No information was found on this topic.

\subsection{References}

Brennan, J., 2017. Feedlots and intensive winter grazing - Review of literature and regional plans. Rural Advice - Horizons Regional Council Version 1 - August 2017. Available at http://www.horizons.govt.nz/HRC/media/Media/Supplementary-Documents/Strategy-PolicyCommittee-2018-1402/1816\%20Annex\%20A\%20Feedlots\%20and\%20intensive\%20winter\%20grazing\%20\%20review \%20of\%20literature\%20and\%20regional\%20plans.pdf. Accessed 14-3-2019.

Clements, M., 2016. Global appetite for poultry welfare rewarded. WattAgNet, July 20, 2016. Available at https://www.wattagnet.com/articles/27554-global-appetite-for-poultry-welfare-rewarded. Accessed 5-12-2018.

Dymond, N., 2018. The journey of animal welfare improvement: New Zealand's experience. Presentation at the EU platform meeting Nov. 11, 2018. Available at https://ec.europa.eu/food/sites/food/files/animals/docs/aw_platform_20181119_pres-13.pdf. Accessed 20-12-2018.

EC, 2017. Study on the impact of animal welfare international activities. European Commission, Brussels. Available at https://publications.europa.eu/en/publication-detail/-/publication/dc039353ca9c-11e7-8e69-01aa75ed71a1/language-en/format-PDF/source-49926262. Accessed 14-112018.

EPF (Egg Producers Federation), No date-a. Egg farming in NZ. Egg Producers Federation. Available at https://eggfarmers.org.nz/egg-farming-in-nz. Accessed 15-3-2019.

EPF (Egg Producers Federation), No date-b. Farming affordable and welfare-friendly eggs for New Zealand (incl. video of colony cag, free-range and conventional cage). Egg Producers Federation. Available at https://eggfarmers.org.nz/. Accessed 15-3-2019.

EPF (Egg Producers Federation), No date-c. The colony-cage environment (incl. video). Egg Producers Federation. Available at https://eggfarmers.org.nz/egg-farming-in-nz/farming-types/colonies. Accessed 15-3-2019.

EPF (Egg Producers Federation), No date-d. Barn. Egg Producers Federation. Available at https://eggfarmers.org.nz/egg-farming-in-nz/farming-types/barn. Accessed 15-3-2019. 
EPF (Egg Producers Federation), No date-e. Free-Range. Egg Producers Federation. Available at https://eggfarmers.org.nz/egg-farming-in-nz/farming-types/free-range. Accessed 15-3-2019.

Galloway, J., 2018. More bobby calves face slaughter as fewer calves likely to be raised from farmer concerns about Mycoplasma bovis. Stuff.co.nl. June 8, 2018. Available at https://www.stuff.co.nz/business/farming/104488775/more-bobby-calves-face-slaughter-asfewer-calves-likely-to-be-raised-from-farmer-concerns-about-mycopasma-bovis. Accessed 22-122018.

Guthrie, M., 2016. Cage transition report. Egg Producers Federation. Dec. 2016. Available at https://www.mpi.govt.nz/protection-and-response/animal-welfare/codes-of-welfare/. Accessed2312-2018.

Hellström, J., 2010. Animal welfare (pigs) code of welfare 2010 report. National Animal Welfare Advisory Committee. Available at https://www.mpi.govt.nz/protection-and-response/animalwelfare/codes-of-welfare/. Accessed 12-11-2018.

Hellström, J., 2011. Animal welfare (meat chickens) code of welfare report. National Animal Welfare Advisory Committee. Available at https://www.mpi.govt.nz/protection-and-response/animalwelfare/codes-of-welfare/. Accessed 12-11-2018.

Hellström, J., 2012. Animal welfare (layer hens) code of welfare report. National Animal Welfare Advisory Committee. Available at https://www.mpi.govt.nz/protection-and-response/animalwelfare/codes-of-welfare/. Accessed 12-11-2018.

Hirsch, V., 2003. Detailed Discussions of Legal Protections of the Domestic Chicken in the United States and Europe. Available at https://www.animallaw.info/article/detailed-discussion-legal-protectionsdomestic-chicken-united-states-and-europe. Accessed 21-12-2018.

Hutching, G., 2015. Q\&A: Bobby calves, New Zealand vs the rest of the world. Stuff.co.nz. Dec. 4, 2015. Available at https://www.stuff.co.nz/business/farming/74762096/qa-bobby-calves-newzealand-vs-the-rest-of-the-world. Accessed 22-12-2018.

Hutching, G., 2017. Number of bobby calves slaughtered declines as some farmers rethink. Stuff.co.nz. Nov. 28, 2017. Available at https://www.stuff.co.nz/business/farming/99335176/number-of-bobby-calves-slaughtereddeclines-as-some-farmers-rethink. Accessed 22-12-2018.

Hutching, G., 2018. Free range meat chicken claims fail to stack up. Stuff.co.nz. Oct. 25, 2018. Available at https://www.stuff.co.nz/business/farming/108078123/free-range-meat-chickenclaims-fail-to-stack-up. Accessed 16-3-2019.

McCullough, C., 2018. Mycoplasma NZ: 126,000 cows to be culled. Dairy Global. 29 May 2018. Available at https://www.dairyglobal.net/Health/Articles/2018/5/Mycoplasma-NZ-126000-cows-tobe-culled-289298E/?cmpid=NLC|dairy_global|2018-05-

31|Mycoplasma_NZ:_126,000_cows_to_be_culled. Accessed 30-12-2018.

MPI (Ministry of Primary Industries), No date-a. Animal Welfare. MPI. Available at https://www.mpi.govt.nz/law-and-policy/legal-overviews/animal-welfare/. See also https://www.mpi.govt.nz/protection-and-response/animal-welfare/. Accessed 21-12-2018.

MPI (Ministry of Primary Industries), No date-b. Codes of Welfare. MPI. Available at https://www.mpi.govt.nz/protection-and-response/animal-welfare/codes-of-welfare/. Accessed 24-2-2019.

MPI (Ministry of Primary Industries), 1999. Animal Welfare Act 1999. Available at http://www.legislation.govt.nz/act/public/1999/0142/59.0/DLM49664.html. Accessed 21-12-2018.

MPI (Ministry for Primary Industries), 2009. Animal welfare (commercial slaughter) - Code of Welfare report. April 22, 2009. National Animal Welfare Advisory Committee c/- MPI. Available at https://www.mpi.govt.nz/protection-and-response/animal-welfare/codes-of-welfare/. Accessed 21-12-2018.

MPI (Ministry for Primary Industries), 2016b. Code of welfare: Commercial slaughter. Dec. 16, 2016. National Animal Welfare Advisory Committee c/- MPI. Available at https://www.mpi.govt.nz/protection-and-response/animal-welfare/codes-of-welfare/. Accessed 21-12-2018.

MPI (Ministry for Primary Industries), 2016c. NAWAC review of the use of Farrowing Crates for Pigs in New Zealand. MPI. March 14, 2016. Available at https://www.mpi.govt.nz/protection-andresponse/animal-welfare/codes-of-welfare/. Accessed 2-1-2019.

MPI (Ministry for Primary Industries), 20016d. Animal Welfare Amendment Act (No 2) 2015 - Reprint as at 25 August 2016. Available at 
http://www.legislation.govt.nz/act/public/2015/0049/latest/DLM5174807.html. Accessed 24-22019.

MPI (Ministry of Primary Industries), 2018a. Animal Welfare (Care and Procedures) Regulations 2018. MPI. Available at http://www.legislation.govt.nz/regulation/public/2018/0050/latest/whole.html. Accessed 21-12-2018.

MPI (Ministry for Primary Industries), 2018b. Layer hens - Code of welfare. MPI. Oct. 1, 2018. Available at https://www.mpi.govt.nz/law-and-policy/legal-overviews/animal-welfare/. Accessed 21-12-2018.

MPI (Ministry of Primary Industries), 2018c. Meat chickens - Code of welfare. MPI. Oct. 1, 2018. Available at https://www.mpi.govt.nz/law-and-policy/legal-overviews/animal-welfare/. Accessed 21-12-2018.

MPI (Ministry of Primary Industries), 2018d. Painful Husbandry Procedures - Code of Welfare. MPI. Oct. 1, 2018. Available at https://www.mpi.govt.nz/law-and-policy/legal-overviews/animalwelfare/. Accessed 21-12-2018.

MPI (Ministry for Primary Industries), 2018e. Regulations and the animal welfare system. MPI. Nov. 22, 2018. Available at https://www.mpi.govt.nz/protection-and-response/animal-welfare/guideto-the-animal-welfare-care-and-procedures-regulations/regulations-and-the-animal-welfaresystem/. Accessed 22-12-2018.

MPI, (Ministry of Primary Industries), 2018f. Pigs - Code of Welfare. MPI. Oct. 1, 2018. Available at https://www.mpi.govt.nz/law-and-policy/legal-overviews/animal-welfare/. Accessed 22-12-2018.

MPI (Ministry for Primary Industries), 2018g. Transport within New Zealand Code of Welfare. Oct. 1, 2018. National Animal Welfare Advisory Committee c/- MPI. Available at https://www.mpi.govt.nz/protection-and-response/animal-welfare/codes-of-welfare/. Accessed 14-3-2019.

MPI (Ministry for Primary Industries), 2018h. Guide to the Animal Welfare (Care and Procedures) Regulations. MPI. Available at https://www.mpi.govt.nz/protection-and-response/animalwelfare/guide-to-the-animal-welfare-care-and-procedures-regulations/. Accessed 14-3-2019.

MPI (Ministry for Primary Industries), 2018i. Mortality rate in young calves in the 2017 spring calving season. MPI Information Paper No: 2018/01. MPI. Available at https://www.google.com/url?sa =t\&rct=j\&q=\&esrc=s\&source=web\&cd=1\&ved=2ahUKEwipitjmoIH hAhXLJIAKHZCrAmMQFjAAegQIBXAC\&url=https\%3A\%2F\%2Fwww.mpi.govt.nz\%2Fdmsdocument \%2F27675\%2Fsend\&usg=AOvVaw2Qwsa_e5dw3YuewmFO4qco. Accessed 14-3-2019.

MPI (Ministry for Primary Industries), 2018j. Bobby calf videos for transporters. MPI. Available at https://www.mpi.govt.nz/protection-and-response/animal-welfare/safeguardingprogramme/resources/bobby-calf-videos-for-transporters/. Accessed 14-3-2019.

PIANZ (Poultry Industry Association of New Zealand), No Date-a. Farming. PIANZ. Available at https://www.pianz.org.nz/who-we-are/farming/. Accessed 16-3-2019.

PIANZ (Poultry Industry Association of New Zealand), No Date-b. Health \& welfare. PIANZ. Available at https://www.pianz.org.nz/who-we-are/health-welfare/. Accessed 16-3-2019.

PigCare, No Date. What is PigCare ${ }^{\mathrm{TM}}$ ? Available at https://www.pigcare.co.nz/what-is-pigcare/. Accessed 16-3-2019.

PS\&GDG (Poultry Standards and Guidelines Drafting Group), 2016. Poultry welfare standards and guidelines - Layer hen cages - Supporting paper public consultation version. Oct. 2016. Available at http://www.animalwelfarestandards.net.au/files/2015/07/Public-Cons-Version-Poultry-Layerhen-cage-support-paper-Oct-16.pdf. Accessed 8-12-2018.

Rowe, A., 2018. Should Scientific Research Involving Decapod Crustaceans Require Ethical Review? Journal of Agricultural and Environmental Ethics 31: 625-634. Available at https://link.springer.com/article/10.1007/s10806-018-97507?wt_mc=alerts.TOCjournals\&utm_source=toc\&utm_medium=email\&utm_campaign=toc_10806_ 31_5. Accessed 28-12-2018.

SAFE, No date. Bobby Calves. Available at https://safe.org.nz/bobby-calves . Accessed 22-12-2018.

Star, G. 2018 Watch: MPI investigates cow clamping. NZ Harald. October 18, 2018. Available at https://www.nzherald.co.nz/the-country/news/article.cfm?c_id=16\&objectid=12144559. Accessed 12-11-2018.

Strak, J. 2017. New Zealand's pig industry: Surviving through isolation. Pig Progress. Oct 20, 2017. Available at http://www.pigprogress.net/World-of-Pigs1/Articles/2017/10/New-Zealands-pig- 
industry-Surviving-through-isolation-200451E/?cmpid=NLC|pigprogress_focus|2017-12-

13|New_Zealand?s_pig_industry:_Surviving_through_isolation. Accessed 12-11-2018.

USDA Foreign Agricultural Service, 2018. [Query done on 8-11-2018 to retrieve production and trade data from 2016.] Available at https://apps.fas.usda.gov/psdonline/app/index.html\#/app/advQuery. Accessed 8-11-2018.

VACI, No date-a. New Zealand. Available at https://vaci.voiceless.org.au/countries/new-zealand/ . Accessed 13-11-2018.

WAP (World Animal Protection), 2013. World Animal Protection applauds NZ'S recognition of sentience. WAP, May 2, 2013. Available at https://www.worldanimalprotection.org.nz/news/worldanimal-protection-applauds-nzs-recognition-sentience. Accessed 16-3-2019.

WAP (World Animal Protection), 2014. New Zealand. Available at

https://api.worldanimalprotection.org/country/new-zealand. Accessed 21-11-2018. 


\subsection{Introduction}

Besides information collected via internet searches, information on the poultry sector in Turkey was kindly provided by the DFAS and by Prof. Sabuncuoğlu Çoban (Faculty of Veterinary Medicine, Atatürk University, Erzurum, Turkey). She answered the questionnaire in considerable detail and for this also consulted academics, producers, the Turkish Statistical Institute and several publications, esp. BESD$\operatorname{BIR}(2017 a, b)$ and Yum-Bir $(2017 a, b)$.

Since Turkey is a Muslim country, pig production has been screened only in more general terms.

\subsection{Production and trade generally}

Turkey has one of the largest livestock populations in the world ( $\sim 4$ million farms, mostly mixed croplivestock, $2 / 3<5$ ha; Yilmaz and Wilson, 2012). Most farms are small in size (backyard farming) and well adapted to the natural environment (Yilmaz et al., 2012).

Most farmed species have been declining since the middle of the 20th century with the exception of (intensively-farmed) poultry that have greatly expanded (from 30 million in 1960 to 234.1 million in 2009 (of which $98.3 \%$ are chickens, including 30\% layers and 70\% broilers). Major poultry producers in Turkey are vertically integrated (Özertan et al., 2013).

Turkey is an important trading partner for the EU. It's one of EU's biggest importers of live cattle and cattle meat (Van der Horst, 2018).

\subsection{Animal welfare generally}

Turkey's overall API (Animal Protection Index) score level was very low (E on a 5 point scale; see Chapter 2 'Across countries' above; score D for 'animals used in farming including transport and slaughter'). Turkey's VACI rank, however, which tries to take into account not just animal protection, but also farm-animal production and consumption, was also in the lower range, rank 33 out of 50 countries (see Annex 3, also for underlying scores related to national production and consumption levels based on FAO data).

Turkey participated in EC animal welfare activities such as the international conference on the EU animal welfare strategy (in 2012), AWARE (2011 project to extend cooperation among universities), a research project on religious slaughter and TAIEX (capacity building of public administration e.g. on transport and slaughter of poultry; EC, 2017).

Turkey has the following regulations on animal welfare:

"Regulation for the minimum standards for the protection of layer chickens" (22/11/2014, No. 29183). "Regulation for general conditions for the welfare of farm animals" (which is in line with EU 98/58/EC). "Regulation for the welfare of farm animals".

"Regulation on the transport of live animals within the country" (24-12-2011, No.28152).

"Regulation on protecting animal welfare during their transport".

"Regulation on the control of animal transport and resting stations".

The Turkish regulations regarding poultry (layer) welfare, which are in line with the EC Directives, have a transition period until 1-1-2023. This means that e.g. conventional (unenriched) cages for laying hens with $550 \mathrm{~cm}^{2} /$ hen will be allowed until that date, unless the transition period is amended (DFAS, Pers. comm.).

About 1000 camels are used for camel wrestling, mainly in West Anatolia, and a scientific publication (Yilmaz et al., 2015) suggests the Turkish government should preserve this traditional event. 


\section{$8.4 \quad$ Layers}

\subsubsection{Production and trade}

The number of layers in Turkey is 121.3 million, producing 20.5 billion eggs, of which 350 million $\mathrm{kg}$ eggs were exported. This is a relatively substantial quantity relative to the country's total exports and compared to other countries (EC, 2017).

Breeds used for egg laying include both conventional and Turkish breeds (Lohhman white, Lohhman brown, Hy-line, Nick brown, Bovans, Isa brown and Atak-s; (Sabuncuoğlu Çoban, Pers. comm.). (Note that Turkey has developed 3 of its own layer hybrids for the industrial sector - named 'Atak', 'Atak-s' and 'Atabey'; Yilmaz and Wilson, 2012).

There are no welfare labels. It is not known how frequently farms are inspected by the Turkish Ministry of Food, Agriculture and Livestock. Options available to the inspection agency in case of noncompliance include administrative fines, decertification and farm closure (Sabuncuoğlu Çoban, Pers. comm.).

\subsubsection{Welfare regulations}

Turkey has specified standards (for enrichment, nests and perches, e.g. $15 \mathrm{~cm} /$ perch) similar to the EU, but the legislation has not been implemented yet. It has been postponed until 2023 and producers think they don't need such specifications (Sabuncuoğlu Çoban, Pers. comm.).

\subsubsection{Practical conditions}

The majority ( $\sim 95 \%$ ) of layer farms have battery cages (which do not have nests, perches, litter or other enrichment); $5 \%$ is organic or free range. Hens are kept at $450-550 \mathrm{~cm}^{2} / \mathrm{hen}, 16 \mathrm{hr}$ of light per day (50-100 lux). About $100 \%$ of the birds are beak trimmed. Moulting happens in $15-20 \%$ of the flocks (Sabuncuoğlu Çoban, Pers. comm.).

The maximum transport duration is $\sim 12 \mathrm{~h}$. Transport density is $\sim 40$ birds $/ \mathrm{m}^{2}$ (or $\sim 250-300 \mathrm{~cm}^{2} / \mathrm{bird}$ ). In Turkey electrical stunning of poultry has been common practice at slaughter for a long time, with consumers largely being unaware of this practice. The last 4-5 years, however, some new slaughterhouses have been built that claim to perform Halal slaughter of poultry, i.e. decapitation(/exsanguination) without stunning, but this is not mainstream (yet). Ruminants, in contrast to poultry, are generally slaughtered without prior stunning in Turkey (Sabuncuoğlu Çoban, Pers. comm.). The electrical stunning settings commonly involve low voltage, low amperage, medium frequency and long duration. This may negatively affect meat quality (Gezgin and Karakaya, 2016), and welfare. (Note that it has been common practice around the world to adjust electrical waterbath stunning settings in case of poultry slaughter to avoid meat quality issues (blood spots; Hindle et al., 2010). Since this has raised welfare concerns (inadequate stunning in addition to shackling), controlled atmosphere stunning (CAS, using CO2) is now prevalent in the Netherlands and increasingly so in the EU.).

\subsubsection{Trends}

One egg-producing company, Keskinoglu, was reported to be procuring enrichable cages (i.e. cages that can be converted into $100 \%$ EU compliant by removing the partition wall, providing for a so-call dark section for the hens to lay eggs in darkness, installing perches and "claw-shortening devices"; EC, 2017). 


\subsection{Broilers}

\subsubsection{Production and trade}

Broiler production is 2.2 million tonnes/year (slaughter weight: $2.3-2.4 \mathrm{~kg} / \mathrm{bird}$ ), of which. 425.000 tonnes is exported. Most used breeds are Ross, Hubbard, Cobb and Hybro. Welfare labels are not used, except for organic (Sabuncuoğlu Çoban, Pers. comm.).

The target for 2025 is to increase production up to 3 million tonnes (DFAS, Pers. comm.).

\subsubsection{Welfare regulations}

To our knowledge, Turkey has no specific standards for broilers.

\subsubsection{Practical conditions}

Broilers are housed in conventional, intensive housing conditions, i.e. in a large group in a barn on litter. Commonly used stocking densities are as follows: the first $1-5$ days: $40-50$ chicks/m²; $6-10$ days : $25-40$ birds $/ \mathrm{m}^{2} ; 11-16$ days $20-25$ birds $/ \mathrm{m}^{2} ;>17$ days: $15-20 \mathrm{birds} / \mathrm{m}^{2}$. At the end of the growing period ( $\sim 2$ days): $12-14$ birds $/ \mathrm{m}^{2}$, i.e. $\sim 30 \mathrm{~kg} / \mathrm{m}^{2}$. The maximum growth rate is 100 grams/day. A common lighting schedule is 23L:1D, 5-15 lux (little/no daylight. There is no other enrichment provided other than the litter on the floor (commonly wood shavings are used).

The maximum transport duration is $12 \mathrm{~h}$. Usually broilers are transported at a density of $110 \mathrm{~cm}^{2} / \mathrm{bird}$. Broilers are slaughtered by decapitation following electrical stunning. The prevalences of broken bones and foot pad dermatitis are not known. The prevalences for these conditions are probably similar to the EU (according to academic contacts in Turkey; Sabuncuoğlu Çoban, Pers. comm.).

\subsubsection{Trends}

No specific information was found on this subject.

\subsection{Pigs}

\subsubsection{Production and trade}

There are very few pigs in the country and these supply a small Christian community and the tourist trade. The lack of government attention may eventually lead to the disappearance of pigs from Turkey (Wilson et al., 2011).

\subsection{References}

BESD-BIR, 2017a. Beyaz Et Sanayicileri ve Damizlikcilari Birliǵi Derneǵi - Saǵlikli Tavuk Bilgi Platformu, NGRISI Kaya Belek - Antalya - Türkiye [BESD-BIR, 2017. Turkish Poultry Meat Producers and Breeders Association - Healthy Chicken Information Platform - Kaya Belek - Antalya - Turkey]

BESD-BIR, 2017b. Proceedings of the $4^{\text {th }}$ International Poultry Meat Congress. 26-30 April 2017. Kaya Palazzo Golf Resort \& Kaya Belek, Antalya Turkey.

EC, 2017. Study on the impact of animal welfare international activities. Brussels. Available at https://publications.europa.eu/en/publication-detail/-/publication/dc039353-ca9c-11e7-8e6901aa75ed71a1/language-en/format-PDF/source-49926262. Accessed 14-11-2018.

Gezgin, T., Karakaya, M., 2016. The Effects of Electrical Water Bath Stunning on Meat Quality of Broiler Produced in Accordance with Turkish Slaughter Procedures. Journal of Poultry Research 13: 22-26.

Hindle, V., Lambooij, E., Reimert, H.G.M., Workel, L.D., Gerritzen, M.A., 2010. Animal welfare concerns during the use of the water bath for stunning broilers, hens, and ducks. Poultry Science 
89: 401-412. Available at https://academic.oup.com/ps/article/89/3/401/1540221. Accessed 20$12-2018$.

Özertan, G., Saghaian, S., Tekgüç, H., 2013. Market Power in the Poultry Sector in Turkey. Available at https://www.academia.edu/5809605/Market_Power_in_the_Poultry_Sector_in_Turkey accessed 030918. Accessed 3-9-2018.

USDA Foreign Agricultural Service, 2018. [Query done on 8-11-2018 to retrieve production and trade data from 2016.] Available at https://apps.fas.usda.gov/psdonline/app/index.html\#/app/advQuery. Accessed 8-11-2018.

Yilmaz, O., Kor, A., Ertugrul, M., Wilson, R.T., 2012. The domestic livestock resources of Turkey: Goat breeds and types and their conservation status. Animal Genetic Resources 51: 105-116.

Yilmaz, O., Wilson, R.T., 2012. The domestic livestock resources of Turkey: Economic and social role, species and breeds, conservation measures and policy issues. Livestock Research for Rural Development 24.

Yilmaz, O., Coskun, F., Erdal Erturk, Y., Ertugrul, M., 2015. Camel wrestling in Turkey. Journal of Camelid Science 7:15.

Yum-Bir, 2017a. Yumurta Üreticileri Merkez Birliǵi [Turkish Egg Producers Association] Yumurta Tavukculugu Verileri [Egg Poultry Products Statistics].

Yum-Bir, 2017b. Öyleyse Her Sabah Yumurta [Every morning, an egg?] - Yumurta Üreticileri Merkez Birliǵi [Turkish Egg Producers Association] Guniz Sok. No. 35/2 Kavaklidere/Ankara (bilgi@yumbir.org)

Van der Horst, K., 2018. Rabobank: Turkije en China belangrijk voor rundvleesmarkt. Boerderij, May 24, 2018. Available at https://www.boerderij.nl/Rundveehouderij/Nieuws/2018/5/RabobankTurkije-en-China-belangrijk-voor-rundvleesmarkt-288217E/?cmpid=NLC|boerderij_vandaag|201805-24|Turkije_en_China_belangrijk_voor_rundvleesmarkt. Accessed 4-12-2018.

WAP (World Animal Protection), 2014. Turkey. Available at https://api.worldanimalprotection.org/country/turkey. Accessed 21-11-2018.

Wilson, R.T., Yilmaz, O., Ertugrul, M., 2011. The domestic livestock resources of Turkey: Pigs. The Pig Journal 66: 26-30. 


\section{$9 \quad$ The Philippines}

\subsection{Introduction}

We contacted an animal welfare organisation (PAWS) and the Bureau of Agriculture and Fisheries Standards, but, unfortunately, did not receive a response. Also, the Philippines do not have a DFAS (Dutch Foreign Agricultural Service).

The Philippines has a tropical marine climate. The country is usually affected by 15 typhoons and directly struck by 5 to 6 cyclonic storms each year. About $41 \%$ of the country is used for agriculture. Currently, the Philippines has a population of roughly 101 million, which grows $1.6 \%$ per year. The economy's growth rate is around 6\% per year (2011-2015; Strak, 2017). The poverty level is $22 \%$ (PSA, 2018b).

\subsection{Production and trade generally}

While farming is mostly small-scale, so-called factory farms are growing - particularly in pig and poultry production. There is concern that the Philippines will be a target for large-scale agribusiness, given tightening environmental regulations in Europe (VACI, No date-b).

Numbers of farm animals in the Philippines in 2018 included 12.6 million pigs, 60 million broilers, 36 million layers, 11 million ducks, 0.08 million native chickens (including backyard game fowl), 3.7 million goats and 5.5 million cattle (including Carabao, a domestic swamp-type water buffalo (Bubalus bubalis) native to the Philippines; PSA, 2018a).

People in the Philippines consume $28.8 \mathrm{~kg}$ of meat per year, including $14.2 \mathrm{~kg}$ of pork, $11.6 \mathrm{~kg}$ of chicken and $3 \mathrm{~kg}$ of beef or veal (Tomacruz, 2017).

The department of Agriculture appears to focus mainly on disease control (e.g. PRRS, PED, FMD (foot and mouth disease), Brucellosis, Classical Swine Fever in swine; AI and Newcastle in poultry), but also has programs on accreditation (poultry), genomics (pigs), native pigs/poultry, and organic livestock (pigs and poultry; BAI, 2018).

\subsection{Animal welfare generally}

The overall API (Animal Protection Index) score level for the Philippines was C (on a 5 point scale A-E; see Chapter 2 'Across countries' above; score $\mathrm{C}$ also for 'animals used in farming including transport and slaughter). Its VACI rank, however, which tries to take into account not just animal protection, but also farm-animal production and consumption, was very high, rank 4 out of 50 countries (see Annex 3, also for underlying scores related to national production and consumption levels based on FAO data).

The Animal Welfare Act of 1998 (also known as Republic Act 8485) made it unlawful for any person to torture any animal, to neglect to provide adequate care, sustenance or shelter, or maltreat any animals. It, for example, restricts the killing of non-farm animals, protects wildlife and bans dog and horse fighting, but e.g. greyhound racing and cockfighting are still legal (PAWS, No date-a, b). However, PAWS (Philippine Animal Welfare Society) has monitored more than a hundred cases of animal cruelty in the country a year, many of which are ignored due to the lack of effective penalties against animal abuse (PAWS, No date-a).

PAWS (founded in 1954) is a volunteer-based, non-governmental organization whose goal is to prevent animal cruelty through education, animal sheltering and advocacy. It is mainly concerned with pet welfare, including e.g. the dog meat trade, animal (dog, horse, cock) fighting, dog racing and (providing shelter for) stray animals (PAWS, No date-a). Cockfighting is still [in 2003] a popular and mainstream sport in Southeast Asia as well as in countries like Spain, Mexico and the Philippines. Worldwide, cockfighting is a billion dollar a year industry (Hirsch, 2003). 
The University of Queensland (Australia) developed poultry (layers, broilers and ducks) welfare guidelines for ASEAN (the voluntary Association of South East Asian Nations, incl. Indonesia and the Philippines), covering cruelty, welfare, biosecurity, product quality and the environment (see also below; Phillips, 2016).

Sus philippensis, a wild pig species, is now fully protected by Philippine law, though enforcement of protection measures is generally poor (Heaney and Meijaard, 2017).

An outbreak of bird flu led to hundreds of thousands of poultry being culled. In addition, people got scared and farm employees were reported to leave the poultry unfed (Gamil, 2017).

The 'Philippine Agricultural Engineering Standard' (PAES) 'for slaughterhouses for swine, small and large animals' has few welfare-related specifications. It prescribes, for example that for swine and small animals, a pre-slaughter pen and stunning boxes or $\mathrm{v}$-shaped restrainer-conveyors should be provided (PAES, 2000a).

The PAES for lairage prescribes, for example, that for swine, the space requirement should be $0.7 \mathrm{~m}^{2}$ per animal (above $100 \mathrm{~kg}$ ) and $0.6 \mathrm{~m}^{2}$ per animal (below $100 \mathrm{~kg}$ ); that the slope of the ramp shall not be greater than $25^{\circ}$ from the horizontal; that the floor shall be made of concrete and it shall be firm, non-slip, acid resistant, easy to clean and well drained; and that drinking water shall be provided and shall be available to animals. Each pen should be provided with a self-filling drinking trough (PAES, 2000b).

As regards a remarkable public perception somewhat related to animal welfare is the consumption of so-called balut, an 18-day-old fertilized duck egg (Calderon, 2014). The dish is particularly popular among Filipino families with ethnic Chinese backgrounds (Calderon, 2014).

\subsection{Layers}

\subsubsection{Production and trade}

In Chapter 2 'Across countries' above we reported that in 2016 the country had 90 million layers, producing 0.5 million tonnes of eggs (Windhorst, 2018; see also Jabbar, 2015; PSA, 2018a).

\subsubsection{Welfare regulations}

To our knowledge the Philippines has no specific (i.e. quantified) requirements on laying hen welfare comparable to the EU. The Bureau of Agriculture and Fisheries, however, has a Philippine National Standard (PNS) for good animal husbandry practices for chickens, covering both broilers and layers (BAFS, 2017a). It sets minimum requirements on e.g. the farm site (it should have a continuous supply of adequate power, potable water and a good access road; not be near bodies of water and wetlands that are frequented by migratory fowl; not be prone to flooding; not be near slaughterhouse facilities, etc.). Also, 'the chickens should be housed in a suitable structure', and 'the building should be designed and constructed using materials that: a) Should not cause any injury or impart hazard to the welfare of chickens' and there is 'appropriate space to feed and drink comfortably'. Pens should also be 'designed and constructed to prevent chickens from escaping; free from protruding objects or structures (e.g. nails and bolts) that may cause injury to the chickens and farm operators and farm workers'. These standards thus mostly contain so-called open norms (also e.g. proper ventilation, adequate lighting; sufficient pens and floor space; adequate feed). Another open norm is that 'the farm operator/worker should be responsible for the welfare of the chickens by giving adequate provisions so that they are able to perform at their optimum levels'. With respect to animal welfare specifically (Section 5.4.7), proper treatment is required to avoid suffering, sufficient food, water and space must be provided, and cruelty (e.g. maltreatment, neglect) to animals is not allowed. Reference is made to the OIE requirements regarding husbandry and killing of animals. In particular, adequate resources must be provided to maintain the live weight of the chicken within the normal physiological range for the species type, age and sex; it is not allowed to remove any part of the anatomy without adequate anaesthesia, or cause deliberate pain, suffering or distress when putting an animal to sleep (euthanasia, e.g. cervical dislocation), confine, handle or transport any chicken. The 5 freedoms are also acknowledged, and in this respect, for example, feed withdrawal is not allowed for more than 8 hours before slaughter. Also e.g. only clean and disinfected vehicles should be used to transport 
chickens, and transportation should be carried out at the coldest time of the day in order to avoid heat stress to chickens (BAFS, 2017a).

There are also good animal husbandry practices (GAHP) for layer and broiler production in the ASEAN region [which includes, among others, the Philippines, Australia, New Zealand and Indonesia], covering elements of biosecurity, workers' health and safety, animal welfare and measures to reduce environmental impact (Premier, No date-a). Many of the requirements in this GAHP are similar to the requirements in the PNS described above.

The ASEAN Good Animal Husbandry Practices (GAHP) for Layers and Broilers Food Safety Module (Premier, No date-a) served as a standard for countries with existing GAHP (Indonesia, Malaysia, Philippines, Singapore, Thailand and Vietnam) to start a harmonisation process (Premier, No date-b). The Philippine Government assisted the chicken meat and egg industry in a number of ways including the introduction of a GAHP code for the industry. The code is supported by an administrative order and was first adopted in 2008. Training of trainers and establishment of inspection teams, development of training manuals and the conduct of seminars and workshops occurred from 2009 to 2010 . This culminated in the granting of the first certificate in 2011. There are now many farms certified under this code. The code of GAHP aims to set out the general principles of good practice and the minimum requirements in the rearing/farming of animals. The code was primarily designed to help Philippine exporters meet the requirements of importing countries and has many elements of food safety risk minimisation in the broiler and egg industry; however it also has large components of general farm management (Premier, No date-b).

\subsubsection{Practical conditions}

A couple of YouTube videos show layers in conventional (i.e. unenriched) battery cages in the Philippines, e.g. in several layers/levels with 2 hens per cage in an open house (Le, 2017; Taylor, 2013). The latter also shows layer rearing on elevated, fully slatted, wooden floors in large pens (several hundred birds per pen; Taylor, 2013).

Effective temperature regulation is one of the most important success factors when it comes to egg production in the Philippines (Filipino Poultry, 2016). Optimal production requires a temperature between 11 and 26 degrees Celsius. At $26-28^{\circ}$ Celsius there is a little reduction in the feed intake; between $28-32^{\circ}$ Celsius the feed consumption is reduced and the level of water intake is increased in the poultry house. Also, the eggs produced are of reduced size and have thinner egg shells. Between $32-35^{\circ}$ Celsius there is slight panting and a further reduction in the feed intake. Between $35-40^{\circ}$ Celsius, the chickens begin to suffer from heat prostration. Over 40 degrees Celsius, the chickens suffer from heat stress and begin to die. Whenever there is a temperature rise beyond 28 degrees Celsius, there will be a decrease in production as well as in the quality of the eggs. Seasonal temperature changes in a country like the Philippines can result in up to $10 \%$ decrease in egg production (Filipino Poultry, 2016).

\subsubsection{Trends}

Dozens of farmers from across South East Asia (SEA) have attended the region's first dedicated workshop on cage-free egg production in Indonesia (McDougal, 2018).

Multinational companies with operations in Asia, such as Accor Hotels, Compass Group, Sodexo and Unilever are joined by Asian leaders such as Carrefour Taiwan, Grand Hyatt Singapore, Andaz Singapore, Salad Stop!, the Prive group and the Lo and Behold Group in committing to $100 \%$ cagefree egg supply chains. And as food and hospitality leaders around the world adopt cage-free egg policies, egg producers are transitioning to higher welfare animal production systems to meet the growing demand in the region. This includes major companies such as Charoen Pokphand Foods, Betagro of Thailand, San Miguel Corporation and Bounty Fresh of the Philippines (McDougal, 2018). 


\subsection{Broilers}

\subsubsection{Production and trade}

In Chapter 2 'Across countries' above it was reported that the mean broiler production in the Philippines amounted to 1.2 million MT CWE, with an import of 244.000 MT CWE and an export of 4.000 MT (USDA, 2018; data from 2016). The domestic consumption was 1.5 million MT CWE (USDA, 2018; data from 2016).

In 2017 the production volume of poultry meat was 1.7 million MT (live weight) and 0.3 million MT frozen chicken meat was imported. In total 1.1 billion chickens (broilers, native chickens and culled layers) were slaughtered in 2017. The 2018 inventory listed 60 million broilers (PSA, 2018a).

\subsubsection{Welfare regulations}

To our knowledge the Philippines has no specific (i.e. quantified) requirements on broiler welfare comparable to the EU. The Bureau of Agriculture and Fisheries, however, has a Philippine National Standard (PNS) for good animal husbandry practices for chickens, covering both broilers and layers (BAFS, 2017a; see above, under Layers - Welfare legislation).

\subsubsection{Practical conditions}

Broiler production in the Philippines may use tunnel ventilation to enhance air speed, and buildings must be designed to deal with high wind speeds associated with typhoons, e.g. using a construction made of steel (Molina, 2014).

Raising broilers in a climate controlled system (CCS) [with plastic slats overlaid flooring, nipple drinkers and tunnel ventilation] was tested at the Central Luzon State University (Salas et al., 2013). It compared conventional rearing [in an open house, on bamboo slatted floors and bell drinkers] and CCS housing from day-old to the 5th week up to a body weight of $1.6 \mathrm{~kg}$. With better feed conversion efficiency, uniformity of birds, and harvest recovery, the use of CCS resulted in a higher revenue per bird (Salas et al., 2013).

Another innovative system implemented in the Philippines is the BroMaxx system of Jansen Poultry Equipment. This is a broiler housing system that promises improved climate control, hygiene and animal health, and therefore better growth and a more uniform broiler flock with premium meat quality. The system is designed for high bird density (up to $50 \mathrm{~kg} / \mathrm{m}^{2}$ ) and smart harvesting methods result in significant labour savings. Antibiotic use is expected to diminish in this system, leading to improved food safety and human health. The BroMaxx system is a modern kind of battery cage for housing multiple (3) layers/levels of broilers kept in colony groups (of 60 birds per cage) on a flexible (nylon) floor (Van Emous, In prep.).

\subsubsection{Trends}

Several trends have been covered in the previous section.

\subsection{Pigs}

\subsubsection{Production and trade}

In Chapter 2 'Across countries' above it was reported that the mean pig production in the Philippines amounted to 1.5 million MT CWE; 195.000 MT CWE imports and 1.000 MT CWE exports; USDA, 2018; data from 2016). The domestic consumption was 1.7 million MT CWE (USDA, 2018; data from 2016). In 2017 the production volume of pigs was 2.3 million MT (live weight). In total 27 million pigs were slaughtered in 2017. The 2018 inventory listed 12.6 million pigs (PSA, 2018a).

The Philippine pig sector is growing. The swine sector is the second largest economic activity in the Philippines' agricultural sector (Strak, 2017). Most pigs are raised in Luzon, the most populated area which includes the capital Manila (Ter Beek, 2015a). Domestic pig production has been rising in both 
backyard and commercial farms. Backyard farms accounted for $64 \%$ of the total pig population. Approximately $35 \%$ of the total breeding herd ( 1.68 million sows) were on commercial farms (July 1 census 2016; Strak, 2017).

Although a lot of domestic pig meat is sold through wet markets (selling fresh meat and produce) there is a growing meat processing sector which serves foodservice, retail and export customers. The Philippines' Association of Meat Processors (Pampi) has around 50 company-members, and investment (of billions of US\$) in new production and processing capacity is evident (Strak, 2017). However, the domestic swine industry has a record of low productivity and has only recently begun expanding. A particular challenge is the high feed and energy prices, resulting in a relatively high cost of production (estimated at US\$ 1.80 per kg; Strak, 2017). The cost of pig production is also higher on the Philippine islands than in most surrounding countries esp. due to a compulsory $35 \%$ tax tariff, imposed by the Philippine government (Ter Beek, 2015a).

Although the Philippines have some significant export markets (mainly the Middle East) pig meat imports have grown steadily (up by circa $12 \%$ from the EU in 2016; Strak, 2017).

Germany and Canada were the largest suppliers. Pig meat imports are expected to continue, partly due to domestic consumption outpacing improvements to Philippine production systems (estimated at about 5\% in 2017). The dominance of "backyard" systems implies it is difficult to consistently meet the demand for quality products (Wilkins, 2017).

Reports of corruption and irregularities in customs processing are not uncommon as are complaints about unwieldy and bureaucratic SPS (Sanitary and PhytoSanitary measures) procedures and this may also be encouraging domestic investment (e.g. the Thai agribusiness Charoen Pokphand (CP) has already established itself in the Philippines, Ter Beek, 2015a). Also, the ever present threat of typhoons can seriously disrupt local production (Strak, 2017).

Under the auspices of the Bureau of Animal Industry (BAI) the swine industry's supply chain has signed up to a 26-page 'Hog Industry Roadmap'. The plan expresses the ambitious vision of a sustainable and globally-competitive hog industry by the year 2027. It envisages a growth of per capita consumption of pork in the Philippines from $14.9 \mathrm{~kg} /$ capita in 2015 to $16.4 \mathrm{~kg} /$ capita in 2027. This implies a growth of $+30 \%$ in the domestic herd (Strak, 2017). The number of pigs sold/sow/year is required to increase from 18.8 in 2015 to 30 in 2027, and the FCR (Feed Conversion Ratio) needs to shrink from 3.7 to 2.27 in the next decade (Strak, 2017).

\subsubsection{Welfare regulations}

To our knowledge the Philippines has no specific (i.e. quantified) requirements on pig welfare comparable to the EU. The Bureau of Agriculture and Fisheries, however, has a Philippine National Standard (PNS) for good animal husbandry practices for swine (BAFS, 2017b). It mostly sets open norms similar to those described above for chickens (BAFS, 2017a). For example, a pig farm should be compliant with laws and regulations, should have a continuous supply of adequate electrical power, should be located at least $5 \mathrm{~km}$ away from slaughterhouses and animal-holding facilities. Also, an optimum level of nutrition must be maintained at all times for proper functioning and well-being; water should be clean, potable, sufficient, and free from any hazardous substances; all persons entering the farm should take a shower, have their hair washed and wear protective clothing supplied by the farm. With respect to animal welfare specifically e.g. proper handling facilities and techniques are required to protect animals from fear, stress, pain and injury, and sick, injured or disabled animals should be given the necessary veterinary attention, including humane euthanasia if necessary. Sticks or canes should not be used to restrain the farm animals, but a stick or cane may be used for the worker's safety when handling larger or aggressive animals. Also, e.g. animals should be transported in appropriate vehicles (BAFS, 2017b).

In addition, the Philippines also have Agricultural Engineering Standards (PAES) concerning swine housing (PAES, 2001). It has minimum recommended space requirements, e.g. $0.85 \mathrm{~m}^{2}$ for $81-100 \mathrm{~kg}$ pigs. $0.35 \mathrm{~m}^{2}$ for $21-40 \mathrm{~kg}$, adult pigs in groups: $2.5 \mathrm{~m}^{2} / \mathrm{pig}$, gestating sows: $1.2 \mathrm{~m}^{2} / \mathrm{pig}$. (Note that the EU requirement is $2.25 \mathrm{~m}^{2}$ for sows in groups from 4 weeks after service.) It also has recommended slat widths (e.g. for finishers $10-20 \mathrm{~mm}$ slat spacing). Also, plastic flooring shall have a rough surface. Minimum farrowing crate dimensions are $1.8 \times 0.6 \mathrm{~m}$. Finishers should be kept in separate pens in groups of no more than 25 animals. Gestating sows should be either housed individually (in a box or stall) or in a group. For individual pens, the dimension should be $0.66 \mathrm{~m} \times 1.8$ $\mathrm{m}$. The recommended light level is 50 lux for growing and finishing pigs. The maximum temperature 
(recommended) is $30^{\circ} \mathrm{C}$ for growers, finishers and sows, and $35^{\circ} \mathrm{C}$ for newborn piglets. It is optional to provide water spray nozzles to provide cooling (PAES, 2001).

\subsubsection{Practical conditions}

We only found a limited amount of information about practical rearing conditions of pigs in the Philippines.

Above we already noted that in 2015 the number of pigs sold/sow/year was 18.8 and the FCR (Feed Conversion Ratio) was 3.7 (Strak, 2017).

A large pig farm called Cavite Pig City is located just south of Manila. It is among the top farms in the Philippines and embraces US technology to produce its pigs. It has 12.000 sows and raises $65 \%$ of its fattening pigs. It has tunnel ventilation, automated feeding, sow stalls and farrowing crates. It has cast iron slats for farrowing. Cooling is an issue as the environmental temperatures can go up to an average of $34^{\circ} \mathrm{C}$. Cavite Pig City also has older buildings, which are open houses with trees nearby. It has a strict all-in all-out (AIAO) policy; weaning is done at 28 days; finishers are marketed at 165-180 days (up to $130 \mathrm{~kg}$ ). Cavite Pig City is weaning 25 piglets/sow/year (the Philippine average is 20). The ADG is $618 \mathrm{gr}$; FCR: 2.27 (Ter Beek, 2015b).

Backyard pig production is substantial (see above; also Lapus, 2009b). Commercial parties usually consider anything under 100 pigs as backyard, but the government classifies a farm as backyard if it has less than 21 pigs of whatever age. The number of backyard farms is going down (e.g. from about $77 \%$ in 1998 to about $65 \%$ in 2015). Backyard farms typically have temporary, open-sided buildings. Often it has 4 poles, or it could even be a tent. The owners can put down silt, or they can just raise the pigs on the floor with soil. Sometimes they cement the floor and make some drainage. The buildings generally lack stability, with destruction by typhoons being a recurrent problem (Ter Beek, 2015a).

Two YouTube videos are showing pig farming in the Philippines. One shows natural pig farming (AHIW, 2017) and one is referred to as a modern pig housing design (MHD, 2016). The former specifies e.g. dimensions for an open house with natural ventilation and a palm-leaf roof and also a wallowing pool (e.g. at least $1 \mathrm{~m}$ wide). It also mentions mutilations to be conducted soon after birth, including tooth and tail cutting, castration and ear notching. In this more 'natural' system the pigs are weaned at 30 days (AHIW, 2017). The modern design video shows sow stalls and farrowing crates, and also wallowing pools and rooting substrate. The pigs are kept in (traditional) open houses, in buildings with tunnel ventilation, fully slatted floors and very crowded pens (MDH, 2015). Pigs in commercial farms may be provided with a pool in summer, which is cleaned twice a week (Lapus, 2009a).

\subsubsection{Trends}

The pig sector seems to be aware of concerns about pig farming. A pig farmer representative indicated, for example, that " every time we promote pork we hear a lot of complaints. Are we handling the manure properly? Are we treating the animals humanely? Are we following the government regulations on antibiotics or withdrawal? We need to look first into our own backyard." (Ter Beek, 2015a).

\subsection{References}

AHIW (Agribusiness How It Works), 2017. Babuyang Walang Amoy: Profitable Innovative Growing System - Natural Hog Raising Seminar. Youtube. Dec. 22, 2017. Available at https://www.youtube.com/watch?v=9B3eY8C04Y8. Accessed 15-11-2018.

BAFS (Bureau of Agriculture and Fisheries Standards), 2017a. Philippine National Standard (PNS) Code of Good Animal Husbandry Practices for Chickens - Broilers and Layers. PNS/BAFS 184:2016 ICS 65.030.20. BAFS. Okt. 12, 2017. Available at http://www.bafps.da.gov.ph/2017-10-12-0046-55/standard-formulation/philippine-national-standards?download=341: pns-bafs-184-gahpchicken-broilers-layers\&start=180. Accessed 15-11-2018.

BAFS (Bureau of Agriculture and Fisheries Standards), 2017b. Code of Good Animal Husbandry Practice for Swine - Draft copy only. BAFS. Available at 
https://members.wto.org/crnattachments/2017/SPS/PHL/17_2021_00_e.pdf. Accessed 15-112018.

BAI (Bureau of Animal Industry), 2018. Department of Agriculture, BAI. Available at http://www.bai.da.gov.ph/ . Accessed 15-11-2018.

Calderon, J. 2014. Balut - how to eat that fertilized duck egg of the Philippines. CNN. Feb. 7, 2014. Available at https://edition.cnn.com/travel/article/how-to-eat-balut/index.html. Accessed 15-112018

Filipino Poultry, 2016. Layer Farming in the Philippines: Effect of Temperature Step Down. Filipina Poultry. May 22, 2016. Available at http://www.filipinopoultry.com/index.php/category/poultryegg-production-in-the-philippines/. Accessed 15-11-2018.

Gamil, J.T., 2017. Eggs, chicken safe to eat, groups say. Philippine Daily Inquirer. Aug. 17, 2017. http://newsinfo.inquirer.net/923360/eggs-chicken-safe-to-eat-groups-say. Accessed 7-10-2018.

Heaney, L., Meijaard, E., 2017. Sus philippensis (Philippine Warty Pig). The IUCN Red List of Threatened Species 2017. Available at http://www.iucnredlist.org/details/21176/0 and http://dx.doi.org/10.2305/IUCN.UK.2017-3.RLTS.T21176A44139795.en. Accessed at 07-10-2018.

Hirsch, V. 2003. Detailed discussions of legal protections of the domestic chicken in the United States and Europe. Available at https://www.animallaw.info/article/detailed-discussion-legal-protectionsdomestic-chicken-united-states-and-europe. Accessed 6-1-2019.

Jabbar, M.A., 2015. ASEAN Strategic plan of action for the livestock sub-sector 2016-20. Available at https://www.researchgate.net/publication/296831882_ASEAN_Strategic_Plan_of_Action_for_the_ Livestock_Sub-Sector_2016-20. Accessed 25-11-2018.

Lapus, Z.M., 2009a. Swine production in the Philippines (1/2). Pig333. March 24, 2009. Available at https://www.pig333.com/articles/swine-production-in-the-philippines-1-2_854/. Accessed 15-112018.

Lapus, Z.M., 2009b. Swine production in the Philippines (2/2). Pig333. July 9, 2009. Available at https://www.pig333.com/articles/swine-production-in-the-philippines-2-2_1489/. Accessed 15-112018.

Le, T., 2017. Philippine chicken egg layer farm. YouTube. March 17, 2017. Available at https://www.youtube.com/watch?v=Xkiq9qqjrGM. Accessed 15-11-2018.

McDougal, T., 2018. SEA: Growing interest in cage free egg production. Poultry World. Oct. 10, 2018. Available at https://www.poultryworld.net/Eggs/Articles/2018/10/SEA-Growing-interest-in-cagefree-egg-production-344557E/?cmpid=NLC|worldpoultry|2018-1010|SEA:_Growing_interest_in_cage_free_egg_production. Accessed 15-11-2018.

MHD (Modern Home Design), 2015. Piggery House Design In The Philippines. YouTube. Dec. 18, 2016. Available at https://www.youtube.com/watch?v=zpEAFzD7ans. Accessed 15-11-2018.

Molina, M. 2014. The Broiler Chicken Project in the Philippines is fully operational. Nov. 10, 2014. Available at https://siloscordoba.com/blog/new-projects/the-broiler-chicken-project-in-thephilippines-is-fully-operational/ . Accessed 15-11-2018.

PAES, 2000a. Philippine agricultural engineering standard PAES 411:2000 - Agricultural structures Slaughterhouse for swine, small and large animals. Available at https://amtec.uplb.edu.ph/images/downloads/paes/411a.pdf. Accessed 15-11-2018.

PAES, 2000b. Philippine agricultural engineering standard PAES 410:2000 - Agricultural structures Lairage for swine, small, and large animals. Available at https://amtec.uplb.edu.ph/images/downloads/paes/410.pdf. Accessed 15-11-2018.

PAES, 2001. Philippine agricultural engineering standard PAES 401:2001 - Agricultural structures Housing for Swine Production. Available at https://amtec.uplb.edu.ph/images/downloads/paes/401.pdf. Accessed 15-11-2018.

PAWS (Philippine Animal Welfare Society), No date-a. Philippine Animal Welfare Society. Wikipedia. Available athttps://en.wikipedia.org/wiki/Philippine_Animal_Welfare_Society. Accessed 15-112018.

PAWS (Philippines Animal Welfare Society), No date-b. Philippine Animal Welfare Society (PAWS) Frequently asked questions (FAQS). PAWS. Available at http://pawsphilippines.weebly.com/animal-welfare-laws.html. Accessed 15-11-2018.

Phillips, C., 2016. UQ develops ASEAN poultry welfare standards - Good animal husbandry practices are gaining recognition. UQ (University of Queensland), June 29, 2016. Available at https://www.uq.edu.au/news/article/2016/06/uq-develops-asean-poultry-welfare-standards. Accessed 5-12-2018. 
Premier, R., No date-a. ASEAN Good Animal Husbandry Practices for Layers and Broilers - Food Safety Module. ASEAN. Available at http://www.asean.org/storage/images/Community/AEC/AMAF/OtherDocuments/ASEAN\%20Food \%20Safety\%20Module\%20GAHP\%20For\%20Layers\%20and\%20Broilers.pdf. Accessed 15-112018.

Premier, No date-b. ASEAN-Australia Development Cooperation Program Phase II - ASEAN Good animal husbandry practices for layers and broilers - Strategic Plan 2014-2016. ASEAN. Available at http://www.asean.org/storage/images/Community/AEC/AMAF/OtherDocuments/ASEAN\%20Strate gic\%20Plan\%20GAHP\%20for\%20Layers\%20and\%20Broilers\%202014-2016.pdf. Accessed 15-112018.

PSA (Philippine Statistics Authority), 2018a. Selected Statistics on Agriculture 2018. PSA. Available at https://psa.gov.ph/sites/default/files/Selected\%20Statistics\%20on\%20Agriculture\%202018.pdf. Accessed 15-11-2018.

PSA (Philippine Statistics Authority), 2018b. Swine Situation Report, April - June 2018. PSA. Available at https://psa.gov.ph/livestock-poultry-iprs/swine/inventory. Accessed 2-1-2019.

Salas, R.C.D., Orden, E.A., Orden, M.E.M., 2013. Productivity and financial viability of commercial broiler farm using climate controlled system: The case in a State-owned University in Nueva Ecija. 2013 Biennial Convention of PAEDA (Philippine Agricultural Economics and Development Association). Available at https://paedacon.files.wordpress.com/2013/10/fullpaper_salas_ramoncesar.pdf. Accessed 15-112018.

Strak, J., 2017. Swine sector in the Philippines set to grow. Pig Progress. April 21, 2017. Available at http://www.pigprogress.net/Finishers/Articles/2017/4/Swine-sector-in-the-Philippines-set-togrow-123507E/. Accessed 4-1-2018.

Taylor, R., 2013. Growing chickens for egg production in the Philippines. YouTube. July 14, 2013. Available at https://www.youtube.com/watch?v=1sIWUiYaMRc. Accessed 15-11-2018.

Ter Beek, V., 2015a. Changing the mindset of Philippine pig farmers. Pig Progress. Dec. 11, 2015. Available at http://www.pigprogress.net/Home/General/2015/12/Changing-the-mindset-ofPhilippine-pig-farmers-1765591W/. Accessed 15-11-2018.

Ter Beek, V., 2015b. Cavite Pig City: A city within a city. Pig Progress. Dec. 7, 2015. Available at http://www. pigprogress.net/Growing-Finishing/General/2015/9/Cavite-Pig-City-A-city-within-acity-2673896W/. Accessed 15-11-2018.

Tomacruz, S. 2017. FAST FACTS: How much meat does the Filipino consume? Rappler. April 14, 2017. Available at https://www.rappler.com/business/166870-fast-facts-meat-chicken-pork-filipinoconsumption. Accessed 6-1-2019.

USDA Foreign Agricultural Service, 2018. [Query done on 8-11-2018 to retrieve production and trade data from 2016.] Available at https://apps.fas.usda.gov/psdonline/app/index.html\#/app/advQuery. Accessed 8-11-2018.

VACI, No date-b. Philippines. Available at https://vaci.voiceless.org.au/countries/philippines/. Accessed 13-11-2018.

Van Emous, R. In prep. [Poultry sector in Indonesia]. Report Wageningen Livestock Research.

WAP (World Animal Protection), 2014. Philippines. Available at https://api.worldanimalprotection.org/country/philippines. Accessed 21-11-2018.

Wilkins, B., 2017. Increasing Philippines pig meat imports. Pork. May, 2017. Available at https://pork.ahdb.org.uk/prices-stats/news/2017/may/increasing-philippines-pig-meat-imports/. Accessed 15-11-2018. 


\section{Acknowledgements}

Thanks to the Dutch Ministry of Agriculture, Nature and Food Quality (LNV), The Dutch Foreign Agricultural Services, Esther Akkerman, the interviewed contacts and the reviewers. 


\title{
Appendix 1 Questionnaire
}

Below the questionnaire is shown including the invitation that was sent prior to sending the questionnaire itself.

\subsection{Invitation}

For the Dutch ministry of Agriculture I'm presently making inquiries concerning the welfare of poultry and pigs in a small number of countries including [your country]. The background of this research are the upcoming EU trade agreements. We're particularly interested in the main practices of raising poultry (broilers and layers) (and, in case you have any, pigs) in your country, i.e. the types of housing system, esp. in the larger/export-oriented companies, and welfare details of current practices such as commonly used stocking densities, interventions (e.g. beak treatment) and welfare provisions (enrichment/substrate, perches, nest boxes and the like). In addition to common practices we are also interested in legislative or industry requirements and trends/developments concerning (farm) animal welfare in your country, but the latter is not our prime focus.

[Contact name] suggested you might be able/willing help us. If so, I have a survey I could send by email, and/or we could make an appointment to talk it over by phone/skype. Would you be as kind as to have a look at our questionnaire? That would be appreciated greatly.

\subsection{Introduction to the questionnaire}

\author{
Questionnaire Project "Update Animal Welfare in a Global Perspective"
}

Below you find a questionnaire about poultry and/or pig welfare in your country. The questionnaire is rather detailed, to help identify the most important discrepancies with EU welfare practices and regulations. That is also why we have included the main points listed in the EU regulations below as background information.

We are mainly interested in practical housing and management conditions, as well as in welfare regulations/legislation, if any. Please only add company requirements, if any are present/known. Please don't hesitate to skip fields or provide estimates about less familiar topics. Alternatively, we'd appreciate suggestions whom we could contact for further information.

Finally, we find it sometimes works better to have a phone/skype meeting to walk through the questionnaire together. I'd be happy to schedule such a meeting (my contact details are above and below the survey).

Most kind regards,

Marc Bracke 


\subsection{Background information}

Most relevant EU regulations for which we are seeking comparable information:

\section{Laying hens (EC Directive 1999/74/EG)}

At least $750 \mathrm{~cm}^{2}$ space per hen

(Laying) nests present

Litter to scratch and peck at the floor

Perch (at least $15 \mathrm{~cm}$ per hen)

\section{Broilers (EC Directive 2007/43)}

Maximum stocking density $33 \mathrm{~kg} / \mathrm{m}^{2}$ unless the conditions below have been met.

Maximum stocking density $39 \mathrm{~kg} / \mathrm{m}^{2}$, provided:

- Production systems is documented in detail;

- $\mathrm{NH}_{3} \max 20 \mathrm{ppm}$;

- $\mathrm{CO}_{2} \max 3000$ ppm;

- Indoor temperature $\max 3{ }^{\circ} \mathrm{C}$ higher than outdoors when $>30^{\circ} \mathrm{C}$;

- $\quad$ Rel. humidity max $70 \%$ when outdoor temp $<10^{\circ} \mathrm{C}$

Max stocking density $42 \mathrm{~kg} / \mathrm{m}^{2}$, provided:

- $\quad$ if mortality $<(1 \%+(0.06 \% \mathrm{x}$ slaughter age in days $))$

Dry and friable litter on the floor

Light: $>20$ lux, >6u dark

Transport: $1.6-3.0 \mathrm{~kg}$ live weight $160 \mathrm{~cm}^{2} / \mathrm{kg} ; 3.0-5.0 \mathrm{~kg}$ live weight $115 \mathrm{~cm}^{2} / \mathrm{kg}$ (EC Directive No $1 / 2005$ )

Slaughter: stunning before killing (except for religious rites) (EC Directive No 1099/2009)

\section{Pigs (EC Directive 2008/120)}

Free floor space per pig, depending on body weight class (live weight):

- $\quad<=10 \mathrm{~kg}:>=0,15 \mathrm{~m} 2$

- $\quad>10 \mathrm{~kg}-<=20 \mathrm{~kg}:>=0.20 \mathrm{~m} 2$

- $\quad>20 \mathrm{~kg}-<=30 \mathrm{~kg}:>=0.30 \mathrm{~m} 2$

- $\quad>30 \mathrm{~kg}-<=50 \mathrm{~kg}:>=0.40 \mathrm{~m} 2$

- $\quad>50 \mathrm{~kg}-<=85 \mathrm{~kg}:>=0.55 \mathrm{~m} 2$

- $\quad>85 \mathrm{~kg}-<=110 \mathrm{~kg}:>=0.65 \mathrm{~m} 2$

- $\quad>110 \mathrm{~kg}: 1.00 \mathrm{~m} 2$

- $\quad$ Gilt: in group from 4 wk after service $>=1.64 \mathrm{~m}^{2}$;

- Sows: in group from $4 \mathrm{wk}$ after service $>=2.25 \mathrm{~m}^{2} / \mathrm{sow}$

Group housing as of 4 weeks pregnancy

Permanently available proper enrichment material

Castration $<7$ days; no routine tail docking or teeth grinding

Light: 40 Lux at least for a period of $8 \mathrm{hrs}$

Weaning age at least 21-28 days

Transport max $24 \mathrm{~h}$, density < 235kg/m² for pigs 100kg (EC Regulation No 1/2005)

Slaughter: stunning before killing (EC Regulation No 1099/2009)

\subsection{Questionnaire}

\section{LAYERS farm level}

\section{Current Practice Regulations}

\section{1-Housing \& Management}

$\begin{array}{lll}1.1 \text { Housing type (\%) } & 1.1 & 1.1 \\ 1.2 \text { Density (cm }{ }^{2} / \text { hen) } & 1.2 & 1.2 \\ 1.3 \text { Light (intensity and duration) } & 1.3 & 1.3 \\ 1.4 \text { Laying nests }(\%) & 1.4 & 1.4 \\ 1.5 \text { Perch (cm/hen) } & 1.5 & 1.5\end{array}$




\section{2-Enrichment}

2.1 Litter type (exploration and pecking)

\section{3-Mutilations}

3.1 Beak trimming (\%)

3.2 Moulting (\%)

\section{4-Transport \& Slaughter}

4.1 Max transport duration / distance

\section{BROILERS farm level}

1-Housing \& Management system:

1.1 Density (birds $/ \mathrm{m}^{2}$ )

1.2 Maximum growth rate $(\mathrm{g} / \mathrm{d})$

1.3 Bedding type (\%)

\section{2-Enrichment}

2.1 (Day)light (duration, intensity)

\section{3-Transport \& Slaughter}

3.1 Max transport duration / distance

3.2 Transportation system (\% crates/container)

3.3 Slaughter method $(\%)$

3.4 Broken bones (\%)

3.5 Foot pad dermatitis (\%) 
$\%=\%$ of farms:

\section{1-Housing \& Management system:}

$1.1 .1 \mathrm{~m}^{2} / \mathrm{pig}$ for growing-finishing pigs

$1.1 .2 \mathrm{~m}^{2} / \mathrm{pig}$ for weaners,

$1.1 .3 \mathrm{~m}^{2} /$ pig for pregnant sows

$1.1 .4 \mathrm{~m}^{2}$ for farrowing

1.2 Sow group housing (\%, type, duration)

1.3 Light (duration, intensity)

1.4 Weaning age (days)

\section{2-Enrichment:}

2.1 Enrichment? Yes/No; if yes: what type?

\section{3-Mutilations:}

3.1 Castration (\% of males)

3.3 Tail docking (\%)

\section{4-Transport \& Slaughter}

4.1 Max duration of transportation

\section{General on national level}

\section{Current situation}

\section{Future/}

Tendency

\section{National production Pigs:}

1 Numbers ( $\mathrm{n}$ sows, $\mathrm{n}$ grow-finishers/year)

2 Start weight \& end weight of growing-finishing pigs

3 Breeds

4 Import/export

5 Welfare labels

\section{National production Broilers:}

1 Numbers (n broilers/tonnes per year)

2 Slaughter weight

3 Breeds

4 Import/export

5 Welfare Labels

$\begin{array}{ll}1 & 1 \\ 2 & 2 \\ 3 & 3 \\ 4 & 4 \\ 5 & 5\end{array}$

\section{National production Layers:}

1 Numbers (n layers)

2 Eggs produced

3 Breeds

4 Import/export

5 Welfare Labels

$\begin{array}{ll}1 & 1 \\ 2 & 2 \\ 3 & 3 \\ 4 & 4 \\ 5 & 5\end{array}$

\section{Inspection Agency:}

1 Organisation

2 Inspection Frequency

3 Consequences in case of not complying

$\begin{array}{ll}1 & 1 \\ 2 & 2 \\ 3 & 3 \\ 4 & 4 \\ 5 & 5 \\ & \\ 1 & 1 \\ 2 & 2 \\ 3 & 3\end{array}$

\section{Did you consult others?}

If yes which ones? Please provide contact details per sector and if possible underlying documents.

Other remarks, general or per species

Please return this questionnaire to marc.bracke@wur.nl. 


\section{Appendix 2 EU animal welfare regulations}

This annex lists main websites referring to animal welfare regulations in Europe.

Farm animals (Protection of animals kept for farming purposes)

https://ec.europa.eu/food/animals/welfare/practice/farm_en

EC Directive 98/58/EC

http://eur-lex.europa.eu/legal-content/EN/TXT/PDF/?uri=CELEX:31998L0058\&from=EN

Pigs (Minimum standards for the protection of pigs)

https://ec.europa.eu/food/animals/welfare/practice/farm/pigs_en

EC Directive 2008/120/EC

http://eur-lex.europa.eu/legal-content/EN/TXT/PDF/?uri=CELEX:32008L0120\&from=EN

Pigs: Commission Recommendation (EU) 2016/336 regarding tail biting risks

Broilers (Protection of chickens kept for meat production)

https://ec.europa.eu/food/animals/welfare/practice/farm/broilers_en

EC Directive 2007/43/EC

http://eur-lex.europa.eu/legal-content/EN/TXT/PDF/?uri=CELEX:32007L0043\&from=EN

Layers (Minimum standards for the protection of laying hens)

https://ec.europa.eu/food/animals/welfare/practice/farm/laying_hens_en

EC Directive 1999/74/EC

http://eur-lex.europa.eu/legal-content/EN/TXT/PDF/?uri=CELEX:31999L0074\&from=EN

Calves (minimum standards for the protection of calves)

EC Directive 2008/119/EC

https://eur-lex.europa.eu/legal-content/EN/TXT/PDF/?uri=CELEX:32008L0119\&from=EN

Transport (Protection of animals during transport)

https://ec.europa.eu/food/animals/welfare/practice/transport_en

EC Directive No 1/2005 of 22 December 2004

http://eur-lex.europa.eu/legal-content/EN/TXT/PDF/?uri=CELEX:32005R0001\&from=en

Slaughter \& stunning (Protection of animals at the time of killing)

https://ec.europa.eu/food/animals/welfare/practice/slaughter_en

EC Directive No 1099/2009

http://eur-lex.europa.eu/legal-content/EN/TXT/PDF/?uri=CELEX:32009R1099\&from=EN

EFSA page on welfare

https://ec.europa.eu/food/animals/welfare/efsa_opinions_en 


\section{Appendix 3 VACI}

Another NGO animal-welfare ranking is VACI (Voiceless Animal Cruelty Index). It tracks the animal welfare performance of 50 countries selected among the largest producers of farm animal products in the world. The new index complements and makes use of the API (Animal Protection Index, 2014). While the API focused on the quality of animal welfare legislation across countries, the VACI seeks to measure/quantify actual farm animal 'cruelty' (perhaps best read as '(risk for) reduced welfare'), taking into account both production and consumption quantities. As a consequence, for example, the Philippines, which was ranked C in API, ranks A on the VACI index, together with Kenya, India and Tanzania. Mexico, by contrast is scoring poorly (D) on both the API and VACI. Australia scores very poorly (F) on the VACI.

Table. Voiceless Animal Cruelty Index (VACI) ranks for the different countries ((NL: The Netherlands; MX: Mexico; CL: Chile; ID: Indonesia; AU: Australia; NZ: New Zealand; TR: Turkey; PH: Philippines).

\begin{tabular}{|c|c|c|c|c|c|c|c|c|c|}
\hline Item & NL & MX & CL & ID & AU & $\mathbf{N Z}$ & TR & PH & $\begin{array}{l}\text { Global } \\
\text { average }\end{array}$ \\
\hline VACI Overall rank & 39 & 26 & 16 & 9 & 44 & 30 & 33 & 4 & \\
\hline 1. Producing cruelty & 44 & 22 & 19 & 15 & 46 & 37 & 32 & 17 & \\
\hline 2. Consuming cruelty & 46 & 27 & 36 & 5 & 50 & 45 & 21 & 10 & \\
\hline 3. Sanctioning cruelty & 5 & 29 & 9 & 26 & 13 & 3 & 34 & 10 & \\
\hline $\begin{array}{l}\text { 1a. No. of land-based } \\
\text { animals slaughtered per } \\
\text { person/year }\end{array}$ & 36 & 13.3 & 15.4 & 9.3 & 27.2 & 29.3 & 14.8 & 10.2 & 9.7 \\
\hline $\begin{array}{l}\text { 1b. Farm animals per } \\
\text { person }\end{array}$ & 7.3 & 4.9 & 5 & 7.2 & 8.8 & 13 & 4.6 & 2 & 4 \\
\hline $\begin{array}{l}\text { 2a. Percentage of } \\
\text { average diet made up of } \\
\text { land-based animal protein }\end{array}$ & 65.7 & 44.5 & 49.9. & 15.9 & $\begin{array}{l}2^{\text {nd }} \text { highest } \\
\text { (after NL) }\end{array}$ & 56.1 & 32.5 & 30.7 & 35.2 \\
\hline $\begin{array}{l}\text { 2b. Land-based animal } \\
\text { protein consumption per } \\
\text { day }(\mathrm{g})\end{array}$ & 68.8 & 37.6 & 41.9 & 8.4 & $\begin{array}{l}2^{\text {nd }} \text { highest } \\
\text { (after US) }\end{array}$ & 48.2 & 34.6 & 15.5 & 26.7 \\
\hline 3a. API Overall rank & 8 & 25 & 5 & 22 & 10 & 2 & 36 & 16 & \\
\hline
\end{tabular}

Source: https://vaci.voiceless.org.au/. VACI rank: $n$ out of 50 countries ( 1 =best; $50=$ worst). Overall rank is based on 3 sub-ranks: producing (1), consuming (2) and sanctioning (3) cruelty. Sub-ranks 1 and 2 are based mainly on 2 figures listed here as $1 a \& 1 b .$, and $2 a \& 2 b$ respectively. Sub-rank 3 is based on the overall API rank (listed as 3a). Main source of information: FAO.

The VACI is disputable, esp. when the focus is on the welfare (quality of life) of the individual animals. On the other hand, the VACI may rightfully draw the readers' attention to the fact that animal welfare is not just a function of welfare 'intensity' and duration. The numbers of animals (produced, or consumed) should also be taken into account, when welfare is to be assessed overall. 


\section{Appendix 4 Developments regarding free- range eggs in Australia}

In Australia, while battery cages are yet to be banned, there has been a rapid rise in free-range egg production since the early 2000 s, now constituting over $40 \%$ of the shell-egg market. However, since the early 2010s free-range conditions have triggered public controversy from animal rights and consumer groups generating a demand for higher-welfare eggs (Scrinis et al., 2017).

Governments in Australia have consistently defended the interests of large-scale producers in recent decades, and have introduced few welfare regulations. Yet the animal industry-friendly policies at the federal level in Australia have increasingly been challenged (Chen 2016, cited in Scrinis et al., 2017). Producers have resisted legislation, e.g. to ban battery cages. However, some producers have started to meet the demand for higher welfare eggs by diversifying their production systems (Sumner et al. 2011 , cited by Scrinis et al., 2017). Also in response to demands of the 'ethical' food consumer, McDonald's and Aldi, for example, have pledged to only source cage-free eggs (Scrinis et al., 2017), as have Coles and Woolworths (Anon., Pers. comm.).

In the absence of adequate government regulatory standards, consumers come to rely on private certification schemes and labelling. Food labels often emphasize the housing system, and tend to exaggerate or misrepresent the actual production conditions, thereby providing an "ethical halo" (Scrinis et al., 2017).

Government regulation of labelling claims can be important for creating market certainty. The lack of regulation of labelling claims in Australia, in comparison with the EU, may in part account for the 'freerange' labelling controversy in Australia over the past decade (Scrinis et al., 2017).

The Model Codes of Practice for animal welfare are largely non-mandatory standards that are not enforced nor carry penalties for breaches, and in fact may have served to exempt farm animals from animal cruelty laws (Bruce and Faunce, 2017, cited in Scrinis et al., 2017).

When the RSPCA challenged the use of battery cages in the 1990s, the egg sector opposed the ban as well as labelling, and only minor changes were made in the minimum standards $\left(550 \mathrm{~cm}^{2}\right.$ per caged bird instead of 450), and the government did not pursue labelling (Scrinis et al., 2017).

The Model Code of Practice for poultry (PISC, 2002a) specifies an outdoor stocking density of 1500 birds per hectare for free range layers. However, the Code allows for a higher outdoor stocking density if hens are rotated across pastures. This exception is a loop-hole that has been used by large-scale egg producers to justify considerably higher stocking densities, of up to 30.000 birds per hectare (Scrinis et al., 2017).

The Australian Capital Territory (ACT) has passed laws banning caged egg production, however there was at that point only one egg producer in that jurisdiction (Scrinis et al., 2017).

The egg market has bifurcated between battery-cage eggs ( 50\%) and 'free-range' eggs $(\sim 40 \%)$, with barn-laid eggs less than $10 \%$ of the market (AECL 2016, cited in Scrinis et al., 2017). Within free range, two distinct production systems have developed: The first are small-scale free-range egg producers with well-pastured fields and hens typically housed in small and sometimes mobile pens. These eggs often carry either organic/biodynamic certification or one of the few alternative free-range certification logos. The second and dominant type of free-range systems are the very large-scale operations that typically house tens of thousands of hens, and provide chickens 'access' to outdoors through the opening of flaps along the walls of the sheds (Scrinis et al., 2017).

While the mainstream industrial egg producers benefit from the continued use of battery cages, they have also come to embrace this 'industrial free-range' model as a means of capturing the growing market and price premiums for higher-welfare eggs (Scrinis et al., 2017).

The three largest egg processing and distribution corporations-Pace, Sunny Queen and Farm Pridecontrol $60 \%$ of the total egg market, and all three distribute both caged and free-range eggs (Tonkin 2014, cited in Scrinis et al., 2017).

The market for free-range eggs received a significant boost in the early 2010s when the two dominant supermarket chains in Australia-Coles and Woolworths (together controlling $60-80 \%$ of the market)- 
mimicked the British supermarkets by associating their brands with higher animal welfare and quality standards (Scrinis et al., 2017).

Coles and Woolworths have also sought to publicly align themselves with trusted animal advocacy organizations, e.g. highlighting the use of RSPCA-approved products on their websites (Scrinis et al., 2017).

In $2012 \mathrm{AECL}$ suggested allowing up to 20.000 layers per hectare, but this was perceived as misleading and deceptive. The norm proposed by the supermarkets (10.000 layers/ha) became the standard and the Australian government later (e.g. in Queensland in 2013) adopted this norm, while some supermarkets like Coles and Sunny Queen moved on to provide premium free-range eggs with a maximum of 1500 layers/ha (Scrinis et al., 2017).

In Australia, private certification standards and labels have provided assurance to consumers and facilitated the growth of the market for higher-welfare eggs (Scrinis et al., 2017).

In Australia, some intensive producers have exploited the lack of strong regulation by claiming 'free range' status for hens that may rarely venture outdoors, and that has led to ongoing public controversy and political contestation over the meaning of free-range (see e.g. McDougal, 2017b reporting a case of an egg producer having to pay AUS $\$ 300.000$ for making an improper free-range claim).

The Australian government's endorsement of the industrial definition of free-range in 2016 suggests a continuation of 'regulatory capture' of federal governments by the livestock industries (Goodfellow, 2016, cited in Scrinis et al., 2017). (Note that only later, in 2018, a final decision was made to set the free-range limit at 10.000 birds/ha, ACCC, 2018.)

Some animal welfare organizations have also developed their own certification standards and logos, including the RSPCA in Australia.

With very large-scale and intensive operations now supplying much of the barn and free-range eggs in Australia, and without stronger or mandatory regulations of production practices within these systems-such as for indoor and outdoor stocking density or adequate access to hospitable outdoor ranges-the welfare benefits to layer hens resulting from these shifts in housing systems may be limited (Scrinis et al., 2017).

The Australian government has given the green light to standards and rules for certification for the egg producers belonging to Pasture Raised On Open Fields (PROOF) scheme (McDougal, 2017a). It involves unrestricted daytime access to actively managed, pastured range, housing should be as mobile as possible and flock sizes are generally below 2.500 birds. It is hoped this will provide clarity in the dispute regarding 'free range' in Australia (McDougal, 2017a).

After years of public debate the Australian Government specified that the maximum stocking density for free range laying hens may be no more than be 10.000 birds per hectare (McDougal, 2018; ACCC. 2018). 

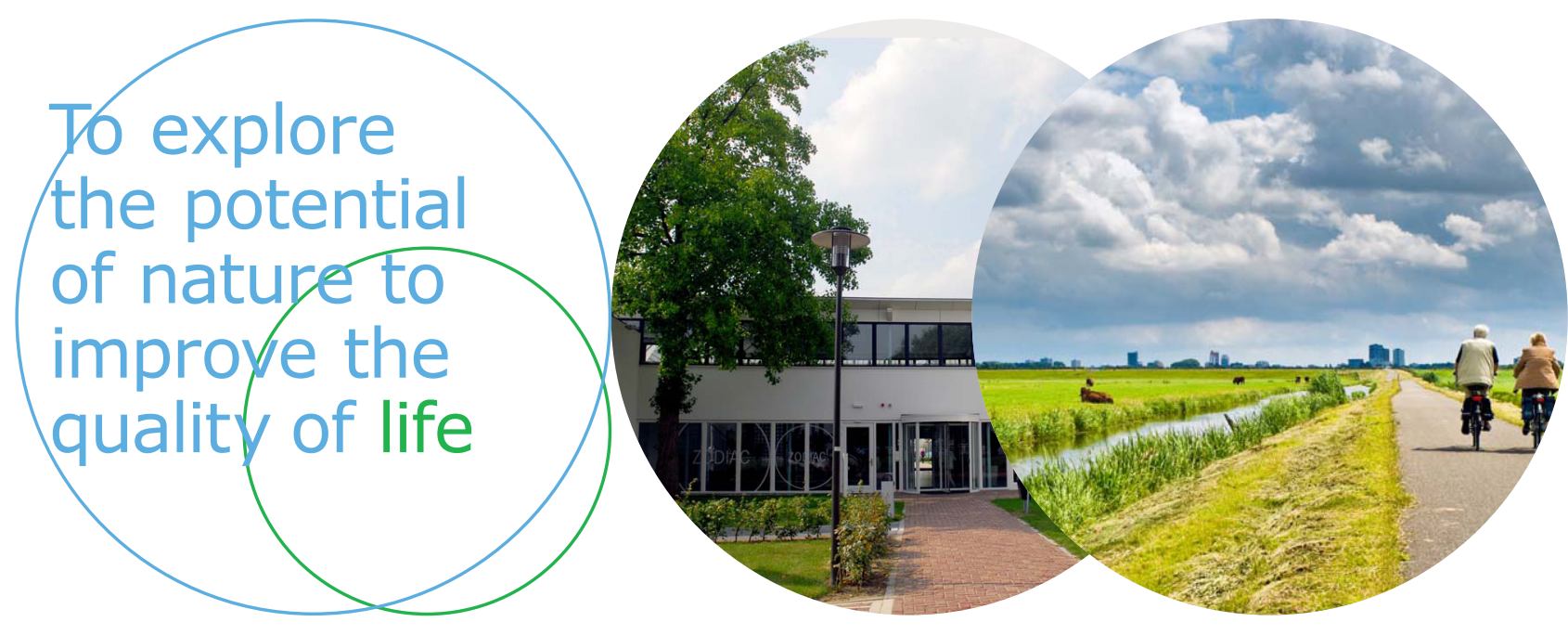

Wageningen Livestock Research P.O. Box 338

6700 AH Wageningen

The Netherlands

T +31 (0)31748 3953

E info.livestockresearch@wur.nl www.wur.nl/livestock-research

Wageningen Livestock Research creates science based solutions for a sustainable and profitable livestock sector. Together with our clients, we integrate scientific knowledge and practical experience to develop livestock concepts for future generations.

Wageningen Livestock Research is part of Wageningen University \& Research. Together we work on the mission: 'To explore the potential of nature to improve the quality of life'. A staff of 6,500 and 10,000 students from over 100 countries are working worldwide in the domain of healthy food and living environment for governments and the business community-at-large. The strength of Wageningen University \& Research lies in its ability to join the forces of specialised research institutes and the university. It also lies in the combined efforts of the various fields of natural and social sciences. This union of expertise leads to scientific breakthroughs that can quickly be put into practice and be incorporated into education. This is the Wageningen Approach. 